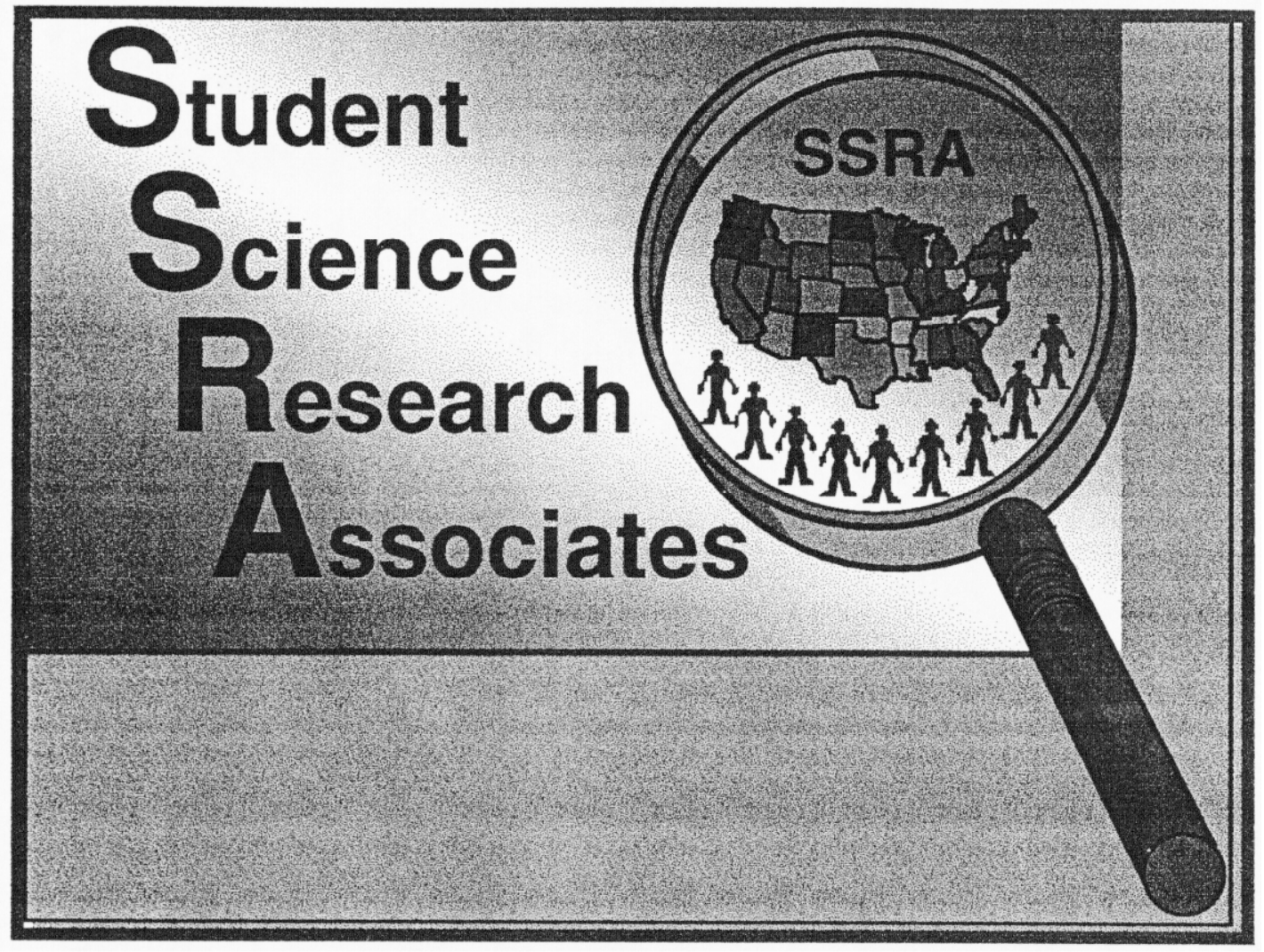

\title{
Student Science Research Associates (SSRA)
}

\author{
Research Journal
}

\section{December 1996}

Lawrence Livermore National Laboratory 


\section{DISCLAIMER}

This document was prepared as an account of work sponsored by an agesey of the United States Government. Neither the United States Government nor the University of Californita nor any of their employees, makes any warranty, express or implied, or sosumes any legal liablitty or responsibility for the sccuracy, completeness, or useful ness of any information, apparatus, prodect, or process disclosed, or represents that its use would not infringe privately owned rights. Reference herelin to any specific commercial products, process, or survice by trade name, tradenarts, manufacturer, or otherwise, does not necessarliy constitute or hapily its eadorsement, recommendation, or favoring by the United States Government or the University of Calffornia. The views and opinions of authors expressed herein do not necessarily state or reflect those of the United States Government or the University of California, and shall not be used for advertising or product endorsement purposes.

This report has been reproduced directly from the best available copy.

Available to DOE and DOE contractors from the Omce of Scientific and Technical Information

P.O. Box 62, Oak Ridge, TN 37831

Prices avallable from (615) 576-8401, FTS 626-8401

Available to the public from the

National Technical Intormation Service

U.S. Department of Commerce

5285 Port Royal Rd,

Springtield, VA 22161

Work performed under the ausplces of the US. Department of Energy by Lawrence Livermore National Laboratory under Contract W-7405-Eng-48. 


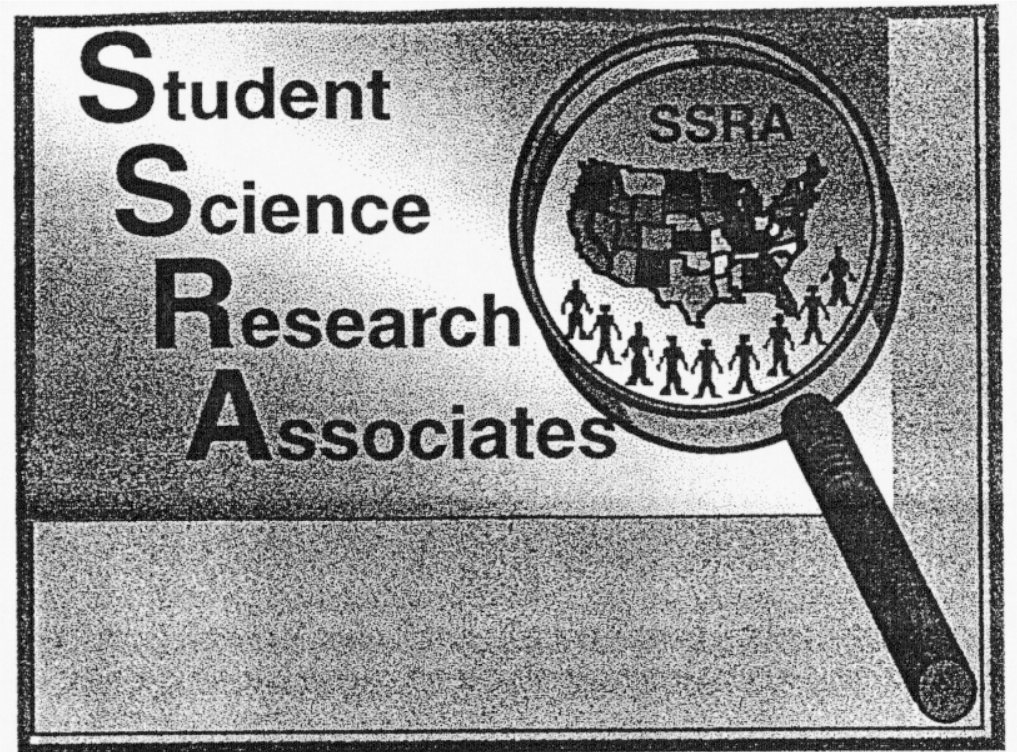

\title{
Student Science Research Associates (SSRA)
}

\author{
Research Journal
}

\section{December 1996}

Edited by: Dr. John Knezovich

Lawrence Livermore National Laboratory 


\section{LAWRENCE LIVERMORE NATIONAL LABORATORY}

The Student Science Research Associates (SSRA) 1996 Research Journal was edited by Dr. John Knezovich, Group Leader for Ecological Response and Restoration, Health and Ecological Assessment Division at LLNL. The SSRA Program was managed by Richard J. Farnsworth. For information concerning this publication, call (510) $422-5059$ or email rfamsworth@ Inl.gov 


\section{Student Science Research Associates (SSRA) \\ 1996 Research Journal}

\section{Lawrence Livermore National Laboratory}

Table of Contents

\section{Hart-Ransom Elementary School}

SSRA Water Research Project

Fourth Grade Students

Page

\section{Vannoy Elementary School}

Various Effects on Polliwogs' Growth and Development:

A Progress Report

Kevin Sien, Carmella Britt, Helen Mirsaeidi, and Donald Becnel

Castro Valley High School

The Effects of Willow Park Golf Course on the Nitrate and Phosphate

Levels in San Leandro Creek

Roderick Bugawan, Lawrence Chiu, and Adam Ow Young

Water Quality Evaluation Using Color Infrared Photography

Mahin F. Arastu

\section{Edison High School}

Biochemical Analysis of Aquatic insects

Kao Vang, Julie Hui, Yia Vang, Johanna Mangahas,

and Monica DeAnda

The Effect of Different Concentrations of Miracid on the Growth

of Stringless Bush Beans

Hanh M. Vo, Kelly J. Tan, Linda Yang, Hoa Pham,

Sopheunn Cheng, and Esmeralda Zendejas

The Effect of Different Concentrations of Calcium Chloride on the Growth of Bush Beans

Vanna Chau.

The Effect of Different Concentrations of Liquid Plant Food on

Stringless Bush Beans

Mai Moua and Sarie Theang.

The Effect of Vegetable Oil on Bean Growth

Sokphorn But, Huon Oeurn, and Srey Prum

The Effect of River Water on Lima Beans

Carolina T. Galvan, Francesca M. Bardo, and Valerie Cuson 


\section{Modesto High School}

Does Storm Water Runoff Alter The $\mathrm{pH}$ and Phosphate

Levels of Dry Creek?

Michael Leonard and JR Hynds.

Is There Acid Rain in Modesto?

San Duch

\section{Tracy High School}

Use of RAPDs (Random Amplified Polymorphic DNA) to Determine Characteristics in Egeria densa

Amar Nijagal

The Effect of Marination on the Formation of Heterocyclic Aromatic Amines in Cooked Chicken Meat

Rita K. Ng. 


\section{SSRA Water Research Project}

Fourth Grade Students

Teachers: Sheryl Chaffey, Mari Gaston, and Pamela Phillips

Hart-Ransom Elementary School

Modesto, CA

What we learned about water

$¥$ Every living thing needs water to survive

$¥$ Three-fourths of the earth is covered with water

$¥ 50-75 \%$ of our body is water

$¥$ Water is made up of two hydrogen and 1 oxygen molecule

$¥$ Water holds heat

$¥$ Animals and plants live in water

$¥$ When water molecules repel molecules of other substances, they don't mix

$¥$ When water molecules attract molecules of other substances, they mix (solubility)

$¥$ The velocity or speed that the water flows affects the animals and plants in and around a river

$¥$ All water has surface tension

$¥$ Water can be a solid, a liquid, or a gas

$¥$ Water is constantly recycling and has been since the beginning of time

\section{Watershed}

$¥$ A watershed is an area of land that drains to a body of water

$¥$ Everything that takes place in a watershed affects the body of water

$¥$ We chose to study the Tuolumne River watershed

$¥$ Things in the Tuolumne River watershed are:

- people

- factories

- homes

- farms

- highways

- schools

- airports

- parks and campsites

- forests

- bridges

- animals

- golf courses

- stores 


\section{Fertilizer}

$¥$ Fertilizer is nutrients: phosphates, potassium, and nitrogen

$¥$ Fertilizer helps plants grow

$¥$ When people fertilize lawns or fields, if not done properly, the fertilizer can be washed into the river by sprinklers, rain, or melting snow

$¥$ If too much fertilizer gets into the river, the algae will grow and grow and eventually cause the fish to die

What we learned about algae

$¥$ Algae are green water plants; any of a large group of mostly aquatic organisms that contain chlorophyll. Through the process of photosynthesis, algae produce most of the oxygen and food in water

$¥$ Algae produce oxygen in the day and use it at night

$¥$ If the plants grow too much they will take oxygen from the fish at night

\section{Pollution}

$¥$ Pollution is anything that harms the water

$¥$ Pollution can hurt people and aquatic animals and plants

$¥$ Not everything you see in the water is polluting the water

$¥$ Some things that you cannot see in the water are actually polluting the water

$¥$ If there is only a very small amount of a poilutant in a large amount of water, it may not be harmful

$¥$ Point source pollution is when you can see the exact point that pollution is going into the water (e.g., a sewage pipe)

$¥$ Nonpoint source pollution is when pollutants are washed or blown into the river from an unknown point

\# Nonpoint source pollution is usually carried by storm water or melting snow runoff

\section{Best management practices}

$¥$ Best management practices are things people can do to prevent nonpoint source pollution

¥ Some best management practices are:

fix and maintain cars so that they do not leak oil and gasoline

- plant grass, trees, and shrubs to hold soil and prevent erosion

- build dams or berms near plowed fields

- fence in pastures

- don't over fertilize

- avoid fertilizing before a rainstorm

\section{Technology}

$¥$ use e-mail to communicate with mentor scientists at LLNL

$¥$ use e-mail to correspond with other classes working on similar projects

$¥$ explored the internet

$¥$ use e-mail to communicate our results 
What we learned about water quality testing

$¥ \mathrm{pH}$ has a scale from $1-14$ and tells us how acidic or basic the water is

$¥ 7$ is neutral, below 7 is more acidic, above 7 is more basic

$¥ \mathrm{~A} \mathrm{pH}$ of $5.5-9.5$ is ideal for fish

$¥$ D.O. means dissolved oxygen and is the amount of oxygen that is dissolved in the water

$¥$ Fish need a D.O. of from 9-11

$¥$ When we tested at the river, the D.O. was 9.7

$¥$ Temperature is how warm the water is

$¥$ When we tested at the river, the temperature was 15.3 degrees Celsius

$¥$ Velocity is the speed the water flows (v=distance over time)

$¥$ The velocity of the Tuolumne River water was 1.3 feet per second

$¥$ Turbidity is the cloudiness of the water

$¥$ When you observe water, you look at it and you smell it

$¥$ When getting water samples, always stand downstream

$¥$ Many things you do can contaminate your water samples (not using gloves, using plastic instead of glass bottles, using contaminated containers...)

Deciding on our "big question"

¥ The fourth grade classes went to the river with five scientists from Lawrence Livermore National Laboratory

$¥$ The scientists taught us how to do water quality tests ( $\mathrm{pH}$, dissolved oxygen, temperature, and velocity)

¥ The scientists taught us about surface tension, solubility, and lots more

$¥$ We tallied the many forms of pollution found at the river

$¥$ After returning to class, we graphed the different kinds of pollution

$¥$ We learned a lot about point source and nonpoint source pollution from the enviroscape model

$¥$ We realized that lots of what we do in our watershed affects the river (i.e., over fertilizing our lawns right before a rain, allowing our cars to leak oil, allowing cows access to the river)

$¥$ We reviewed pictures of the Tuolumne River taken after the winter rains and saw homes with lawns which might cause nonpoint source pollution if not fertilized properly

$¥$ Thus, we chose to study the effect fertilizer has on the Tuolumne River water

$¥$ Dr. Knezovich came to our classrooms and helped us design our project 


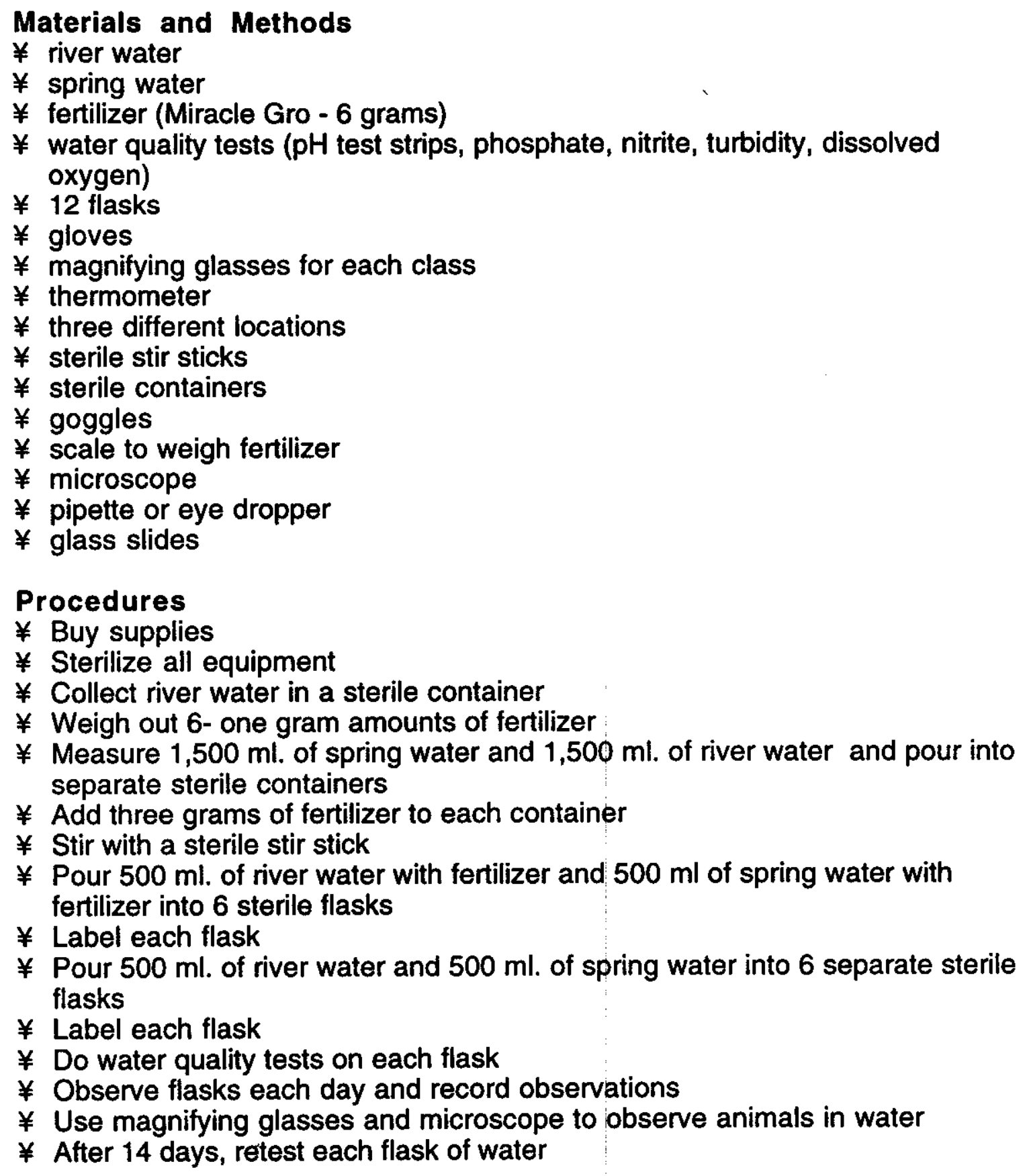




\section{Beginning observartions at all locations}

$¥ \quad$ Spring water at beginning

- clearest of all four

- no turbidity

- best to drink

- nothing on the bottom

$¥ \quad$ Spring water with fertilizer at beginning

_ transparent

- blue-green color

_ nothing on the bottom

$¥ \quad$ River water at beginning

- cloudy

- brownish/tannish in color

- brown silt on the bottom

- a few glittery specks on the bottom

_ did not look good to drink

$¥ \quad$ River water with fertilizer at beginning

- cloudy

- brownish/tannish in color

- brownish/green silt on the bottom

_ did not look good to drink

Observations - Mrs.. Gaston's class (dark location)

$¥$ Spring water

- still clear

_ fresh smelling

- evaporated the most

$¥$ Spring water with fertilizer

- had a little bit of stuff on bottom of the flask

- water was blue and smelled fresher than river water

* Tuolumne River water

- had brown stuff on the bottom of the flask (algae?) that looked like worms

- smelled fishy

- water color was lighter than river water with fertilizer

$¥$ Tuolumne River water with fertilizer

_ smelled fishy

- the most turbid water although less turbid than the beginning

- had green stuff on bottom that looked like worms 
Ending observations of Mrs. Chaffey's class

(sunny location)

$¥$ Spring water

- remained clearest

- smelled fine

looked the cleanest

\# Spring water with fertilizer

_ turbidity increased

- blue color lightened

- had a white sediment on the bottom

\# River water

- turbidity decreased

- brown silk clumped on the bottom

- a little critter was observed swimming in the water

- number of critters increased as days passed

$¥$ River water with fertilizer

- turbidity decreased

_ algae increased with time

- algae got greener and greener each day

- two different types of critters were observed

- the number of critters increased as the days passed

Ending observations of Mrs. Phillip's class (shady location)

$¥$ Spring water

- clear

- clean flask bottom

- $\mathrm{O}_{2}$ bubbles on side

¥ Spring water with fertilizer

- a little lighter, but still blue-green

- slightly cloudy

$¥$ River water

clean flask bottom

_ less tannish and turbid

- brown silt has trenches in it

- critters swam from silt to top of water

- oval shaped light colored critters increased

$¥$ River water with fertilizer

- greener and less turbid

- brownish-green silt has trenches

- oval shaped light colored critters increased

2 brown 1/4" long critters would squirm and then glide 


\section{Conclusions}

$¥$ When water is not disturbed, silt and dirt will settle to the bottom and the water will become less turbid

$¥$ There is a direct correlation between the amount of light and the amount of algae that grew in our flasks

$¥$ Fertilizer itself does not harm aquatic life, but it does increase the amount of algae that grew in our flasks

\section{Further studies}

$¥$ Investigate the cause of the nitrite levels rising rather than dropping in river water with Miracle Gro

$¥$ Study the effects water critters had on our project

$¥$ Investigate the rate of evaporation as it relates to particles in water

$¥$ Research the relationship between the amount of water and the growth of algae

$¥$ Discover if aquatic life would be present in water if it was in the dark for one week and then in the sun for one week

\section{DISSOLVED OXYGEN}

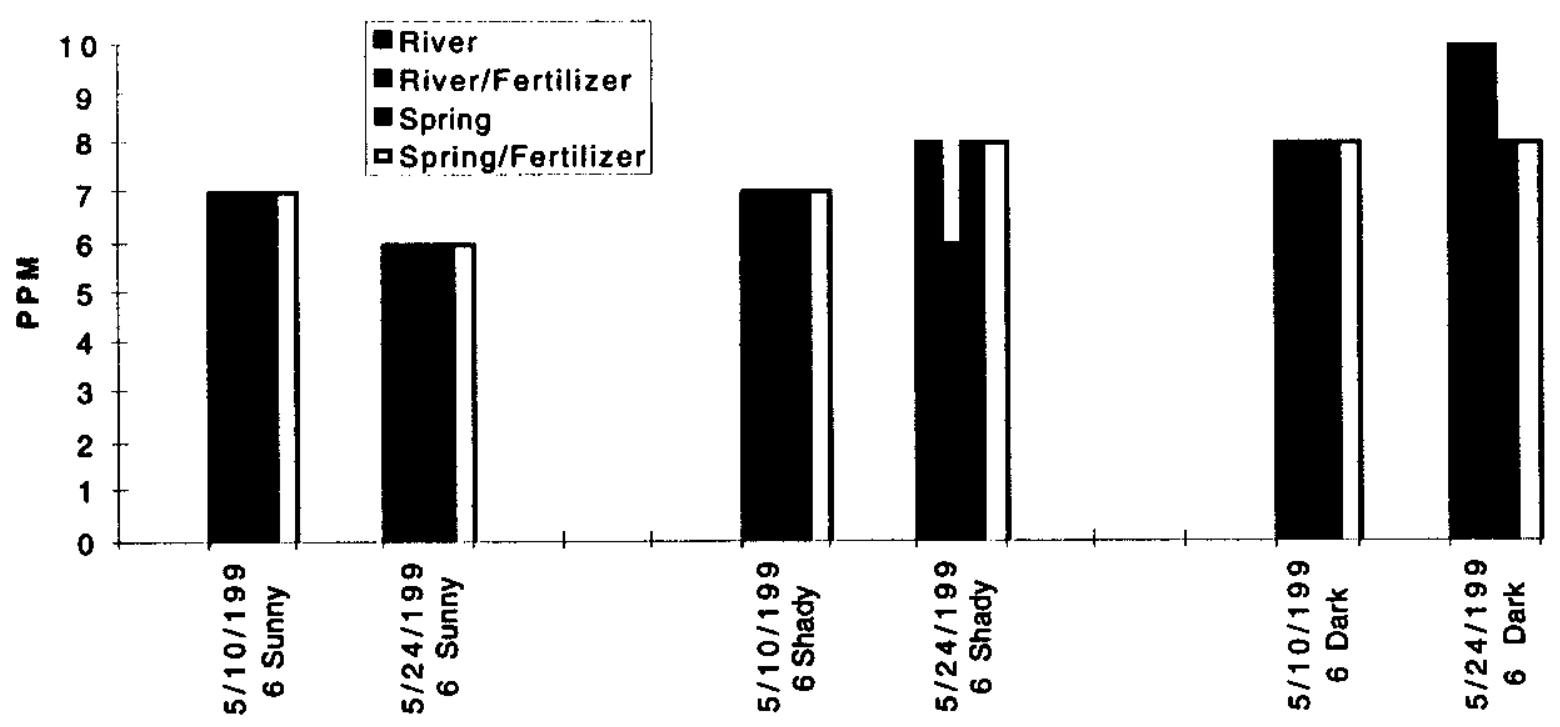

DATES \& AREAS 


\section{NITRITE}
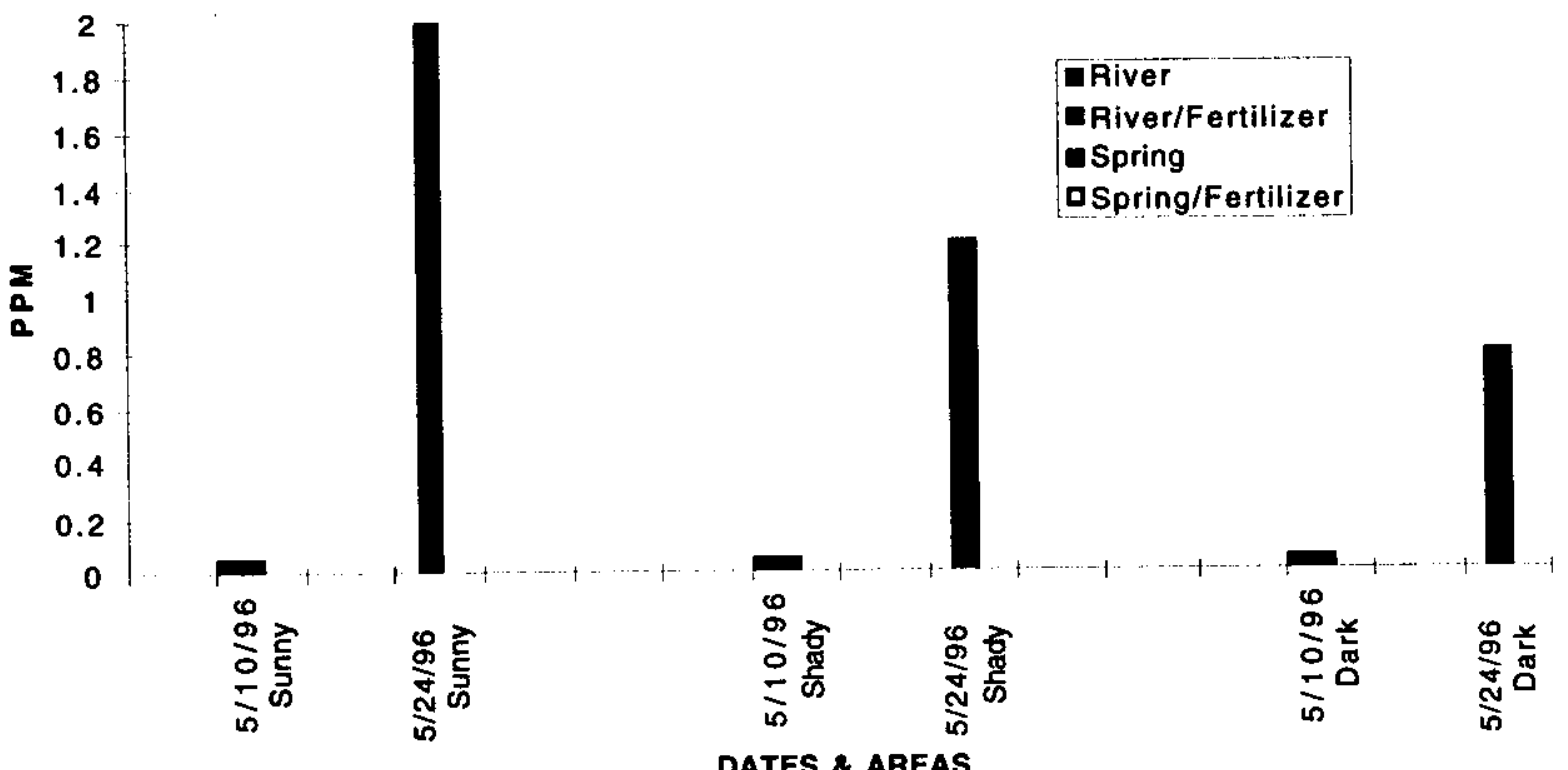

pH

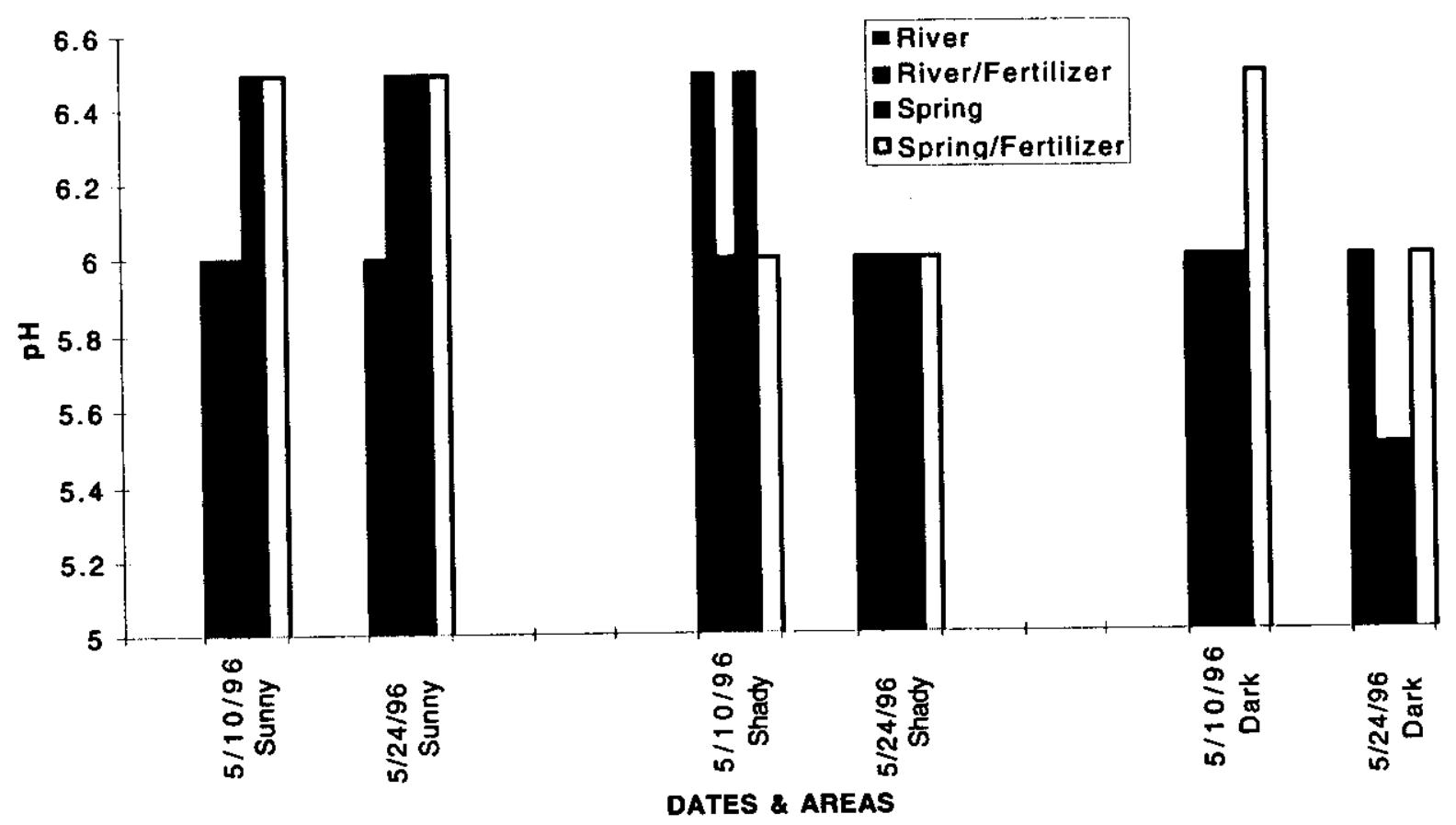


PHOSPHATE

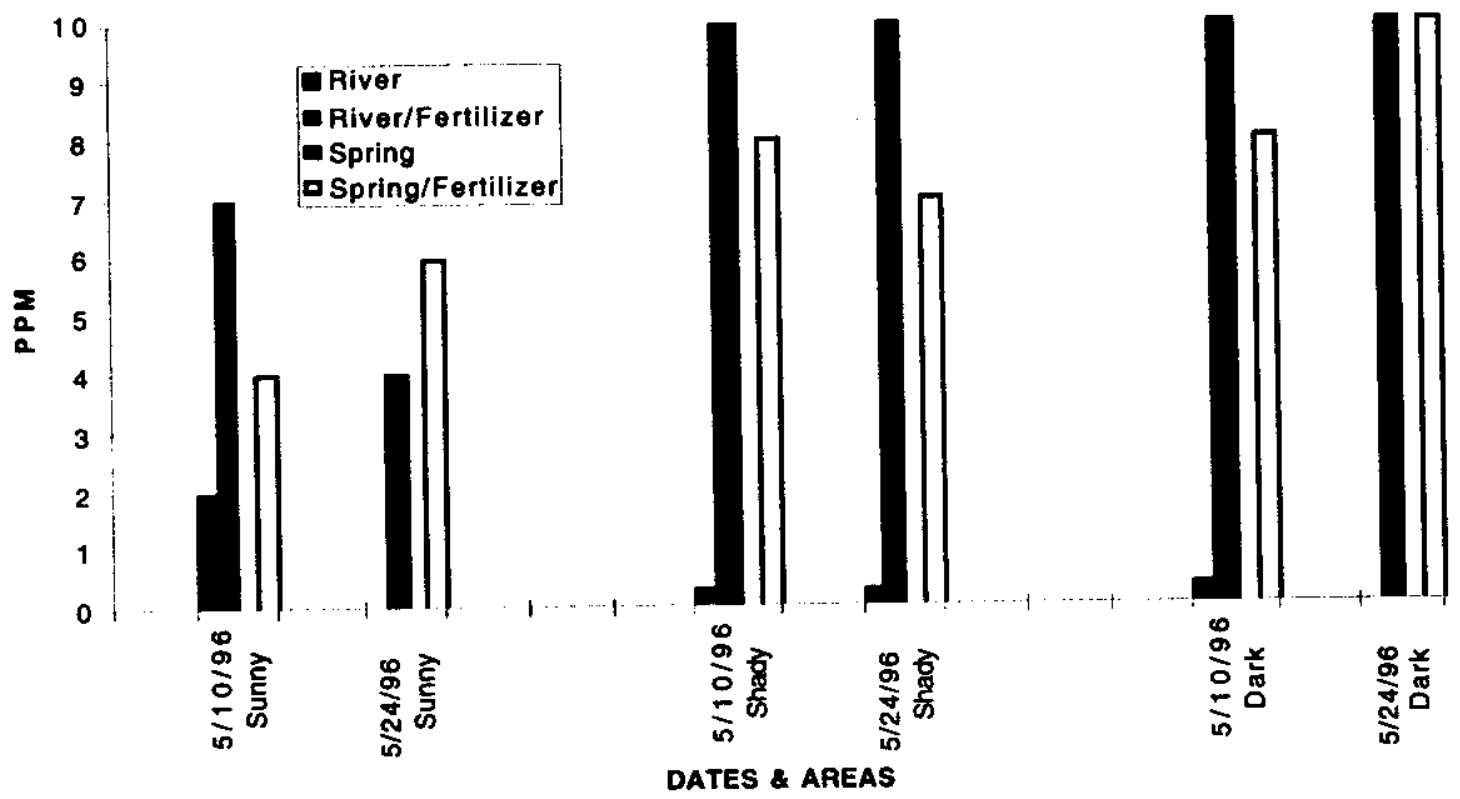

Turbidity

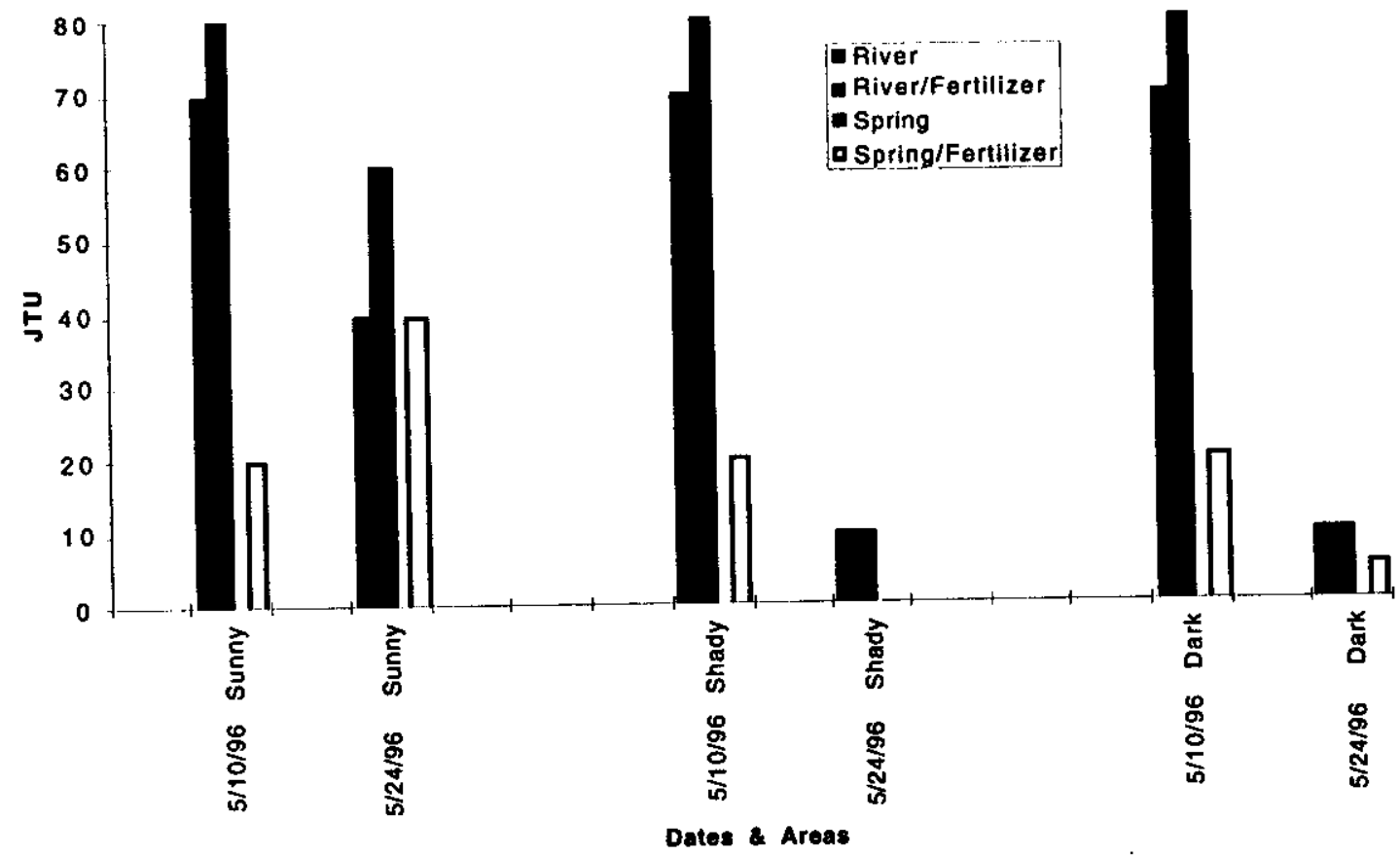


Various Effects on Polliwogs' Growth and Development: A Progress Report

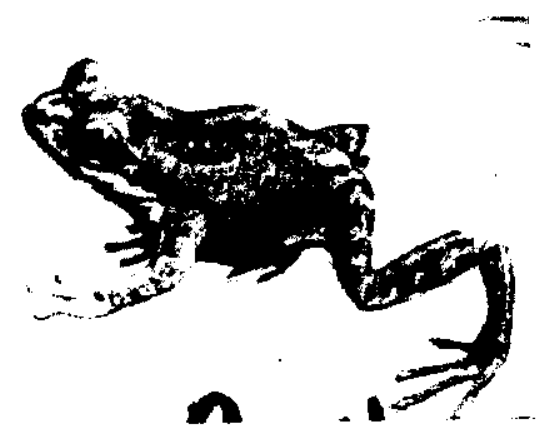

Kevin Sien, Carmella Britt, Helen Mirsaeidi, and Donald Becnel Teacher: Susie Bellone

\section{Vannoy Elementary School} Castro Valley, CA

Research Question: Will the size of the container affect the size of the polliwog?

\section{Materials and Methods}

Students brought in a glass jar and filled it with:

1. $100 \mathrm{ml}$ of pebbles $(50 \mathrm{ml}$ if small jar)

2. Tap water that had been left standing $\mathbf{4 8}$ hours.

3. A piece of seaweed

4. A polliwog - all polliwogs came from the same spawn.

\section{Results}

\begin{tabular}{|c|l|c|c|c|}
\hline Week & Jar Size & No Growth & $\begin{array}{c}\text { Some } \\
\text { Growth }\end{array}$ & Died \\
\hline April 29 & Small (8) & 4 & 2 & 2 \\
& Medium (9) & 0 & 8 & 1 \\
& Large (12) & 3 & 9 & 0 \\
\hline 2 & Small (7) & 2 & 5 & 0 \\
May 6 & Medium (10) & 0 & 7 & 3 \\
& Large (12) & 3 & 8 & 1 \\
\hline \multirow{2}{*}{4} & Small (5) & 0 & 2 & 3 \\
May 20 & Medium (10) & 0 & 7 & 3 \\
& Large (12) & 0 & 10 & 2 \\
\hline
\end{tabular}


Week 1 - April 29, 1996
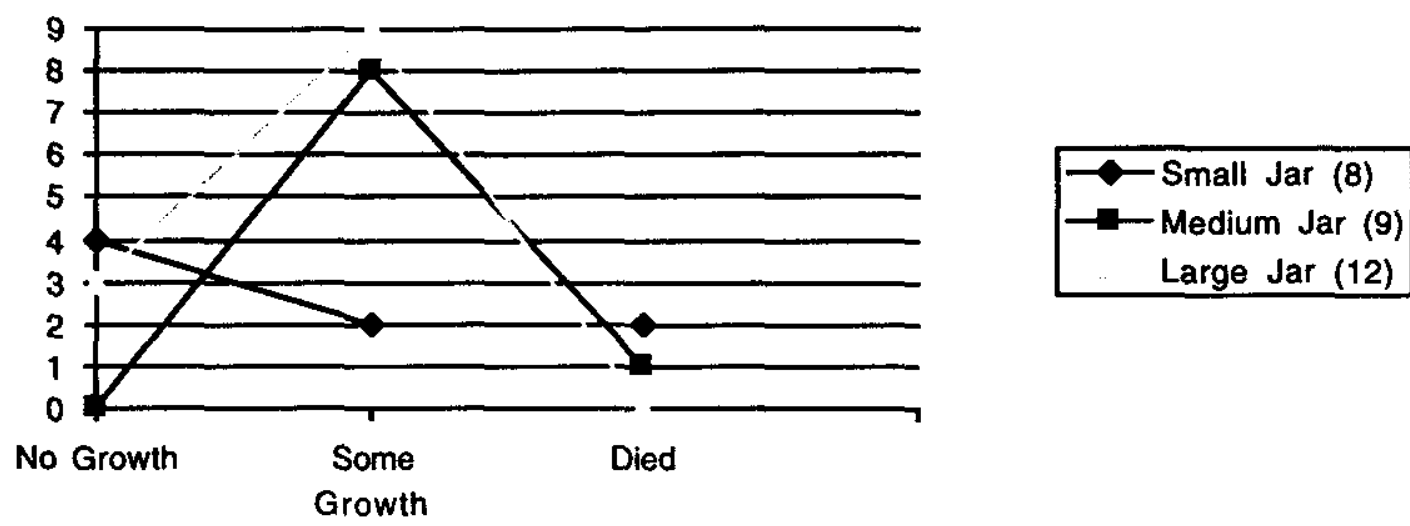

Week 2 - May 6, 1996
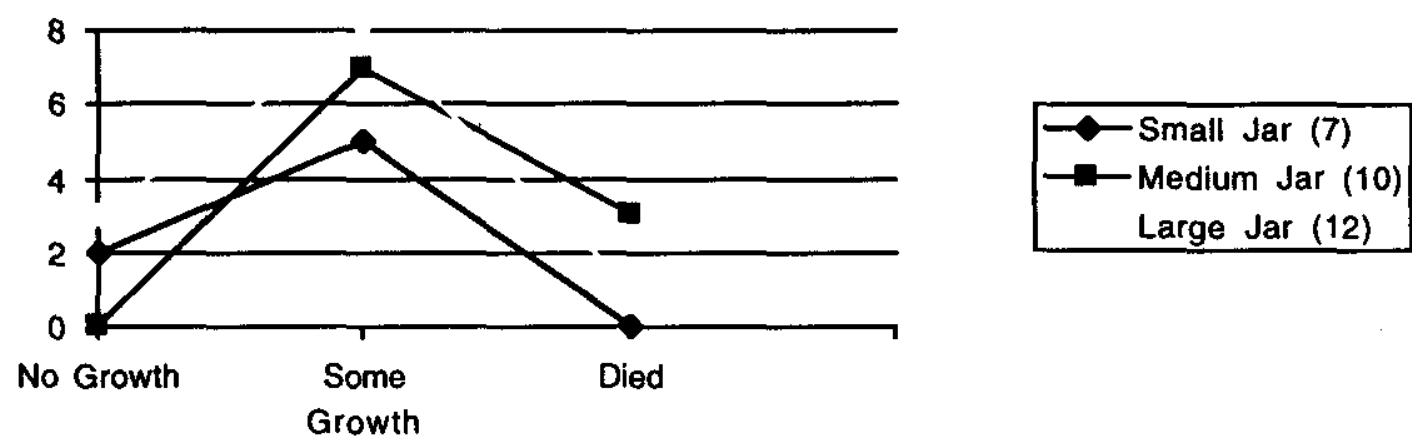

Week 4 - May 20, 1996
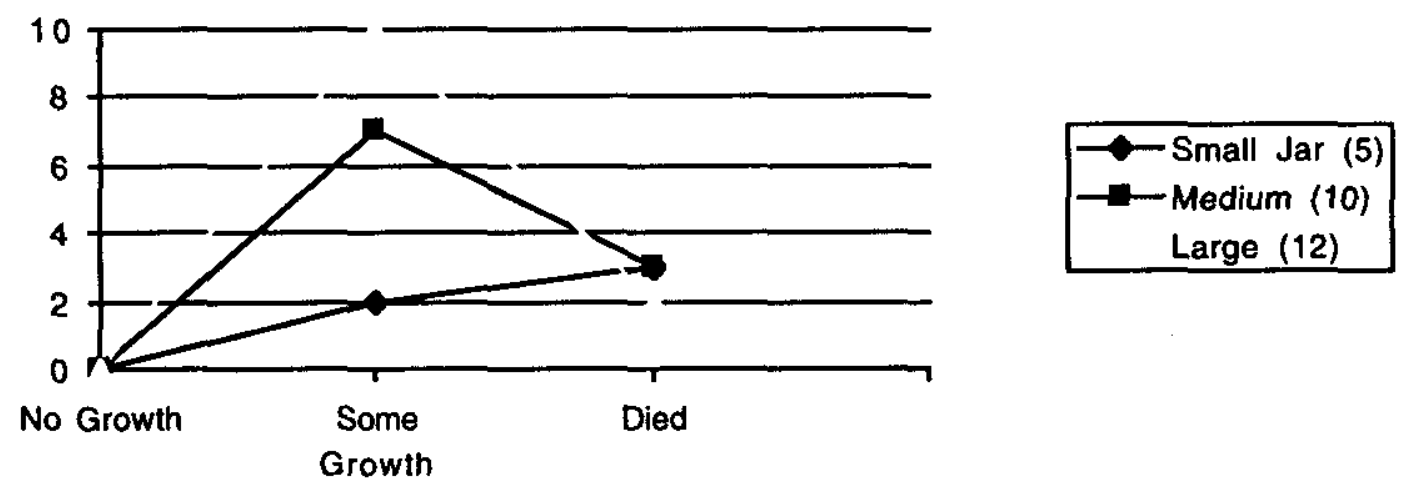


\section{Conclusions}

1. Polliwogs in medium and large jars have a better chance of survival.

2. Some polliwogs did die in large jars.

3. More polliwogs died in small jars.

4. It was difficult to investigate polliwog growth when the polliwogs kept dying.

\section{Variables Affecting Polliwog Growth}

What are the variables in the aquatic environments that could affect polliwog health?

1. Toxic chemicals in the tap water

2. Polliwog wasn't healthy to begin with

3. Temperature change

4. Jars not completely clean in beginning

5. Plant and polliwog need more sunlight than in room

6. Polliwogs might not have right food

7. Not enough dissolved oxygen (D.O.) in water

8. Shock of going from large to small environment

9. Pollution in jar (added after April 23)

\section{Possible Experiments}

1. For variable \#1, could compare polliwog in pond water, distilled water, tap water - all other conditions the same

2. For variable \#6, could try different foods (algae), - all other conditions the same.

3. For variable \#7, test dissolved oxygen in a small, medium, large jar weekly all other conditions same.

4. For variable \#5, put jars near sunlight, far from sunlight - all other conditions the same.

\section{Does Water Surface Area Affect Dissolved water content?} Procedure:

Place $250 \mathrm{ml}$ of water into a small, medium and large jar.

Test D.O. content, record.

Test D.O. content again after 1,2 , and 3 weeks. 


\begin{tabular}{|l|l|}
\hline Date & \multicolumn{1}{|c|}{ Dissolved Oxygen } \\
\hline & $\begin{array}{l}\text { Small jar } \\
\text { Medium jar } \\
\text { Large jar }\end{array}$ \\
\hline & $\begin{array}{l}\text { Small jar } \\
\text { Medium jar } \\
\text { Large jar }\end{array}$ \\
\hline & $\begin{array}{l}\text { Small jar } \\
\text { Medium jar } \\
\text { Large jar }\end{array}$ \\
\hline & $\begin{array}{l}\text { Small jar } \\
\text { Medium jar } \\
\text { Large jar }\end{array}$ \\
\hline
\end{tabular}




\title{
The Effects of Willow Park Golf Course on the Nitrate and Phosphate Levels in San Leandro Creek
}

\author{
Roderick Bugawan, Lawrence Chiu, and Adam Ow Young \\ Teacher: John Petersen \\ Castro Valley High School \\ Castro Valley, CA
}

\begin{abstract}
Our experiment studied the effects of the Willow Park Golf Course on the nitrite and phosphate levels on San Leandro Creek. We tested 2 sites, one above the golf course and one below the golf course. We sampled the creek, testing for $\mathrm{pH}$, temperature, dissolved oxygen, nitrite and phosphate. We are especially interested with nitrites and phosphates because they are in certain fertilizers.
\end{abstract}

\section{Purpose}

The purpose of our research was to observe the human impact on the nitrite and phosphate levels in San Leandro Creek. The source of human impact we encountered was Willow Park Golf Course. We think that golf courses use fertilizers that contain certain chemicals which we believe will affect the nitrite and phosphate levels in San Leandro Creek. In addition, our null hypothesis states that the golf course will not affect the levels of nitrites and phosphates in the San Leandro Creek.

We are testing the levels of nitrite and phosphate because they have been known to promote algal bloom. Algal bloom is detrimental to the living organisms that live in the water and require oxygen. We believe that runoff from the golf course will promote this algal bloom.

\section{Materials and Methods}

- Thermometer

- Nitrite snap kit

- Phosphate snap kit

- Dissolved oxygen snap kit

- $\mathrm{pH}$ paper

- Gloves

- Boots

To determine the water temperature, we inserted the thermometer roughly two inches below the surface of the water.

In order to test for nitrite, we filled a capsule with five milliliters of the water being sampled and inserted a CHEMet snap tube which we then snapped. We then waited for ten minutes, for the full color development, to determine the nitrite levels in the water.

We determined the phosphate level by filling another capsule with five milliliters of the water being sampled. Then we added one drop of activator solution to 
the capsule, covered it, and shook it vigorously. Next we dipped the CHEMet snap kit into the capsule and broke the tip. We then waited two minutes, for full color development, and determined the phosphate levels.

We gathered the results from dissolved oxygen by inserting the CHEMet snap test into the creek and broke the tip. After waiting two minutes, the full color development helped us determine the levels of dissolved oxygen in the creek.

$\mathrm{pH}$ paper was used to calculate the $\mathrm{pH}$ levels in the creek. It was determined by placing the $\mathrm{pH}$ paper into the creek. We then removed it. Afterwards it was compared to a chart that gave us the final results.

Gloves and boots were used to keep us clean! Also, the gloves were used to keep the water uncontaminated.

\section{Observations}

During our months of observation we noted many environmental changes in the creek. On December 22, 1994, we noted that there was no water present on our section of the creek. On December 27, 1994, we again noted that there was no water in the creek.

On January, 16 1995, we found that water was present, although there was very minimal amount of water. We started our initial testing on this date. We were barely able to finish our testing below the golf course because the owner of Willow Park Golf Course would not allow us to test the water. This created great difficulties for us because we needed to find another site to test below the golf course. On February 20,1995, we were only able to test above the golf course because the owner would not let us test again.

On March 19, 1995, we were able to find an alternative testing site, below the golf course. The site was located under a bridge, off Cameron Loop. This is the site where we continued to test from then on. On April 2, 1995, we observed that the water level in the creek was unusually high. On April 9, 1995, we observed that the water level in the creek decreased a great deal. Evidently the workers of Lake Chabot Park released a massive flow of water. It is also evident that the these workers are responsible for the decrease of water.

\section{Conclusions}

The purpose of our project was to see if the Willow Park Golf Course had a significant impact on the nitrite and phosphate levels in San Leandro Creek. Our null hypothesis for our testing time period was correct. There was little or no change in the amounts of nitrite and phosphate above and below the golf course.

We learned many things during the course of our testing. We learned what nitrites and phosphates are. We also learned that the Willow Park Golf Course does not affect the amounts of nitrite and phosphates in the water. We also learned that there are some people who would not let us test on the creek 
because they were afraid that we might find something that could get them in trouble.

There are a few problems we have run into during the course of our research. On problem is that there was no water present in our creek until January. Another problem was that the owner of Willow Park Golf Course would not allow us to test on his property. Thus, we had to find an alternative spot to test. This was a very interesting experiment, and hopefully other groups will continue our research.

\section{Social action}

On May 9, our group planted willow trees in the San Leandro creek for the creek rehabilitation program. In addition, we communicated our results to EMBUD. 


\title{
Water Quality Evaluation Using Color Infrared Photography
}

\author{
Mahin F. Arastu \\ Teacher: John Petersen \\ Castro Valley High School \\ Castro Valley, CA
}

Castro Valley High School is a growing school of about 1700 students located in the heart of Castro Valley. This school is academically based and is striving for the growing advancement of science and technology along with its curriculum. The research whose results are reported here was done in 1995.

\section{Introduction}

Dammed and diverted, disputed and polluted, water is an asset we can no longer take for granted. Like good health, we ignore water when we have it. But, like health, when water is threatened, it's the only thing that matters. Fresh water is the blood of our land, the nourishment of our forests and crops, the blue and shining beauty at the heart of our landscape. Where there is no water, there is no life. Today, with the industrial revolution and population growth, maintaining good water quality is a big concern. We are trying a new method involving infrared photography that we think might help our understanding of water quality evaluation a liftle better. Hopefully, color infrared photography will show us something new that has not been researched before.

\section{Research Objectives}

The purpose of this research is to determine if color infrared photography can be used to evaluate the effects of pollution on water quality. It is recognized that during a school year project, the time available is not usually enough to make a conclusive study. However, it is hoped that the first-of-its-kind research reported in this paper will form the basis of further work in this interesting and exciting field.

\section{Materials and Methods}

The materials used and the procedure adapted during this research are given below:

\section{Materials Used during the Infrared Photography Session}

1. Nikon FE $35 \mathrm{~mm}$ SLR camera

2. mm Nikon Al lens

3. Nikon E zoom lens

4. Nikon Zoom Touch 400 AF camera with $35-70 \mathrm{~mm}$ lens

5. Wratten Gelatin \#2 filter (kit with cleaning cloth)

6. Slik U212 Universal tripod

7. Kodak Ektachrome Infrared Film

8. Thermometer

9. Remote shutter release 
10. Cellotape (to tape filter on lens)

11. Kodak Gold Kodacolor Print film (200 ASA film speed)

\section{Procedure}

At the onset, it was important to choose the four sites in the Castro Valley area for the evaluation of the infrared technique. They were chosen from (what I believed to be) the least polluted to the most polluted, from the start of the river, and its passage through the polluted environment. To prepare for the project, handouts and books were read on background information about water pollution and color infrared photography. These documents are listed clearly in the references. After the review of all the references, charts were prepared for the data that was being recorded as well as for the observations.

The actual infrared photographs were taken on April 22, 1995. It lasted throughout the day from 11 AM that morning to 4 PM in the afternoon. The atmospheric temperature was about $24 \mathrm{C}$ and the water temperature was about 21C. It was a warm and sunny day with very clear skies - ideal for infrared photography.

The pictures were broken down into three categories: water only; vegetation only; water and vegetation. For every one of the four sites, we took about 3-4 pictures in each of the categories above as recommended in the Kodak instruction booklet for the use of the infrared film. A tripod was used for avoiding camera shake and keeping the pictures steady. All photos were taken in daylight except in a few cases where there were dark spots due to the vegetation. Flash was not used in any of the photographs. For every picture, exposures were bracketed. This is because for infrared film, the specification of the exact film speed is not usually available. Kodak recommends bracketing the exposure and using 100 ASA as the nominal film speed. Before each picture, the camera's exposure meter was set for camera settings without a filter for 100 ASA. For every picture the data recorded was the F-number, site number, exposure number, and shutter speed. Also, in a separate section, all the site observations were written. For example, the names of the vegetation around the streams and the water depth.

For every infrared photograph taken, a corresponding regular color photo (that uses the visible part of the spectrum) was also taken. This was done so that the infrared and regular photos could be compared and the effect of infrared photography evaluated.

Data collection and analysis The data in table 1 is taken from the document "Kodak Infrared Films" (Reference 10). It shows the expected colors on infrared photographs of various subjects, such as muddy water, silted water, etc. 
Table 1. Representative modified color renditions

\begin{tabular}{|l|l|}
\hline \multicolumn{2}{|l|}{} \\
\hline Muddy water & Lighter tones \\
\hline Brownish, silted water & Green \\
\hline Clear water & Black \\
\hline Water suffused with algae & Red \\
\hline Water with low dissolved oxygen & Milky \\
\hline Healthy, deciduous, green foliage & Red, Magenta \\
\hline Diseased or deficient foliage & Greenish, Bluish \\
\hline Badly stressed foliage & Yellow \\
\hline Conifers & Dark purple \\
\hline Evergreens & Red-brown \\
\hline Some blue flowers & Yellow \\
\hline Red rose & Yellow \\
\hline Fluorite crystal & Buff \\
\hline Dolomite limestone & Gray-brown \\
\hline Some green pigments & Purple \\
\hline Blue sky & Sky blue \\
\hline Sooty mold on plants & Black \\
\hline
\end{tabular}

Description of Site 5 and camera settings for infrared photography : This site was at a bridge. The first three pictures were taken from under the bridge. The rest of the photographs were taken from on top of the bridge. There was a lot of vegetation on the side of the stream. The names of the dominant vegetation are: Alder, Willow, Box Elder, Cotton Wood, Rubrua- Wild berries, Nettle, and some Poison Oak. This site was in a partially sunny area. The water depth was about 12 inches. This site is located along Redwood Road in Castro Valley. It is in a rural area somewhat away from the city. 


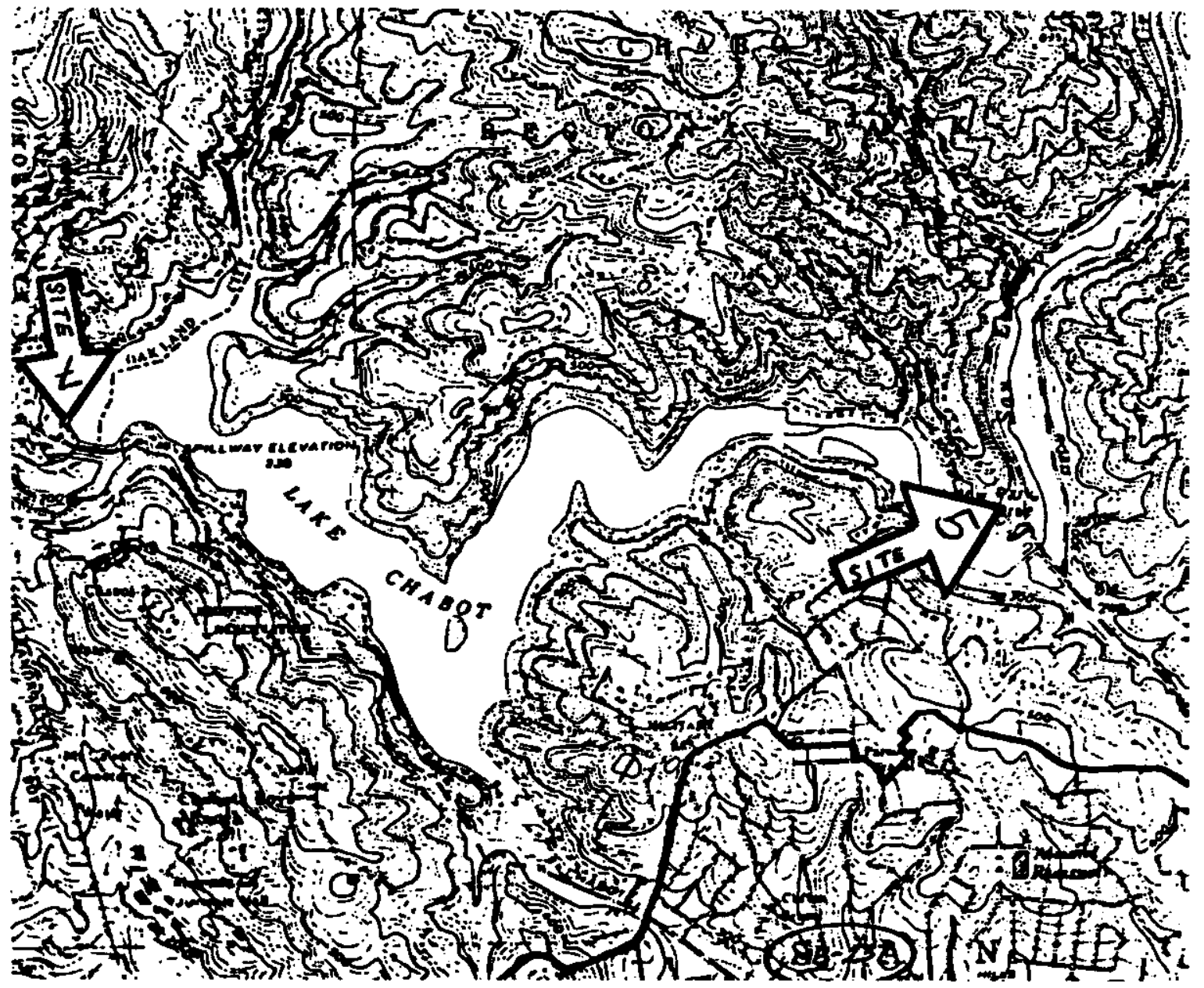

Figure 1. Locations of Sites 5 and 7 on map (Scale 1" $=2000^{\prime}$ )

\section{Description of Site 7 and Camera Settings for Infrared Photography:}

This site is located in San Leandro by a public park. The area photographed was in partial sun. There was a big garbage can in the middle of the stream. In the water, there was a lot of moss and many insects. Along the stream, there was not much vegetation - no shrubs - because of the wide use of it by the public. The vegetation that was found was: Willow, Bay, Poplar, and Eucalyptus. The water on the bottom of the stream was stationary, but the water on the top had a slight current. There was a little rock island where the photographs were taken. It was mostly a rocky area with some dead shrubs. This site is near a residential area. The water depth was much less than 12 inches. Figure 1 shows the exact location of this site. Table 3 shows the camera settings for the infrared photographs taken at site 7 . 
Table 2. Camera settings for Site 5 photographs

\begin{tabular}{|c|c|c|c|}
\hline & \multicolumn{3}{|c|}{ Ofration } \\
\hline 1 & $8^{*}$ & $1 / 125$ & vegetation \& water \\
\hline 2 & 5.6 & $1 / 125$ & vegetation \& water \\
\hline 3 & 11 & $1 / 125$ & vegetation \& water \\
\hline 4 & $11^{\star}$ & $1 / 125$ & vegetation only \\
\hline 5 & 16 & $1 / 125$ & vegetation only \\
\hline 6 & 8 & $1 / 125$ & vegetation only \\
\hline 7 & $5.6^{\star}$ & $1 / 125$ & water only \\
\hline 8 & 4 & $1 / 125$ & water only \\
\hline 9 & 8 & $1 / 125$ & water only \\
\hline 10 & 11 & $1 / 125$ & water only \\
\hline
\end{tabular}

"Exposure for 100 ASA from the camera exposure meter.

\section{Description of the "East 14th" Site:}

This site is located off East 14th Street in San Leandro in the middle of the busy city. The water depth was about 8 inches. This area was somewhat (moderately) fithy. There was vegetation all around the site. It was surrounded by Poison Ivy, Oxalis, Curbiticiae, Eucalyptus, Berry Rubra, Box Elder, Willow, and Vinca. There was a large amount of dead shrubs and the water was filthy. This site is located off a major street. The location of this site is given in Figure 2. Table 4 shows the camera settings for the infrared photographs taken at the East 14th site.

Table 3. Camera settings for Site 7 photographs

\begin{tabular}{|c|c|c|c|}
\hline $\begin{array}{c}\text { Theforiath } \\
\text { Nember }\end{array}$ & 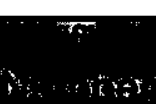 & $\begin{array}{l}\text { Shwter } \\
\text { Solajo: }\end{array}$ & Obsenhtions \\
\hline 11 & $8^{\star}$ & $1 / 125$ & vegetation \& water \\
\hline 12 & $8-5.6$ & $1 / 125$ & vegetation \& water \\
\hline 13 & $8-11$ & $1 / 125$ & vegetation \& water \\
\hline 14 & $5.6^{*}$ & $1 / 125$ & water only \\
\hline 15 & 4 & $1 / 125$ & water only \\
\hline 16 & 8 & $1 / 125$ & water only \\
\hline 17 & $5.6-8^{\star}$ & $1 / 125$ & vegetation only \\
\hline
\end{tabular}

*Exposure for $100 \mathrm{ASA}$ from the camera exposure meter. 


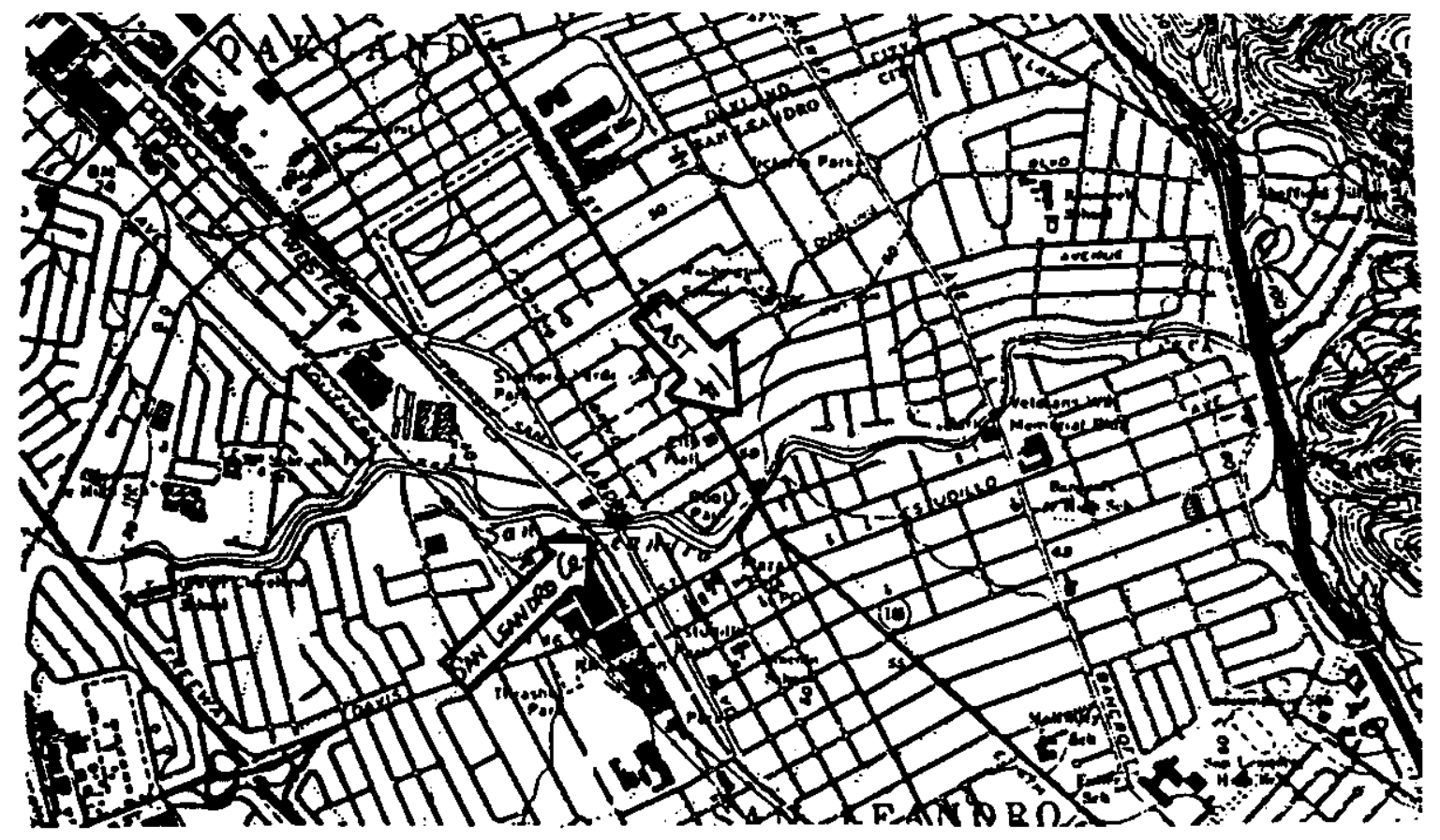

Figure 2. Locations of the East 14th Street and San Leandro sites on map (Scale 1" = 2000')

Table 4. Camera settings for "East 14th" site photographs

\begin{tabular}{|c|c|c|c|}
\hline PFopolaph & Number & Shutter & Hobservations \\
\hline 18 & $4^{\star}$ & $1 / 125$ & water only \\
\hline 19 & $4-5.6$ & $1 / 125$ & water only \\
\hline 20 & 5.6 & $1 / 125$ & water only \\
\hline$\overline{22}$ & $4^{\star}$ & $1 / 60$ & water only \\
\hline 22 & 4 & $1 / 125$ & vegetation \& water only \\
\hline 23 & 4 & $1 / 60$ & vegetation \& water only \\
\hline 24 & 4 & $1 / 60$ & vegetation \& water only \\
\hline 25 & $\overline{5.6}$ & $1 / 60$ & vegetation \& water only \\
\hline 26 & 4 & $1 / 160$ & vegetation only \\
\hline 27 & 5.6 & $1 / 160$ & vegetation only \\
\hline
\end{tabular}

\section{Description of "San Leandro" Site and Camera Settings for Infrared Photography}

This area is located in the center of the urban city of San Leandro. This site was extremely filthy. There were things like clothes and old road signs in the stream. It is by a major street and there are businesses around it. The area photographed is by a bridge. The first six pictures were taken at water level under the bridge. The last three photographs were taken from the top of the bridge. There was a decent amount of vegetation around the area. Among these were: Willow, Elder Berry, Acacia, Baccharius and Eucalyptus. There were many new and unknown plants. The water was polluted heavily. The 
water depth was less than 12 inches. This site location is shown in Figure 2. Table 5 shows the camera settings for the infrared photographs taken at the San Leandro site.

\section{Hypothesis}

I hypothesize that infrared photographs will show very little pollution at the first two sites (sites 5 and sites 7) and that the other two sites may exhibit a significant difference possibly indicating the effects of contamination of the water stream.

Table 5. Camera settings for "San Leandro" site photographs

\begin{tabular}{|c|c|c|c|}
\hline 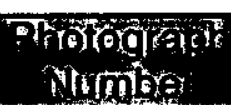 & Nurbor & 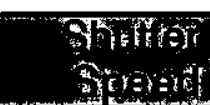 & Thsen,floms \\
\hline 28 & $8^{\star}$ & $1 / 125$ & vegetation \& water \\
\hline 29 & 5.6 & $1 / 125$ & vegetation \& water \\
\hline 230 & 11 & $1 / 125$ & vegetation \& water \\
\hline 31 & $5.6^{\star}$ & $1 / 125$ & water only \\
\hline 32 & 4 & $1 / 125$ & water only \\
\hline 33 & 8 & $1 / 125$ & water only \\
\hline 34 & $8^{\star}$ & $1 / 125$ & vegetation only \\
\hline 35 & 5.6 & $1 / 125$ & vegetation only \\
\hline 36 & 8 & $1 / 125$ & vegetation only \\
\hline
\end{tabular}

"Exposure for 100 ASA from the camera exposure meter.

\section{Results}

In view of the fact that I was taking infrared photographs for the first time and the extreme care the film required (keeping it in the freezer before use and transporting it in ice pack for processing, etc.), the overall results appear to be quite successful. I learned that part of my hypothesis was true. Through the photographs (vegetation damage) I could deduce that the San Leandro site was by far the most polluted site. From the color of the photographs, it seemed that the even thought I had predicted that the East 14th street site to be dirty also, it did not exhibit the pollution effects. Site 7 was also quite clean even though some of the vegetation around the water was diseased, but the water appeared to be clear. Site 5 , as hypothesized had remained the least polluted site of the four.

I expected that there would be two major effects of water pollution on infrared film. First, the water color change would indicate contamination. Second, the surrounding vegetation color would change due to water pollution. I think both effects were visible in this research. Detecting water color was more difficult to see because of several reasons that are discussed below (water depth, temperature, etc.). Foliage damage was more easily detectable through the pictures.

An interesting thing that I discovered when I was looking at the photographs was that the black color in the photograph may not always mean that the water is clear (as stated in Table 1). When one sees aerial infrared pictures of lakes, 
rivers, etc., they appear black. In the pictures that I took, the water color was sometimes black and sometimes transparent. Since my picture was mostly close-up shots, perhaps the water color turns dark only for long-distance shots. However, the color discrepancy could aiso have been due to the temperature of the water since infrared film basically measures temperature. It is possible that because the water was warm, there was a variation in the color. In photograph 2 , one can see that there are several dark spots, yet there are also other spots which are extremely light. In the areas where there is less light due to big trees, the water color seems to remain black because the temperature of this water must be cooler than the temperature of the water where there are no trees. The areas where the water temperature is warmer due to the exposure to broad sunlight, the color tends to become a bluish green. It is also possible that deep water may seem to be black while shallow water seems to be bluish-even though it is clear.

Other uncertainties in the conclusions may be due to film exposure. We had to bracket our exposures because the exact film speed was not given. When I got back all 36 of my pictures, I learned that different film exposures may change the degree of the color in the photograph. For example, in photographs 2 and 3 , which are of the same location, one sees that because the exposure is different, the color of the water changes from black to blue.

Site 5: Photograph 1, which is for site 5, shows mostly water and a little bit of vegetation on the sides. This photograph is really dark because the area in which it was taken was deep into the forest where sunlight was scarce. Even though it was a bright and sunny day, there was not too much light there. Also, according to table 1 , the black color of the water in the color infrared photograph is a sign of clear water. This fits in with my hypothesis because I predicted that this site would be the least polluted site from among the four photographed. But this does not mean that site 5 is extremely pristine because photograph 1 also displayed a lot of greenish, bluish tones around the water which stands for diseased or deficient vegetation. So even though the water was clear the photograph showed quite a bit diseased vegetation around the water. It seems odd that the vegetation appears to be diseased in an area where the water appeared to be very pristine and clear. This could be because the water is not deep enough, the photograph was under or over exposed, or because the plants really are diseased.

Site 7: Photograph 2 and photograph 3 are taken at site 7. These two pictures are the same except that the exposure is different. The exposure in Photograph 2 is greater than that in Photograph 3. There is a big difference in the two pictures as seen by the different colors. Both pictures were taken at the same time, same place, and with the same camera with the exception of film exposure. It is obvious that choosing the right exposure is extremely important because it changes the colors in infrared photography, which can completely change the results and conclusions. The black water in photograph 3 means that the water is clear, while the bluish water in photograph 2 could mean that the water is muddy and silted. Which photograph is more accurate? How can we tell? These questions are very hard to answer because when one is taking 
the pictures, one may not be aware of these factors - which was true in my case. These results, however, show the need for detailed note taking while doing the research and repeating the photographs on another day under different weather conditions.

East 14th Site: Photograph 4 was taken at the East 14th site. The overall quality of environment seems to be quite good even though I hypothesized that this site would be more on the polluted side. The bright red colors of the vegetation indicate that everything is quite healthy. The blue diseased portion seemed to be the area where there is a trail that is commonly used by people. The water color seemed to vary from dark to light. I think that a lot of the color change was a result of the shadows that came from the trees that were high above. This site was surrounded by bushy, tall trees where sunlight came through the trees. Perhaps certain areas that were exposed by the sun became a lighter color because the water there was warmer. The colder water could have come out to be black because of the cold temperature. The water depth could have also been a problem in using the color of the photographs to assess pollution.

San Leandro Site: Photographs 5 and 6 were taken of this site. The most successful pictures were from this site. This seemed to be the most polluted site of the four. The effect of this site being located in a rural area was easily shown by all the blue-green color that is shown by the water. It is easily seen that in photograph 6 a lot of the surrounding vegetation is blue and not red. This could show pollution because this site is located by a major street where there are a lot of industrial shops, businesses, and restaurants. In photograph 5 one can see that the blue vegetation continues along the creek and if one looks closely, the blue continues slowly up the tree into the branches and the leaves. This could possibly mean that there is something in the water that is causing the vegetation to become diseased all the way to the top of the trees. Perhaps it is all the garbage that is thrown into the creek by the street or the nearby businesses.

\section{Conclusions and recommendations}

One can conclude from the above discussions that the method of using color infrared photography in evaluating water quality appears to be promising. It was difficult to see the effect of pollution directly on the color of the water stream, but was easily visible in the vegetation and plant life near the water. Although the transition from a slide to the color prints in Photographs 1 through 6 resulted in a loss of the picture quality, the photograph is still readable.

This research was delayed due to bad weather conditions for infrared photography that required sunny weather. Also once the photographs were taken, it was found that the film processing took 6 weeks that further added to the delay in completion of the project. 
I would like to give the following specific recommendations at the conclusion of my project:

1. Due to the promising nature of the method of using infrared photography to evaluate water quality, this work should be continued.

2. Repeatability of results is very important due to the uncertainties in infrared color photography. The same site should be photographed again and results compared.

3. Chemical analysis of the water and vegetation in the photographed area should be performed and the results judged against real pollution effects.

4. In a separate indoor/outdoor infrared color photography project, the data in table 1 should be reproduced. Care should be taken in bracketing the film exposures.

5. The effect of film exposure bracketing should also be investigated.

6. The project should also be performed in winter when water temperatures are much lower. Different conclusions may result.

\section{Acknowledgments}

I would like to sincerely thank Mr. John Petersen of Castro Valley High School and Dr. Asif Arastu for all their support during the research whose results are reported in this paper.

I would also like to acknowledge the Lawrence Livermore National Laboratory who supported this research.

\section{References}

1. Glanfield, Colin, Techniques of Filters and Special Effect Photography, New Jersey: Chartwell Books Inc., 1982.

2. Mates, Robert E., Photographing Art, New York: American Photographic Book Publishing Co., Inc., 1966.

3. Simon, Ivan, Infrared Radiation, D. Van Nostrand, 1966.

4. Tresidder, Jack, Creating Special Effects, Kodak Limited, Mitchell Beazley Publishers, Salvat Editores, S.A. 1984.

5. Applied Infrared Photography. Eastman Kodak, 1968.

6. "How to Shoot Infrared," Popular Photography, September 1993, p. 54.

7. "Infrared Photography," Encyclopedia of Practical Photography, 1978. Vol. 8, pp. 1409-1430.

8. Infrared and Ultraviolet Photography. Eastman Kodak, 1963.

9. "Professional Photographic Illustration Technique," Photography as a Tool. Eastman Kodak Company, 1978.

10. "Kodak Infrared Films," New York, Eastman Kodak Company, 1976, p.4. 


\section{Biochemical Analysis of Aquatic Insects}

Kao Vang, Julie Hui, Yia Vang, Johanna Mangahas, and Monica DeAnda

Teacher: Mrs. Margaret Johnson

\section{Edison High School}

Stockton, CA

\section{Introduction}

Few studies have been done on the genus Rhyacophila (a caddisfly) of the Order Trichoptera. This includes taxonomic keys, both morphological and biochemical methods, to differentiate various Rhyacophila larvae to their proper species. Two physically dissimilar larvae have been collected from Mills Creek in the Foothills of California, which have been keyed to the same Rhyacophila genus. However, without sufficient taxonomic keys, we were unable to finalize whether the two specimens belong to the same species.

One of the insects (Fig.1) has tufts of bushy lateral gills all along the abdomen, but no gills on the thorax, unlike the Himalopsyche (Fig. 3), a genus of the same family Rhyacophilidae.. The other insect (Fig. 2) has a single hair projecting from each side of each abdominal segment, like the Rhyacophila in Fig. 4.

We received two letters from two of the current North American experts in the area of caddisfly research, Dr. Glenn B. Wiggins, Curator Emeritus of the Department of Entomology of Royal Ontario Museum, and Dr. Stamford D. Smith, Chair of the Department of Biology of Central Washington University. Both state that the two larvae are different species. Dr. Smith suggests that the "Iarva with the bushy gills is most likely a member of the Rhyacophila brunnea group (it used to be called acropedes)". However, he doesn't know the other larva, indicating it might be a new species.

Since the assumption is that the two larvae are different species, the purpose of this research is to determine if we can biochemically confirm that two morphologically distinct Rhyacophila larvae are indeed different species. Before this question can be answered, a series of other questions and problems must be solved. One of these problems is to develop a protocol to isolate the insects' DNA. The rest will be determined by more research and tests (which will be be discussed later in the Discussion Section).

\section{Materials and Methods}

\section{Part 1: DNA Isolation}

\section{Prelab Preparation}

1) The SDS/sodium hydroxide solution must be fresh; prepared within a few days prior to lab.

2) Aliquot for each experiment: 
$160 \mu$ of Tris/EDTA (TE) solution for each tube.

$200 \mu \mathrm{l}$ of SDS/sodium hydroxide (SDS/ $\mathrm{NaOH}$ ) solution for each

tube

ice) for

$150 \mu$ of potassium acetate/acetic acid (KOAc) solution (store on each tube

$400 \mu l$ of isopropanol for each tube

$100 \mu \mathrm{l}$ of $95 \%$ ethanol for each tube

3) Obtain five insects of the same species (stoneflys).

\section{Materials}

CULTURE AND REAGENTS

insects (stoneflys)

Tris/EDTA (TE)

SDS/sodium hydroxide (SDS/NaOH) potassium acetate/acetic acid (KOAC) isopropanol

$95 \%$ ethanol

distilled water

\section{SUPPLIES AND EQUIPMENT}

100-1000 $\mu \mathrm{l}$ micropipet and tips

10-100 $\mu \mathrm{l}$ micropipet and tips

0.5-10 $\mu \mathrm{l}$ micropipet and tips $1.5 \mathrm{ml}$ eppendorf tubes

beaker of crushed ice beaker for waste/used tips clean paper towels

microfuge

permanent marker

test tube rack

mortar and pestle

graduated cylinder

fine sand

sterile gauze pads

funnel

\section{Procedure}

1) Heat a small amount of fine sand grains to $150^{\circ} \mathrm{C}$ for half an hour (to sterilize the sand). The sand acts as a protective layer between the pestle and the cellular materials embedded underneath and between the sand grains.

2) Place sterile sand and 5 insects into mortar. Add $3 \mathrm{ml}$ water.

3) Grind contents until bugs are completely smashed.

4) Filter content into test tubes through sterile gauze pad. Keep filtrate and discard rest of contents. (solids)

5) Centrifuge test for 5 minutes (to concentrate nuclei content). Pour solution in drain and keep pellet.

6) Dry pellet by turning tube upside-down on top of paper towel. 
7) Add $100 \mu$ ice-cold TE buffer to pellet in each tube. Mix content with micropipet by stirring the pipet around the solution, then pump up and down. Keep tip off the bottom and stir again.

8) Add $200 \mu \mathrm{l}$ SDS/ $\mathrm{NaOH}$ in each tube. (SDS lyses cells and nucleic membranes to elease the DNA. $\mathrm{NaOH}$ will dissolve any organic materials in solution.)

9) Add $150 \mu$ ice-cold KOAc into each tube. Mix content by inverting tube. (KOAc will precipitate protein.)

10) Centrifuge tubes for 5 minutes. Pipet liquid and discard it. Keep pellet in test tube. (In pellet are heavy weight DNA (chromosomal DNA) entrapped in SDS/lipid/protein content.)

11) Add $30 \mu$ I TE to pellet. Mix content gently by carefully rocking tube back and forth.

12) Centrifuge tube for 5 minutes. Pipet solutions from all tubes into one tube and discard pellet. (In solution are DNA/lipid/SDS. Pellet is precipitated proteins.)

13) Add $400 \mu$ lisopropanol to solution to precipitate DNA.

14) Centrifuge tube for 5 minutes. Pipet solution and discard it. DNA pellet is left in the tube.

15) Add $100 \mu / 95 \%$ ethanol to wash and fully precipitate DNA.

16) Dry DNA pellet by centrifuging tube for 2 minutes and carefully draw off ethanol using a 10-100 $\mu \mathrm{l}$ micropipet. Allow pellet to air dry at room temperature for 10 minutes until you cannol smell the alcohol before proceeding to the next step.

17) Add $30 \mu$ of TE and resuspend pellet by pipetting in and out.

18) Freeze DNATTE solution at $-20^{\circ} \mathrm{C}$ until ready to continue. Thaw before using.

19) Take time for responsible cleanup.

\section{Part II: Restriction Analysis of Isolated DNA}

\section{Prelab Preparation}

1) Prepare $0.8 \%$ agarose solution (approximately $40-50 \mathrm{ml}$ per gel being made). Keep agarose liquid on a hot plate (at about $60^{\circ} \mathrm{C}$ ) throughout the experiment. Cover solution with aluminum foil to retard evaporation.

2) Prepare 1X TBE buffer for electrophoresis $(400-500 \mathrm{ml}$ per experiment). 
3) Prepare ethidium bromide (100 $\mathrm{ml}$ per experiment).

4) Adjust water bath to $37^{\circ} \mathrm{C}$.

\section{Materials}

REAGENTS

Isolated DNATE

EcoR1 restriction enzyme

Loading dye

$0.8 \%$ agarose

$1 \times$ TBE buffer

$1 \mu \mathrm{g} / \mathrm{ml}$ ethidium bromide
SUPPLIES AND EQUIPMENT

0.5-100 $\mu \mathrm{l}$ micropipet and tips

$1.5 \mathrm{ml}$ eppendorf tubes

Aluminum foil

Beaker for agarose

Beaker for waste/used tips

Electrophoresis box

Masking tape

Microfuge

Camera and film

Permanent marker

Power supply

Rubber gloves

Test tube rack

Transilluminator

$37^{\circ} \mathrm{C}$ water bath

\section{Procedure}

I. Set Up Restriction Digest

1) Mark the number of tubes you want to run in the gel.

2) Add $10 \mu l$ of the DNATE to each tube.

3) Use fresh tips to add $1 \mu$ l EcoR1 to each tube.

4) Close tube tops. Pool and mix reagents by pulsing in a microfuge or by sharply tapping the tube bottom on lab bench.

5) Place reaction tube in $37^{\circ} \mathrm{C}$ water bath. Incubate for 1 to 3 hours

*STOP POINT Following incubation, freeze reactions at $-20^{\circ} \mathrm{C}$ until ready to continue. Thaw reactions before continuing to Section III, Step 1.

II. Cast $0.8 \%$ Agarose Gel

1) Seal ends of gel-casting tray with tape. Insert well-forming comb. Place gel-casting tray out of the way on lab bench so that agarose poured can set.

2) Carefully pour enough agarose solution into casting tray to fill to a depth of about $5 \mathrm{~mm}$. 
3) Do not move tray while agarose is solidifying (about 30 minutes).

4) When agarose has set, unseal ends of casting tray. Place tray on platform of gel box, so that comb is at negative (black) electrode.

5) Fill box with TBE buffer to a level that just covers entire surface of gel.

6) Gently remove comb, taking care not to rip wells.

7) Make certain all wells are filled with buffer. continue.

*STOP POINT Cover electrophoresis tank and save gel until ready to

\section{Load Gel and Electrophorese}

1) Add $2 \mu$ loading dye to each reaction tubes. Close tube tops and mix by tapping tube bottom on lab bench, pipetting in and out, or pulsing in a microfuge.

2) Use micropipettor to load entire contents of each reaction tubes into separate well in gel. Use fresh tip for each reaction.

3) Close top of electrophoresis box. Connect electrical leads to a power supply. Make sure both electrodes are connected to the same channel of power supply.

4) Turn power supply on. Set voltage to $100 \mathrm{~V}$.

5) Electrophoreses for about 2 hours. Stop electrophoresis before bromophenol blue band runs off the end of the gel.

6) Turn off power supply. Disconnect leads from inputs. Remove the top of the electrophoresis box.

7) Carefully remove casting tray from electrophoresis box. Slide gel into disposable weigh boat or other shallow tray. Label staining tray.

8) Stain and view gel as described below.

IV. Stain Gel with Ethidium Bromide and View

1) Flood gel with ethidium bromide solution $(1 \mu \mathrm{g} / \mathrm{mm})$. Allow to stain for 10-15 minutes.

2) Following staining, use funnel to decant as much ethidium bromide solution as possible from staining tray back into storage container. 
3) View under ultraviolet transilluminator or other UV source.

4) Take time for responsible cleanup.

\section{Photograph Gel}

\section{Results}

Figures $5 \& 6$ are photographs of our first trial; Fig. 7 from the second trial; Fig. 8 $\& 9$ from the third, and Fig. 10 from the fourth trial.

Figure 5 is a photograph of the gel containing the DNATE solution obtained at the end of the DNA isolation procedure. There is no indication of any DNA in the gel due to the lack of stain or bands.

Figure 6 is a photograph of the gel loaded with the supernatant drained from step 5 of the DNA isolation procedure. Samples of the supernatant restricted with EcoR1 restriction enzyme were loaded in wells 2, 4, 6, and 8.

The second trial yielded the same results as in the first trial. No stains or bands are present in the tubes that are supposed to contain DNA in the DNA/TE solution (picture not shown). Samples of the supernatant drained from step 5 were restricted with EcoR1 and loaded in wells 1, 2, 3, and 4. Like the prior trial, stains were present in each of the loaded wells. (Fig. 7)

The third trial, where sand was not used during the grinding process, showed no DNA (picture not shown). The samples of supernatant drain from step 5 shows evidence of DNA; however, this is the only trial that the DNA ever migrated from the well. (Fig. 8 \& 9)

The fourth trial also did not use sand for grinding. Strangely, no DNA was evdent in either the DNAVTE solution or in the supernatant drained from step 5. (Fig. 10)

We have performed a few more trials and their results are similar to either Trials 1,2 , or 4 (pictures not shown).

\section{Discussion}

We have only a handful of the Rhyacophila larvae, so we used another type of aquatic insects, stoneflys, in our attempt to develop and test a protocol which will be successful in isolating the insects' DNA. When Fig. 5 shows no evidence of DNA, we assume we have lost the DNA in one of the prior steps. Trying to locate where the DNA is, or to see if any at all was extracted from the insects, all of the discarded materials were saved and electrophoresed. An example is Fig. 6 in which the discarded material is the supernatant. Since Fig. 6 shows evidence of DNA, we know we definitely extracted DNA with our crude methods. As an explanation for why we did not obtain DNA in the final step of the extraction procedure, we assume errors were made in our work. We are still in the process of identifying what those errors were. 
A careful trial was performed again and the results were the same as our initial trial. This indicates our working technique is not the problem. In an attempt to find another reason why our procedure is not working, we tried another trial without using sand when grinding the insect (Trial 3). Electrophoresis indicates no DNA present in the DNATTE solution. There was no DNA migration from the wells in Fig. 6 \& 7 because undissolved material and high-molecular weight DNA are too big and are trapped at the front edge of the well.

Performing another trial (Trial 4) without using sand to verify Trial 3 , electrophoresis of both the supernatant and DNA/TE solution showed no evidence of DNA. From our data we conclude that our present protocol is inadequate in isolating DNA. Thus we cannot yet confirm biochemically that the two morphologically distinct Rhyacophila larvae are separate species. What we do know is that we need to modify or find another protocol which will isolate DNA.

One hypothesis as to why DNA is in the supernatant and not in the DNATE solution is that the DNA was never pulled down into the pellet during the centrifuge in the beginning of step 5. The DNA may be too small and our centrifuge is not spinning fast enough to pull the DNA down. Due to lack of time, we have not tested this hypothesis. But if it is right, the supernatant can be ultracentrifuged at an extremely high RPM and for a longer duration than 5 minutes; then the DNA might be pulled into a pellet. This pellet should then be carried through with the rest of the procedure rather than the original pellet, which should contain any insect parts, sand, or other materials that went through the filter.

Some key points to remember for future research and tests are:

- Our tests were done without emphasis on sterility. The trials were merely to determine if the DNA could be isolated. Therefore, contamination may be a problem.

- Once DNA is extracted, what would be the best restriction enzyme to use to cut the DNA?

- Be aware of physics behind centrifuging; i.e., the relationship between speed of the spin, duration of the spin, and what mass it can pull down.

- What else does ethidium bromide stain?

- Even if we could biochemically analyze insects, how would we know the difference in the amount of variation between individuals within the same or different species?

- If we need to know how much of a difference there is between the banding sequence within the same species, we would have to scale down the protocol to using one insect.

- Determine a way to empty the stomach of the insect as the DNA of the insect food will be amplified during PCR as well as the insect DNA.

- What primer should we use for the PCR? 


\section{Acknowledgments}

We want to thank the following people for their help and contribution with our project:

Margaret Johnson, Biotechnology Instructor, Thomas Edison High School

Eugene J. Bisagno, Jr., Biology Instructor, Thomas Edison High School

Richard Filson, Biology Instructor, Thomas Edison High School

Dr. Glenn B. Wiggins, Curator Emeritus, Department of Entomology of Royal Ontario Museum

Dr. Stamford D. Smith, Chair Department of Biology of Central Washington University

Dr. Carol L. Boggs, Director of the Center for Conservation Biology, Stanford University

Dr. Craig Vierra, Biology Instructor, University of the Pacific (UOP)

\section{References}

1) Micklos, David A. \& Freyer, Greg A. (1990) DNA Science. Carolina Biological Supply Co., North Carolina.

2) Wiggins, Glenn B. (1977) Larvae of the North American Caddisfly Genera (Trichoptera). University of Toronto Press, Toronto. 
The Effect of Different Concentrations of Miracid on the Growth of Stringless Bush Beans

Hanh M. Vo, Kelly J. Tan, Linda Yang, Hoa Pham,

Sopheunn Cheng, and Esmeralda Zendejas

Teacher: Margaret Johnson

Edison High School

Stockton, CA

\section{Introduction}

The purpose of this research was to find out the effects of different concentrations of miracid on the growth of stringless bush beans. Miracid is used to help plants receive their nutrients to grow. For this research project we have designed an experiment to show how much miracid affects the growth of stringless bush beans.

\section{Materials and Methods \\ 8 plastic cups \\ Miracid \\ $100 \mathrm{ml}$ graduated cylinder \\ Balance \\ Seeds \\ Water \\ $\mathrm{pH}$ paper \\ Plastic bags \\ Paper towels}

Take eight cups and place $50 \mathrm{ml}$ of water in each cup. Then make the seven different concentrations of miracid which are: $0.1 \mathrm{~g}, 0.2 \mathrm{~g}, 0.3 \mathrm{~g}, 0.4 \mathrm{~g}, 0.5 \mathrm{~g}, 1.0$ $\mathrm{g}$, and $2.0 \mathrm{~g}$. Place one different concentration in each of the seven cups; make sure one cup has no miracid as this is the control. Then take the $\mathrm{pH}$ measurement of each of the liquid solutions. Place 5 seeds in each of the eight cups for about 6 hours. Then dry the five seeds from the different concentrations and wrap each group of 5 seeds in a piece of moist paper towel. Take the wrapped seeds from the different concentrations and place them in eight separate plastic zip-lock bags. Observe their growth and record it each day. 


\section{Results}

Effect of Different Concentrations of Miracid on Growth of Bush Beans

\begin{tabular}{|c|c|c|c|c|c|c|c|c|}
\hline $\begin{array}{c}\text { DAY } \\
\text { S }\end{array}$ & $\begin{array}{c}\text { Contro } \\
\text { I }\end{array}$ & $0.1 \mathrm{~g}$ & $0.2 \mathrm{~g}$ & $0.3 \mathrm{~g}$ & $0.4 \mathrm{~g}$ & $0.5 \mathrm{~g}$ & $1.0 \mathrm{~g}$ & $2.0 \mathrm{~g}$ \\
\hline 1 & 3 & 4 & 1 & 2 & 1 & 2 & 1 & 1 \\
\hline 2 & 3 & 4 & 2 & 2 & 1 & 2 & 1 & 1 \\
\hline 3 & 3 & 4 & 2 & 2 & 1 & 2 & 1 & 1 \\
\hline 4 & 3 & 4 & 2 & 2 & 1 & 2 & 1 & 1 \\
\hline 5 & 3 & 4 & 2 & 2 & 1 & 2 & 1 & 1 \\
\hline 6 & 3 & 4 & 2 & 2 & 1 & 2 & 1 & 1 \\
\hline
\end{tabular}

\section{Sprouting Beans in Different Concentrations of Miracid}

\section{Number}

of Sprouts

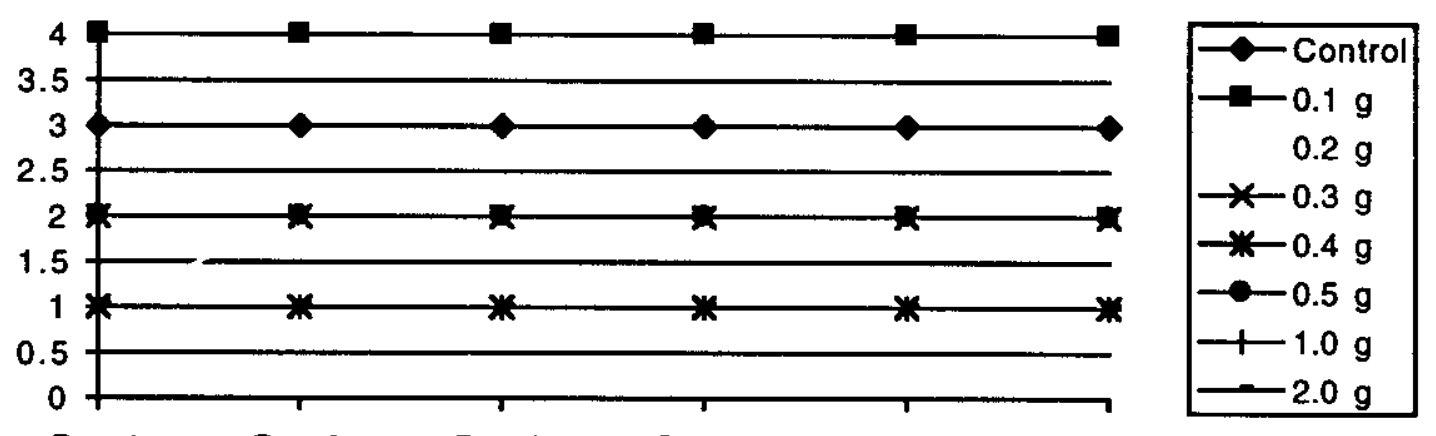
Day 1
Day 2
Day 3
Day 4
Day 5
Day 6

D A Y S

\section{Discussion}

Our results and observations show that the more concentrated the water is with miracid the lower the chance is for the bush beans to sprout. Therefore, we conclude that too much miracid may reduce the chances for the bush beans to sprout and grow. 
The Effect of Different Concentrations of Calcium Chloride on the Growth of Bush Beans

\author{
Vanna Chau \\ Teacher: Margaret Johnson \\ Edison High School \\ Stockton, CA
}

\title{
Materials and Methods \\ Graduated cylinder \\ Balance \\ Calcium Chloride \\ Scupula \\ 7 plastic cups \\ Beans \\ Water \\ Plastic bags \\ Paper towel
}

First, I massed the calcium chloride into different amounts. After massing, I got 7 regular plastic cups and measured out $120 \mathrm{ml}$ of water. Then I added the different amounts of calcium chloride to the $120 \mathrm{ml}$ of water in each cup. One of the cups didn't have any chemical. I labeled each cup with the different concentrations: $1.0 \mathrm{~g}, 2.0 \mathrm{~g}, 4.0 \mathrm{~g}, 6.0 \mathrm{~g}, 8.0 \mathrm{~g}$, and $10.0 \mathrm{~g}$. Then I got the Blue Lake bush beans and placed six of them in each of the plastic cups. I let the beans soak for 6 hours. Then I took them out and placed each cup of beans in different zip lock bags. For two weeks I took results of the growth of my beans. I watched to see if the concentration had any effect on the growth of the beans.

\section{Results}

\begin{tabular}{|l|l|l|l|l|l|l|l|}
\hline Days & $\begin{array}{l}\text { Contro } \\
1\end{array}$ & $1.0 \mathrm{~g}$ & $2.0 \mathrm{~g}$ & $4.0 \mathrm{~g}$ & $6.0 \mathrm{~g}$ & $8.0 \mathrm{~g}$ & $10.0 \mathrm{~g}$ \\
\hline 1 & 0 & 0 & 0 & 0 & 0 & 0 & 0 \\
\hline 2 & 0 & 0 & 0 & 0 & 0 & 0 & 0 \\
\hline 3 & 0 & 0 & 0 & 0 & 0 & 0 & 0 \\
\hline 4 & 1 & 1 & 1 & & & & \\
\hline 5 & 2 & 1 & 1 & 1 & & & \\
\hline 6 & 2 & 1 & 1 & 1 & & & \\
\hline 7 & 3 & 2 & 1 & 1 & & & \\
\hline 8 & 3 & 2 & 2 & 1 & & & \\
\hline 9 & 3 & 2 & 2 & 1 & & & \\
\hline 10 & 4 & 2 & 2 & 1 & & & \\
\hline 11 & 4 & 3 & 2 & 1 & & & \\
\hline 12 & 4 & 3 & 2 & 1 & 1 & & \\
\hline 13 & 4 & 3 & 2 & 1 & 1 & & \\
\hline 14 & 5 & 3 & 2 & 1 & 1 & & \\
\hline
\end{tabular}




\section{Discussion}

The result of this experiment as compared with my hypothesis is nearly the same. This significant result was true: the higher the concentration of calcium chloride, the more it affected the growth of the beans. The lesser the amounts of calcium chloride, the more beans that sprouted.

\section{Acknowledgment}

I want to especially thank my IPS teacher, Mrs. Johnson, for all the help and all the things I learned with many different experiments throughout the year. Also thanks to Dr. John Knezovich from Lawrence Livermore National Laboratory for coming to our school and helping us out with the experiment.

\section{Reference}

I read a book called "Modem Biology" published by Holt, Rinehart and Winston 


\title{
The Effect of Different Concentrations of Liquid Plant Food on Stringless Bush Beans
}

\author{
Mai Moua and Sarie Theang
}

Teacher: Margaret Johnson

\section{Edison High School Stockton, CA}

\section{Introduction}

In this world we have many chemicals and products that may effect tomorrow's world. Some chemicals and products have harmful effects and some have helpful effects. For this particular research, we used plant food to test its effects on beans. The purpose of this research was to find out how much plant food has a better effect on beans. We observed how much beans would sprout in a certain amount of plant food.

Some students tried a similar method by putting beans into a cup filled with water and then added certain amounts of plant food. Instead of soaking the beans in the water for 6 hours, they left the beans in the cup with water and plant food in it through the whole experiment. They observed the cup every day. However, there were problems that occurred. The beans started to absorb so much water that they became large and fat. They floated above the water. Some beans became wrinkled and skinny. The beans caused the water to be moldy and odorous. This process was not a success for sprouting beans.

\section{Materials and Methods}

100 Lilly Miller Bluelake Bush Beans

10 Pixie Party crystal 9 oz. plastic cups

"Schultz-Instant" Liquid Plant Food

$100 \mathrm{ml}$ graduated cylinder

Paper towels

10 Reynolds Fresh-Lock Sandwich bags

Marker pen

Evan Natural Spring Water

First, we take a marker pen and labeled each plastic cup with a different concentration: $0 \mathrm{ml}, 1 \mathrm{ml}, 2 \mathrm{ml}, 5 \mathrm{ml}, 7 \mathrm{ml}, 10 \mathrm{ml}, 15 \mathrm{ml}, 18 \mathrm{ml}, 20 \mathrm{ml}$ and $22 \mathrm{ml}$. We also labeled sandwich bags with the same concentrations. We carefully counted 10 sets of 10 bush beans (making sure all the beans were not cracked) and placed each set in the previously labeled plastic cups. We measured ten sets of $100 \mathrm{ml}$ of water and poured it into the ten plastic cups. The plant food was measured to equal the amount indicated on each cup. One cup did not contain any plant food; this was the control.

The beans were left in the cups with the varying concentrations for 6 hours, then moved to the sandwich bag with the same concentration. We wet 20 pieces of paper towels and placed two in each sandwich bags. The beans in the cup labeled $0 \mathrm{ml}$ were then placed between the 2 paper towels in the sandwich 
bags. The purpose of this was to keep the beans moist. This step was repeated until all the beans were placed in their appropriately labeled bags. All the sandwich bags were placed by a window for maximum sun exposure. We observed and recorded each day how many beans sprouted in each of the sandwich bags.

Results

\section{Sprouting Beans In Liquid Plant Food}

$\mathrm{ml}$ of Liquid Plant Food

\begin{tabular}{|l|r|r|r|r|r|r|r|r|r|r|}
\hline & $15 \mathrm{~m}$ & $1 \mathrm{~m}$ & $2 \mathrm{~m}$ & $5 \mathrm{~m}$ & $7 \mathrm{~m}$ & $0 \mathrm{~m}$ & $10 \mathrm{~m}$ & $18 \mathrm{~m}$ & $20 \mathrm{~m}$ & $22 \mathrm{~m}$ \\
\hline Day 1 & 0 & 0 & 0 & 0 & 0 & 0 & 0 & 0 & 0 & 0 \\
\hline Day 2 & 0 & 0 & 0 & 0 & 0 & 0 & 0 & 0 & 0 & 0 \\
\hline Day 3 & 0 & 0 & 0 & 0 & 0 & 0 & 0 & 0 & 0 & 0 \\
\hline Day 4 & 0 & 0 & 0 & 0 & 0 & 0 & 0 & 0 & 0 & 0 \\
\hline Day 5 & 3 & 1 & 1 & 1 & 1 & 1 & 1 & 0 & 0 & 0 \\
\hline Day 6 & 4 & 1 & 1 & 1 & 1 & 1 & 1 & 0 & 0 & 0 \\
\hline Day 7 & 4 & 1 & 1 & 1 & 1 & 1 & 1 & 0 & 0 & 0 \\
\hline Day 8 & 4 & 1 & 1 & 1 & 1 & 1 & 1 & 0 & 0 & 0 \\
\hline Day 9 & 4 & 1 & 1 & 1 & 1 & 1 & 1 & 0 & 0 & 0 \\
\hline $\begin{array}{l}\text { Day } \\
\text { 10 }\end{array}$ & 4 & 1 & 1 & 1 & 1 & 1 & 1 & 0 & 0 & 0 \\
\hline
\end{tabular}

\section{Discussion}

Eventually, this experiment had sprouted beans, unlike the experiment where they left the beans in the water. From this result we speculated that beans sprout better with a few drops of water which made them moist. By comparing these data, we learned that too much water may effect the sprouting of the beans.

From our observation, we found that just a certain amount of liquid plant food would help the beans sprout better. For instance, $1 \mathrm{ml}, 2 \mathrm{ml}, 5 \mathrm{ml}, 7 \mathrm{ml}$ and 10 $\mathrm{ml}$ liquid plant food had the same equivalent sprouting of beans as zero $\mathrm{ml}$ of liquid plant food. But $15 \mathrm{ml}$ of liquid plant food was different: it had a better effect on the beans by sprouting the most. On the other hand, $18 \mathrm{ml}, 20 \mathrm{ml}$ and $22 \mathrm{ml}$ had no results. None of the beans sprouted. Therefore, the significance of the findings of sprouting beans is that a certain amount of water and liquid plant food plays an important role in sprouting beans.

In conclusion, too much water may destroy the beans from sprouting. Also not enough plant food may just have the same result as the control which makes it sprout only one bean. As in that case we would need certain amounts of plant food to have good results in sprouting beans. 


\section{Acknowledgments}

We would like to thank Mrs. Johnson for giving us a once in a lifetime opportunity to participate in this project and for guiding us through it. Last, but not least, we would like to thank Dr. John Knezovich from Lawrence Livermore National Laboratory for helping us by giving advice and ideas for this experiment. 


\section{The Effect of Vegetable Oil on Bean Growth}

Sokphorn But, Huon Oeurn, and Srey Prum

Teacher: Margaret Johnson

\section{Edison High School Stockton, CA}

\section{Introduction}

The purpose of this research was to find if oil has an effect on the growth of the bean and the amount of oil it would take to cause that effect.

\section{Materials and Methods}

In our experiment we used 11 clear plastic cups. We placed the same amount of water in each cup. With the exception of one cup (the control), we placed oil in the cups. In all the cups 5 beans were soaked for 6 hours. From the cups the beans were placed in plastic bags and left by a sunny window. Each day the beans were studied for growth.

\section{Results}

\begin{tabular}{|c|c|c|c|c|c|c|c|c|c|}
\hline$\overline{D A Y}$ & Control & $2 \mathrm{ml}$ & $4 \mathrm{ml}$ & $6 \mathrm{ml}$ & $8 \mathrm{ml}$ & $10 \mathrm{ml}$ & $12 \mathrm{ml}$ & $14 \mathrm{ml}$ & $16 \mathrm{ml}$ \\
\hline 1 & 0 & 0 & 0 & 0 & 0 & 0 & 0 & 0 & 0 \\
\hline 2 & 0.4 & 0 & 0 & 0 & 0 & 0 & 0 & 0 & 0 \\
\hline 3 & 1.5 & 0.5 & 0.6 & $\overline{0}$ & 0 & 0 & 0 & 0 & 0 \\
\hline 4 & 1.6 & 0.6 & 0.6 & 0 & 0 & $\overline{0}$ & 0 & 0 & 0 \\
\hline 5 & 1.7 & 0.7 & 0.6 & 0 & 0 & 0 & 0 & 0 & 0 \\
\hline 6 & 1.8 & 0.7 & 0.7 & 0 & 0 & $\overline{0}$ & 0 & 0 & 0 \\
\hline 7 & 1.9 & 0.8 & 0.8 & 0 & 0 & 0 & 0 & 0 & 0 \\
\hline
\end{tabular}

\section{GROWTH}

(cm)

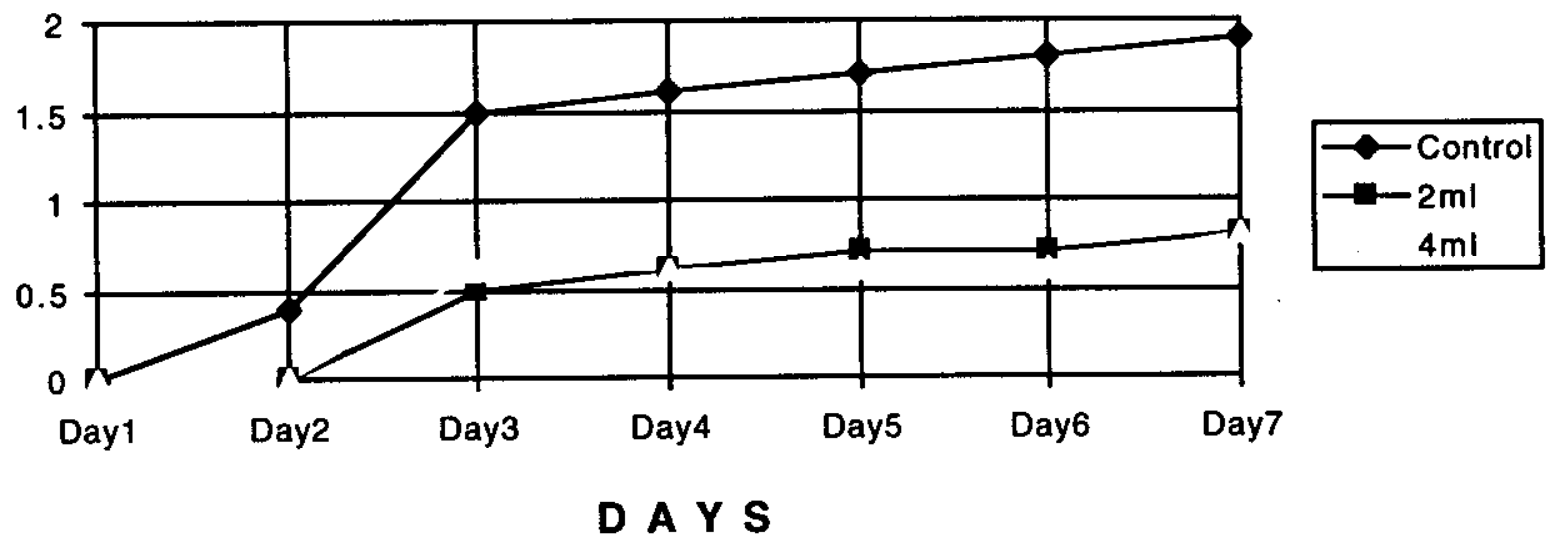




\section{Discussion}

The results indicate that the oil does have an effect on the growth of the beans. In fact, the beans do not grow as well as the control in all concentrations of vegetable oil. Even though the oil does not mix well with the water, the oil does seem to inhibit the growth of the beans.

\section{Acknowledgments}

We would like to thank Dr. John Knezovich of LLNL for his discussion at our class. This discussion helped to direct our research. We would also like to thank Mrs. Margaret Johnson, Science teacher at Edison High School, for supplying us with all our materials.

\section{References}

Biology: A Systems Approach, Addison-Wesley, 1988 


\section{The Effect of River Water on Lima Beans}

\section{Carolina T. Galvan, Francesca M. Bardo, and Valerie Cuson}

Teacher: Mrs. Margaret Johnson

\section{Edison High School}

Stockton, CA

\section{Introduction}

The purpose of this research was to find out if Stockton's Delta River water would have any effect on lima bean plants when mixed with tap water and when standing alone. We also wanted to find out if tap water had any effect on lima bean plants when mixed with Delta water and when it stands alone.

The reason we thought this experiment was important was because we wanted to know if Delta water (dirty water) would have any effect because of its uncleaness. Furthermore, we thought that if the water affects beans, its content might have an effect on Homo Sapiens.

\section{Materials and Methods}

We used lima beans, Delta and tap water, plastic cups and a graduated cylinder. At 8:00 PM we conducted our experiment.

The procedure we used goes as follows:

1. Lay out plastic cups

2. Measure $100 \mathrm{~cm}^{3}$ of tap water

3. Measure $100 \mathrm{~cm}^{3}$ of Delta water (use as control)

4. Fill a cup with $90 \mathrm{~cm}^{3}$ of tap water

5. Using the same cup, add $10 \mathrm{~cm}^{3}$ of river water

6. Label cup

7. Add 4 lima beans

8. Record growth day by day

9. Repeat $1-8$ for each cup using measurements of:

$80 \mathrm{~cm}^{3}$ of tap water $/ 20 \mathrm{~cm}^{3}$ of Delta water $70 \mathrm{~cm}^{3}$ of tap water $/ 30 \mathrm{~cm}^{3}$ of Delta water $60 \mathrm{~cm}^{3}$ of tap water $/ 40 \mathrm{~cm}^{3}$ of Delta water $50 \mathrm{~cm}^{3}$ of tap water $/ 50 \mathrm{~cm}^{3}$ of Delta water $40 \mathrm{~cm}^{3}$ of tap water $/ 60 \mathrm{~cm}^{3}$ of Delta water $30 \mathrm{~cm}^{3}$ of tap water $/ 70 \mathrm{~cm}^{3}$ of Delta water $20 \mathrm{~cm}^{3}$ of tap water $/ 80 \mathrm{~cm}^{3}$ of Delta water $10 \mathrm{~cm}^{3}$ of tap water $/ 90 \mathrm{~cm}^{3}$ of Delta water 
Results

We recorded each day of the experiment as it was in growth. We checked the growth every morning and evening. We used a data table:

\begin{tabular}{|c|c|c|c|c|c|c|c|c|c|c|c|c|}
\hline \multirow{2}{*}{\begin{tabular}{|l|} 
\\
Contro \\
I Tap \\
\end{tabular}} & \multirow{2}{*}{$\begin{array}{l}\text { DAY } \\
\text { Cup } 1\end{array}$} & \multicolumn{2}{|c|}{$(m) 1$} & \multicolumn{2}{|c|}{$(m) 2(e$} & \multicolumn{2}{|c|}{$(m) 3$} & \multicolumn{2}{|c|}{ (m) 4} & (m)5 & (m) 6 & (m)7 \\
\hline & & $\overline{0}$ & & 0 & 0 & 0 & $\overline{0}$ & 0 & 0 & & * & \\
\hline & Cup 2 & 0 & 0 & 0 & 0 & 0 & 0 & 0 & 0 & & * & $\star$ \\
\hline & Cup 3 & 0 & 0 & 0 & 0 & 0 & 0 & 0 & 0 & * & * & $\star$ \\
\hline & Cup 4 & 0 & 0 & 0 & 0 & 0 & 0 & 0 & 0 & $\star$ & * & * \\
\hline & Cup 5 & 0 & 0 & 0 & 0 & 0 & 0 & 0 & 0 & * & $\star$ & * \\
\hline & Cup 6 & 0 & 0 & 0 & 0 & 0 & 0 & 0 & 0 & $\div$ & $\div$ & $\div$ \\
\hline & Cup 7 & 0 & 0 & 0 & 0 & 0 & 0 & 0 & 0 & $\div$ & $\div \quad \div$ & $\div \quad \div$ \\
\hline & Cup 8 & 0 & 0 & 0 & 0 & 0 & 0 & 0 & 0 & $\div$ & $\div$ & $\div$ \\
\hline & Cup 9 & 0 & 0 & 0 & 0 & 0 & 0 & 0 & 0 & $\div$ & $\div$ & $\div$ \\
\hline & $\begin{array}{l}\text { Cup } \\
10\end{array}$ & 0 & 0 & 0 & 0 & 0 & 0 & 0 & 0 & $\div \quad \div$ & $\div \quad \div$ & $\div \quad \div$ \\
\hline $\begin{array}{l}\text { Contro } \\
\text { I River }\end{array}$ & $\begin{array}{l}\text { Cup } \\
11\end{array}$ & 0 & 0 & 0 & 0 & 0 & 0 & 0 & 0 & $\div \quad \div$ & $\div \quad+$ & $\div \quad+$ \\
\hline
\end{tabular}

KEY: $+=$ slight growth; $0=$ no growth; ${ }^{*}=$ growth; $(m)=$ morning; $(e)=$ evening

The data table shows the growth between 1-7 days. The data table shows that it took 4 days to grow; then the cups with the most Delta water did not grow as much as the ones with tap water.

\section{Discussion}

The results were different than we expected. I (Carolina Galvan) expected it to all grow fully because I didn't think the water would have a bad effect on the beans. I (Francesca Bardo) thought the ones in the most tap water would grow. It was just a guess. I (Valerie Culson) thought the same as Carolina Galvan. The significance of this experiment and its findings were good because we got to find out how dirty and contaminated the water was. 


\section{Acknowledgments}

We would like to acknowledge the following people: Mrs. Johnson, our Biology teacher, and the scientist from Lawrence Livermore National Laboratory, Dr. John Knezovich who came to help us. 


\title{
Does Storm Water Runoff Alter The pH and Phosphate Levels of Dry Creek?
}

Michael Leonard and JR Hynds

Teacher: Nick Crooker

Modesto High School

Modesto, CA

\section{Introduction}

Rain water runoff from city streets may become a problem to tributaries that feed major river systems. Research has found that most urban streets runoff contain heavy metals such as lead and cadmium [2].

Our interest was to find out if a recently installed storm drain will adversely alter the chemistry of the local tributary named Dry Creek.

This is important because if it is changing the chemistry of the water (especially $\mathrm{pH}$ and phosphate levels) the flora and fauna of this tributary and the Tuolumne River may be adversely affected.

\author{
Materials and Methods \\ paper \\ pencil \\ pen \\ backpack \\ camera \\ tape measure \\ test kits \\ flashlight \\ vehicle \\ jars \\ rubber boots
}

We first had to make our way down the embankment to get to the creek. We then unpacked all of our materials and placed them on the rocks by the creek.

Using the tape measure we measured thirty feet upstream and thirty feet downstream from the runoff drain pipe. We did the same test upstream, downstream and at the pipe exit.

We took the phosphate test from the box and we filled the vial with water. After this we added the two drops of solution. Then we snapped the tube which pulls in the water and we shook the tube. We compared the color of the snapper results to the color coded chart.

We took the $\mathrm{pH}$ test next. We filled the container with water, added the solution, and shook it up. We then compared the color coded chart with the color of the water in the container. 


\section{Discussion}

We expected that the runoff from the road would change the chemistry of the water, and our hypothesis was proven to be correct.

On our first visit to the river site the water was moving very slowly and it smelled like rotting eggs. The stream of water coming out of the drain was about $1 / 2$ inch wide.

We began our testing on the second visit. The only difference was that the water was coming out of the drain faster and you could see an iridescent oily film on the water's surface.

The third trip was during the first rain of the season. Because of the rain washing the oil off the new road we found lots of oil and soap suds which may have helped change the water's chemistry. The air in the vicinity still smelled of rotting eggs. A dead fish was found floating 30 feet upstream of the drain. This also corresponded with my upstream testing site.

On our final test, the creek had risen over the top of the drain making the drain disappear from sight. The rotting egg smell was no longer present. Upon further research we learned that advanced stages of cultural eutrophication [1] produces anaerobic conditions which make the gas hydrogen sulfide causing the rotting egg smell.

The results indicate that as the water comes down the creek and the runoff enters the water, the $\mathrm{pH} \&$ phosphate levels have a tendency to increase.

Our research shows an increase in $\mathrm{pH}$ and phosphate levels during storm water runoff. The question remains, will these levels adversely affect plant and animal life? Further research is necessary.

\section{References}

[1] by Mitchell K. Mark, M.S and Stapp B. William, Ph.D 1994 Field Manual for Water Quality Monitoring Thomson-Shore, Inc. Dexter, Michigan

[2] by Linden, Eugene (Time Jan. 21989 page 34) The Death of Birth

\section{Acknowledgments}

We would like to thank Mr. \& Mrs. Leonard, Mr. \& Mrs. Hynds, Mr. Crooker, Mr. Abby, and Miss. Baker. We would like to thank them because they helped us in many different ways and we are very thankful for there support and there help. 


\title{
Is There Acid Rain in Modesto?
}

\author{
San Duch \\ Teacher: Nick Crooker \\ Modesto High School \\ Modesto, CA
}

Modesto High is the oldest (116 years old) school in Modesto. Modesto High is recognized for being the most educationally advanced school in Modesto. Modesto High's population is about 2400 students.

\section{Introduction}

In my research I'm going to test the rain for acidity. Rainwater once was the purest form of water available but now is often contaminated by pollutants in the air. Air pollution is the main cause of acid rain. Traffic exhaust and smoke from factories, power stations, and fires are carried into the air. They soon acidified the clouds, pollutants combine with atmospheric moisture to form sulfurous, sulfuric, nitric, and carbonic acids. Acidified clouds may travel great distances before releasing their moisture. Acid rain kills forests and lakes, the acid disrupts the delicate balance of the lake ecosystems and eventually kills all organisms (2). For rain to be acid rain the $\mathrm{pH}$ level must be 5.5 or less, pure rain is $5.6(1)$.

Not much is known about the topic because there was no such problem as acid rain. It is very important to study acid rain. A number of species of fish have died because of acid rain. In the Northeast of the United States $95 \%$ of the lakes up there are contaminated with acid rain (1). Acid deposition may become an increasing problem and continue to endanger more plants and animal life. The purpose of my research is to see if Modesto has acid rain.

\section{Materials and Methods}

The method that was being use to test the rain water was with the Hach $\mathrm{pH}$ tester. The kit's pH scale reads from 4-10. I collected the rain with a 12 ounce glass in my backyard. Each sample was tested three times to ensure true readings. When this was completed I recorded the data. When the next rain came I repeated the procedure.

\section{Results}

Upon completing the test and the studying the results, I conclude that Modesto doesn't really have a problem with acid rain. On each test the $\mathrm{pH}$ reading was close to 6.4. Some test read 6.3 or 6.5 , this may be due to sampling error. 
Listed and graphed below are the testing results.

2nd rain storm 12-11-95 (time tested 12-12-95 7:20 pm) 1 st reading 6.4

2nd reading 6.4

3rd reading 6.4

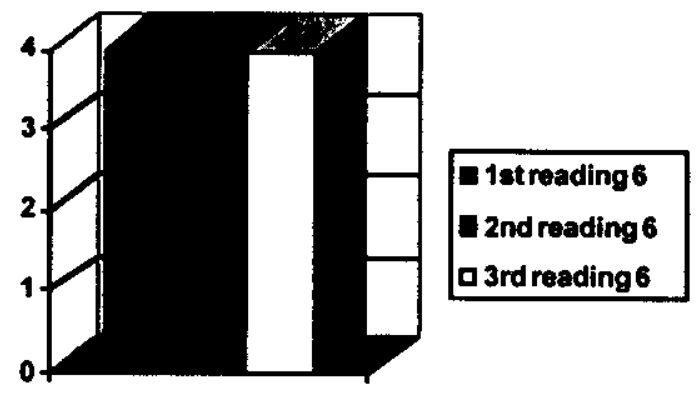

3rd rain storm 12-12-95 (time tested 12-12-95 3:35 pm) 1 st reading 6.4 2nd reading 6.4 3rd reading 6.4

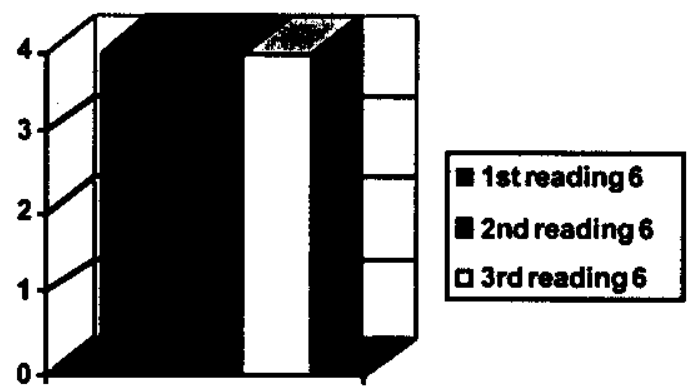

4th rain storm 12-13-95 (time tested 12-14-95 4:00 pm) 1 st reading 6.4 2nd reading 6.5 3rd reading 6.4

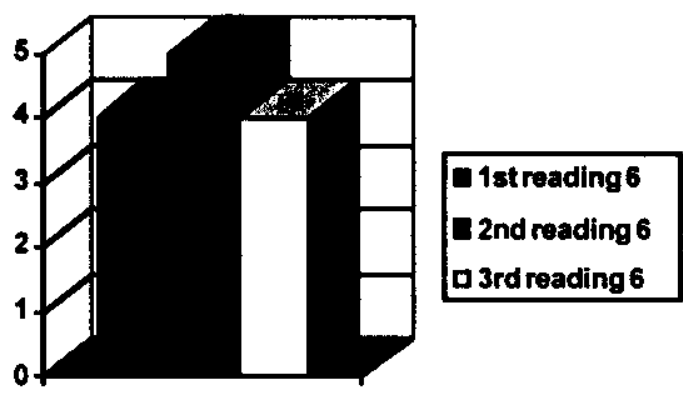


5th rain storm 12-15-95 (time tested 12-15-95 4:45 pm)

1 st reading 6.3

2nd reading 6.3

3rd reading 6.4

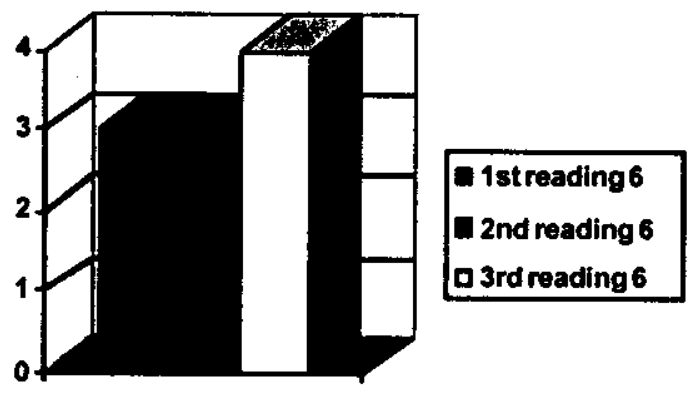

6th rain storm 12-18-95 (time tested 12-18-95 5:05 pm)

1 st reading 6.3

2nd reading 6.4

3rd reading 6.4

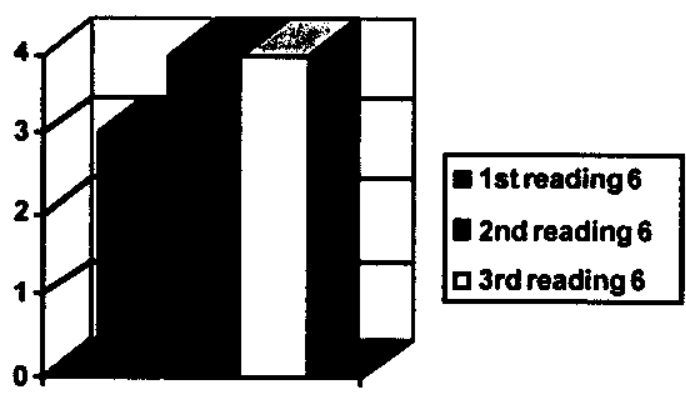

\section{Discussion}

The findings of my research are somewhat significant. In the beginning of my research I thought that Modesto would have acid rain. But for rain to be considered acid the pH level must be lower than 5.6. How could we have rain far higher in the $\mathrm{pH}$ level than pure rain? If car exhaust and smoke from factories cause acid rain why aren't we having it? One of the ways my readings on the rain can be of importance is to continue testing in the future. After all the test I have completed I can say this for a fact, "Modesto does not have acid rain."

\section{Acknowledgments}

Thanks to Mr. Crooker, Mr. Duch, and Mr. And Mrs. Leonard.

\section{References}

1. Moore, Thomas H. ( 1991) Acid Rain New Approach to Old Problem. Congressional Quarterly Inc.

2 Microsoft Encarta 95 


\title{
Use of RAPDs (Random Amplified Polymorphic DNA) to Determine Characteristics in Egeria densa
}

\author{
Amar Nijagal \\ Teacher: J. Kirk Brown \\ Tracy High School \\ Tracy, CA
}

\begin{abstract}
The San Joaquin-Sacramento Delta River System is an essential component of California's agricultural system. Egeria densa is a problematic aquatic weed in this Delta River System. With its rapid propagative ability and its photosynthetic efficiency, Egeria densa impedes water flow, causes hassle for commercial boating, and creates problems for the use of this essential river system. Egeria originates from South America and has been introduced into waterways throughout the world. Using a RAPD (Random Amplified Polymorphic DNA) analysis procedure and gel electrophoresis, biotypes of Egeria densa were characterized and contrasted. RAPD involves the use of arbitrary primers to amplify DNA fragments. Three different sources of Egeria densa were characterized; Delta Egeria, New Zealand Egeria, and Davis cultivare Egeria. Biotypes of Egeria from the Delta and New Zealand areas appeared to be more closely related to each other than to the Egeria cultivated in Davis (obtained at Davis Lumber). The similarity between Egeria densa samples will lead to effective aquatic weed controls through analysis of biological controls in areas where Egeria densa is a native aquatic weed. Continued research using the RAPDs technique will lead to possible origins of this aquatic weed and reasons why Egeria densa causes the problem it does in California.
\end{abstract}

\section{Introduction}

The Sacramento and San Joaquin Delta River System is the most important component in California's water system, allowing transportation of water for agriculture and for commercial boats. Without California's current river system, California would not be the most important area of irrigation farming in the United States (Higbee, 1958). River flow, in such a vital river system, must be efficiently maintained without need for costly pumps and water moving devices. However, there are obstructions to the river flow such as aquatic vegetation. The vegetation, such as aquatic weeds, exists in waterways and hinder water flow. Aquatic weeds, such as Egeria densa, belonging to the Hydrilla charitaceae family, create problems for people who rely on water for agriculture or transportation of goods.

Egeria densa is a problematic aquatic weed that is under observation and research since it is a weed that can be grown, exported, imported, and spread without any government regulations. Egeria, like other aquatic weeds, obstructs the flow of water and is found in great quantities in the Sacramento and San Joaquin Delta River System. Although there are control of methods of this aquatic weed, none are cost-effective. 
Egeria is a troublesome plant. It has the ability to grow nearly anywhere due to its photosynthetic efficiency, requiring very little light to carry out its photosynthetic processes. Additionally Egeria densa does not need a foundation for its growth, thus growing without the presence of soil. It reproduces very quickly from any stem portion of a plant. Egeria can grow very close to the top of the water because of its adaptive characteristics, such as its photosynthetic efficiency, thus causing problems for aquatic life that lives below it. Without sunlight penetrating through the thick cover, many plants are not able to receive the light that they require. By creating a thick cover on top of the water, acting like a pool cover, Egeria insulates and eventually increases the heat in the river (Anderson, 1995). Many organisms that rely on a specific temperature can no longer survive. It acts as a substrate for algae, assisting in the creation of a thick cover on the top of the water (Anderson, 1995). Due to such a thick cover and its highly propagative ability, Egeria hinders the flow of water through waterways, clogs propellers in boats, and causes problems for other aquatic vehicles.

Thus, scientists are now looking for methods to control Egeria. The goal of this laboratory research project is to determine genetic characteristics of Egeria densa. By understanding this aquatic weed's characteristics, conclusions can be made of the origin of this weed and its future control methods. By determining genetic characteristics of Egeria with other samples in the Western Hemisphere, differences can be determined between the samples.

RAPD (Random Amplified Polymorphic DNA) markers will be used in this research to identify the general characteristics in Egeria densa (Rafalski, 1993). By using synthetic engineered random primers (decameric oligonucleotides), DNA segments will be amplified. Depending on the characteristics of each sample, samples can be contrasted to determine origins of Egeria densa and reasons why Egeria causes such a problem in the Sacramento and SanJoaquin Delta River System.

\section{Materials and Methods}

The protocol for DNA isolation begun by acquiring Egeria densa apical shoot meristem tissue from the USDA-ARS Research Laboratory. Fresh Weight measurements were made of the tissue and the tissue was lyophilized (freezedried) overnight with the use of liquid Nitrogen. The tissue was pulverized in a mortar and pestle by keeping the tissue frozen with liquid Nitrogen. 20 volumes of CTAB extraction buffer, approximately $9 \mathrm{~mL}$, was added to the pulverized tissue and the contents were poured in a centrifuge tube. After 3 inversions during a 90 minute incubation in a $650 \mathrm{C}$ water bath, the tube was placed in a Superspeed Sorval low speed refrigerated centrifuge at $10,000 \mathrm{~g}$. for 10 minutes at $4 \infty \mathrm{C}$. The supernatant was removed and placed in a fresh tube. To the fresh tube containing the supernatant, an equal volume $(9 \mathrm{~mL})$ of a 24:1 chloroform and isoamyl solution was added. After gentle inversions the contents were centrifuged again with the same settings as the previous time. The aqueous phase was transferred in another tube and a one-tenth volume $(9 \mathrm{~mL})$ of a $10 \%$ CTAB solution was added. Again, an equal volume $(10 \mathrm{~mL})$ of a 24:1 chloroform and isoamyl mixture was added, the tubes were gently 
inverted, and centrifuged at the same settings. The tube was placed on ice for a minimum of $15 \mathrm{~min}$. The contents were centrifuged at $3000 \mathrm{~g}$. for $15 \mathrm{~min}$. at $4 \infty \mathrm{C}$, and the supernatant was drained. The DNA was resuspended by adding $4 \mathrm{~mL}$ of high salt TE, and placed in a $56 \infty \mathrm{C}$ water bath. The DNA was cooled on ice. Two volumes $(8 \mathrm{~mL})$ of $-20 \infty \mathrm{C}$ ethanol was added to the DNA solution and chilled on ice for $15 \mathrm{~min}$. The sample was centrifuged at $10,000 \mathrm{~g}$. for 10 min. at $4 \circ \mathrm{C}$. The supernatant was drained and the pellet was washed with 2 $\mathrm{mL}$ of $70 \%$ ethanol. The substance was lyophilized for $10 \mathrm{~min}$. and then $1 \mathrm{~mL}$ of TE buffer was added so that the DNA could resuspend at $4 \infty \mathrm{C}$ overnight.

By using a spectrophotometer, 3 different wavelength absorbency readings were made of a 10:1 dilution of the stock DNA solution. The readings included an absorbency of wavelengths of light at 230,260 and $280 \mathrm{~nm}$. The absorbency at $230 \mathrm{~nm}$.(A230) is designed to detect polysaccharides. The A260 was for nucleotides and the A280 was a detector of proteins. After these readings, $5 \mathrm{~mL}$ of Ribonuclease was added to the stock solution to remove any RNA, and placed in a $37 \infty \mathrm{C}$ water bath for $20 \mathrm{~min}$. $25 \mathrm{~mL}$ of $12.5 \mathrm{mM}$ EDTA, $1 / 10$ volume $(50 \mathrm{~mL})$ of $3 \mathrm{M}$ sodium acetate, and 2.5 volume $(1.25 \mathrm{~mL})$ ethanol was added to precipitate the DNA. The tube was kept frozen at $-80 \infty \mathrm{C}$ for at least 1 hour. The contents were centrifuged at $10,000 \mathrm{~g}$. for $10 \mathrm{~min}$. at $4 \infty \mathrm{C}$. The supernatant was discarded and the pellet was rinsed with ice-cold $70 \%$ ethanol. $1 \mathrm{~mL}$ of TE buffer was used to resuspend the DNA. The A230, A260, and A280 measurements were obtained and used to quantify the DNA.

The extracted DNA was then used for qualitative measurements, distinguishing the quality of the DNA fragments. A 20:1 dilution (285 mL Distilled Water/15 mL of TBE buffer) of 10X TBE buffer was prepared. A $0.7 \% 3 \mathrm{~mm}$. agarose gel was prepared along with $10.5 \mathrm{~mL}$. DNA was loaded in the gel and the gel was ran for 1 hour and 55 minutes at 60V. Pictures were taken and analyzed.

The next qualitative procedure involved the digestion of DNA with Eco RI. $5 \mathrm{mg}$ (3.86 $\mathrm{mL}$ ) of DNA was placed in a microcentrifuge tube and allowed to relax with TE buffer for 2 hours, light mixing every 30 minutes. EcoRI was added and digestion was allowed to occur for $30 \mathrm{~min}$, concluding by the inactivation using EDTA. $2 \mathrm{M}$ Sodium Acetate $(7.5 \mathrm{~mL})$ and $125 \mathrm{~mL}$ of Ethanol was added to precipitate the DNA. After the contents were precipitated, the contents were centrifuged to obtain a pellet. The supernatant was drained and TE buffer was used to remove all the DNA on the sides of the microcentrifuge tube. Another agarose gel was prepared and ran with the restriction enzyme digested DNA. A high molecular weight standard was used also to estimate DNA molecular weight. Through these qualitative tests, the quality of DNA was determined.

The RAPD (Random Amplified Polymorphic DNA) was the next procedure that was used. To begin, the RAPD procedures involved many extracted DNA samples, and the following table shows how they will be referred to. 


\begin{tabular}{|l|l|}
\hline DNA (Date) & Referred to as... \\
\hline 1st Shoot DNA extraction (7/10/95) & Shoot \\
\hline Dilutions of 7/10 Shoot extraction & Shoot I, Shoot II, Shoot III \\
\hline 1st Root DNA extraction (7/10/95) & Root \\
\hline Dilutions of 7/10 Root extraction & Root l, Root II, Root III \\
\hline $\begin{array}{l}\text { Shoot DNA from Delta Egeria } \\
\text { (7/20/95) }\end{array}$ & Delta 1 \\
\hline $\begin{array}{l}\text { Shoot DNA from Delta Egeria } \\
(7 / 20 / 95)\end{array}$ & Delta 2 \\
\hline $\begin{array}{l}\text { Shoot DNA from Delta Egeria } \\
(7 / 20 / 95)\end{array}$ & Delta 3 \\
\hline $\begin{array}{l}\text { Shoot DNA from Delta Egeria } \\
\text { (7/20/95) }\end{array}$ & Delta 4 \\
\hline $\begin{array}{l}\text { Shoot DNA from Davis Lumber Egeria } \\
\text { (7/20/95) }\end{array}$ & D. Lumber \\
\hline $\begin{array}{l}\text { Shoot DNA from New Zealand Egeria: } \\
\text { Sample A (7/26/95) }\end{array}$ & NZ(A) \\
\hline $\begin{array}{l}\text { Shoot DNA from New Zealand Egeria: } \\
\text { Sample B (7/26/95) }\end{array}$ & NZ (B) \\
\hline
\end{tabular}

The process began by diluting Egeria shoot genomic DNA using a 20:1 dilution ratio. Master mixes were prepared, including appropriate amounts of Distilled water $(18 \mathrm{~mL})$, PCR buffer $(2.5 \mathrm{~mL})$, Adenine $(0.5 \mathrm{~mL})$, Thymadine $(0.5 \mathrm{~mL})$, Guanine $(0.5 \mathrm{~mL})$, Cytosine $0.5 \mathrm{~mL})$, and DNA or primer per reaction. The DNA was calculated to be $50 \mathrm{ng}$. per reaction. The master mixes were distributed in the appropriate tubes and $35 \mathrm{~mL}$ of mineral oil was added to each. The tubes were loaded in a Thermal Cycler and brought up to $94 \infty \mathrm{C}$. After about $2 \mathrm{~min}$. at this temperature, $2 \mathrm{~mL}$ of Taq-polymerase was added to each tube. The Thermal Cycler was allowed to run for 40 cycles with the following sequence of temperatures; $94 \infty \mathrm{C}, 37 \infty \mathrm{C}$, and $72 \infty \mathrm{C}$. The cycles took approximately 3 hours. During this process a $0.5 \mathrm{X}$ dilution was made by using $2,090 \mathrm{~mL}$ of distilled water and $110 \mathrm{~mL}$ of TBE buffer. This buffer was used to produce a $1.5 \%$ agarose gel. The gel was allowed to solidify and after the Thermal Cycler was completed, $0.6 \mathrm{~mL}$ of $6 \mathrm{X}$ loading dye was added to each tube. The agarose gel was loaded and ran for approximately 2 hours at 120V. After the approximate time of 2 hours, the gel was trimmed and placed in a $0.5 \mathrm{mg} / \mathrm{mL}$ solution of Ethidium Bromide ( $100 \mathrm{~mL}$ of distilled water and $50 \mathrm{~mL}$ of EtBr). The gel was mixed at $60 \mathrm{revs} / \mathrm{min}$ for $30 \mathrm{~min}$. and was destained using distilled water for the same amount of time. This was then taken to a UV light source for analysis.

The RAPD reaction and analysis explained above was repeated for the same shoot genomic DNA, except that 3 different dilutions were used. All dilutions were 20:1 dilutions, however they were done separately. This was analyzed through the use of RAPDs and an elctrophoretic agarose gel.

The research continued by extracting more Egeria shoot genomic DNA obtained from the Delta. Four different extraction were done of Delta Egeria, 
and one was done from Egeria obtained from Delta Lumber. The procedure for isolation is a condensed version of the previously described DNA isolation protocol. This can be referred to in Appendix A, along with the previous protocol. The four Delta Egeria extractions, one Davis Lumber Egeria extraction, and two previous root and shoot extractions were analyzed through RAPDs. However, during this RAPDs procedure, $5 \mathrm{ng}$. of DNA was used because the DNA was diluted by a 10:1 ratio.

The RAPD procedure was again used with 4 DNA's and 10 primers. 2 Delta DNA extractions were used, 1 Davis Lumber extraction, and 1 previously extracted shoot DNA. The results were analyzed and were compared with other RAPD results. Egeria DNA from New Zealand was extracted with the condensed DNA isolation procedure (second procedure in Appendix A) and used for RAPDs analysis. The results were analyzed and again used comparatively.

After isolation of genomic DNA from New Zealand Egeria, RAPD reactions were done with 8 primers and 2 samples of Delta Egeria, 1 sample of Davis Lumber Egeria, and 2 samples of New Zealand Egeria. After analysis, 3 of these primers were repeated using the same DNA samples and completed the RAPD work with New Zealand DNA.

\section{Results}

After DNA extraction and RNAase treatment, meant to remove RNA and DNAases, spectrophotometer readings were done. Using the A260 reading of 1.649 and a 10:1 dilution before RNAase treatment, the DNA was quantitized to be approximately $824.5 \mathrm{mg}$. After the RNAase treatment the A260 read to be 1.297 , and with a 20:1 dilution the DNA was calculated to be $648.5 \mathrm{mg}$.

The DNA used for qualitative tests, shown in Figures 2.1 and 2.2, had an estimated molecular weight of 16.6 kilobases. Figures $3.1,3.2$, and 3.3 in Appendix $B$ show the results of the preliminary RAPD reactions. The pictures are labeled by the primer used in each lane. The DNA was ran in pairs, thus two lanes of similar DNA per primer. The high molecular weight standard, as labeled, is shown in lane 13.

Another RAPD reaction and gel was run using 3 different DNAdilutions. Depending on the A260 reading of each dilution, the amount of DNA used in each RAPD reaction varied. The Shoots I dilution required $0.4 \mathrm{~mL}$ of DNA per tube with an A260 reading of 2.80 . The Shoots II dilution required $0.7 \mathrm{~mL}$ of DNA per tube with an A260 reading of 1.46 , and Shoots III required $0.6 \mathrm{~mL}$ of DNA per tube with an A260 of 1.67. The RAPD reactions results are seen in Figures 4.1, 4.2, and 4.3 in Appendix B.

A separate DNA isolation was performed, including 4 delta Egeria DNA extractions and 1 Davis Lumber Egeria DNA extraction. The following shows the spectrophotometer readings of each Egeria DNA extraction. These figures will be used to compute the amount of stock solution necessary for the RAPD reactions. 


\begin{tabular}{|l|l|l|l|l|l|l|}
\hline Egeria densa & A280 & A260 & $\mathbf{2 8 0 / 2 6 0}$ & $\mathbf{2 6 0 / 2 8 0}$ & Stock & $10: 1$ \\
\hline Delta 1 & 0.076 & 0.125 & 0.5383 & 1.8576 & $0.8 \mathrm{~mL}$ & $8.0 \mathrm{~mL}$ \\
\hline Delta 2 & 0.1548 & 0.258 & 0.5443 & 1.8373 & $0.39 \mathrm{~mL}$ & $3.9 \mathrm{~mL}$ \\
\hline Delta 3 & 0.1538 & 0.2704 & 0.5314 & 1.8817 & $0.37 \mathrm{~mL}$ & $3.7 \mathrm{~mL}$ \\
\hline D. Lumber & 0.1466 & 0.2541 & 0.5348 & 1.8699 & $0.39 \mathrm{~mL}$ & $4.0 \mathrm{~mL}$ \\
\hline Delta 4 & 0.3174 & 0.5893 & 0.5244 & 1.9069 & $0.17 \mathrm{~mL}$ & $1.7 \mathrm{~mL}$ \\
\hline
\end{tabular}

When preparing the master mixes a miscalculation occurred and the amount required of the stock solution was used from the diluted solution. This reducing the quantity of DNA by 10 times, resulting in $5 \mathrm{ng}$ per reaction. The primers used were C01, C02, G02, G04, R01, and R02. Figures 5.1, 5.2, and 5.3 in Appendix $B$ show these results.

The RAPD procedure was again repeated with Delta 1, Delta 2, Davis Lumber, and the Shoot DNA extracted during the first DNA extraction. 10 primers (C04, $\mathrm{C} 05, \mathrm{C} 06, \mathrm{C} 11, \mathrm{C15}, \mathrm{G} 11, \mathrm{G} 17, \mathrm{R} 06, \mathrm{R} 11$, and T4) were used in this analysis. These results can be seen as Figures 6.1, 6.2, and 6.3 in Appendix B.

Two additional DNA extraction was performed from Egeria shoot tissue obtained from New Zealand. Sample 1 was a closed shoot tip, measuring to have a fresh wt. of $260 \mathrm{mg}$. Sample 2 was an open shoot tip, measuring to have a fresh wt. of $330 \mathrm{mg}$. This DNA was extracted using the second extraction protocol described in Appendix B.

The RAPD reactions that were performed using New Zealand DNA samples, A and $B$, were used the following 8 primers; C04, C05, C06, C11, C15, G11, G17, R06, R11, T4. After the first RAPD reaction, three primers, C5, C11, and R2, were repeated and can be seen as Figure 8.1. Figures 7.1, 7.2, and 7.3 in Appendix B show the RAPD reactions performed with the 5 DNA, including New Zealand DNA samples, and 8 primers.

\section{Discussion}

The first qualitative test (Figure 1.1 in Appendix B) of the isolated genomic DNA shows a thick band, representing large pieces of DNA. After restriction digestion of the genomic DNA (Figures 2.1 and 2.2, Appendix B), the agarose gel shows a streak indicating the presence of different molecular weight DNA fragments. For the first DNA extraction, the analysis showed the good quality of extracted Egeria densa genomic DNA.

RAPDs is a procedure that provides general characteristics of DNA which can be used to contrast DNA. Banding patterns that are produced show how well a specific primer worked with the DNA. The more sites there are where the primer can anneal, the brighter the band will appear, resulting from more amplified DNA. 
The first RAPD analysis (Figures 3.1, 3.2, and 3.3 in Appendix B), done on July 13, 1995, showed little banding. Only R02 in TIER I and R01, R02, and R04 in TIER II showed banding. Two samples of the same DNA were ran with each primer, however the results do not show the expected similar paired banding patterns. Similar banding patterns were expected to occur between Shoot and Root DNA, since both were obtained from the same source. The unclear and indistinct banding patterns, attributed to pipetting errors and miscalculations, do not show any conclusive evidence.

The second RAPD analysis (Figures 4.1, 4.2, and 4.3 in Appendix B) showed similar results as the first RAPD analysis, however, the shoots indicated more bands than did the roots. Although three samples of the same DNA were ran with every primer, the results did not show the expected banding patterns in triplets. Due to the inconsistencies of the results valid conclusions could not be drawn.

At this point in this research, it was decided that further Root DNA extraction would cease. By judging the qualitative analysis gels and the $A 230$ readings (wavelength absorbed by polysaccharides) of extracted Root DNA it was determined that root tissue contained too many polysaccharides, since DNA isolation protocols did not account for removal of polysaccharides. The original hypothesis behind the use of root tissue was to reduce the amount of algae DNA isolated with the Egeria DNA. Judging by the shoot tissue, this did not show to be a problem and further root experimentation was unnecessary.

By coincidence a discovery was made in the preparation of RAPD reactions. Prior to this point $50 \mathrm{ng}$. of DNA per RAPD reaction was being used. A slight miscalculation led to an inadvertent 10:1 dilution, amounting to $5 \mathrm{ng}$. of DNA per reaction. After noticing successful results, it was speculated that too much DNA was placed in the initial RAPD reaction, causing indistinguishable results.

Using C01, C02, G02, G04, R01, and R02 primers, the following RAPDs analysis compared two different sources of Egeria (shown as Figures 5.1, 5.2, and 5.3 in Appendix B). Delta Egeria (including Shoot and Root) and Davis Lumber Egeria were compared. The $\mathrm{C} 01$ and $\mathrm{C} 02$ primers show one distinct band in all Delta Egeria, which Davis Lumber Egeria lacks. The apparent pattern of 3 bands produced by the G02 primer in Delta Egeria, is not present in the Davis Lumber Egeria, where it actually lacks the first band. R01 and R02 primers gave more viable results. R01 shows similar patterns between all the Egeria samples. R02 shows very distinct and clear banding patterns. The interesting part is that the Davis Lumber Egeria does not show the first distinct band that the Delta Egeria shows, supporting the hypothesis that the Delta and Davis Lumber Egeria are of different origin.

The next RAPD reactions (Figures 6.1, 6.2, and 6.3 in Appendix D), made use of Delta and Davis Lumber with 10 different primers. The $\mathrm{C0} 4$ primer shows a totally different banding pattern associated with Davis Lumber Egeria compared to the Delta Egeria. The CO5 primer shows a distinct single band for Delta Egeria, and along with the $\mathrm{CO} 6$ show a difference by the lack of bands for Davis 
Lumber Egeria.. The $\mathrm{C} 11$ and $\mathrm{C} 15$ primers show differences, the $\mathrm{C} 15$ primer's bright bands with Delta Egeria are not present in Davis Lumber Egeria. The differences created by the primers support the claim that Egeria from the Delta and Egeria from Davis Lumber are genetically different.

The RAPD analysis on July 27, 1995 (Figures 7.1, 7.2, and 7.3 in Appendix D) shows New Zealand Egeria, Davis Lumber Egeria, and Delta Egeria. The banding pattern shown by the $\mathrm{C} 5$ primer does not show good results due to the fact that one Delta sample shows no banding (Lane 1), while the other shows 2 distinct bands. The Davis Lumber does not show any bands with the use of the C5 primer, however both New Zealand samples show one bright band. The same scenario follows for the C11 primer, which only shows banding patterns for one of the two Delta Egeria samples. The Davis Lumber Egeria shows a couple faint bands that can not be read distinctly. The New Zealand samples show a smear without distinct bands. The C15 primer showed very distinct bands contrasting all three Egeria samples. The Delta Egeria showing distinct patterns, contrasting to the Davis Lumber Egeria which is missing the primary bands. The New Zealand also contrasts, lacking the smaller DNA fragments, that both Davis Lumber and Delta Egeria show. The G17 primer did not show distinct banding patterns, however showing numerous faint bands in the Delta and Davis Lumber Egeria, not present in the New Zealand Egeria. The R1 primer, shown on TIER II, shows to be different between both Delta samples and both New Zealand samples, revealing an inconsistency. The same holds true for the previously successful $R 2$ primer, which had shown similar results between all Delta samples. The $\mathrm{R} 2$ primer was to be repeated along with the C5 and $\mathrm{C} 11$ primers in order to confirm or deny previous RAPD results. Contrasting all three Egeria samples, the T4 primer shows two distinct bands for the Delta samples, no distinct bands for the Davis Lumber Egeria sample, and one distinct band for New Zealand Egeria.

The C5, C11, and R2 primers were repeated (Figure 8.1 shown in Appendix B), in order to affirm or deny the previous RAPD reaction's results. No longer showing inconsistent results, the C5 primer produced one large, distinct band in both Delta and New Zealand Egeria, while producing a small smear in Davis Lumber Egeria, indicating small fragments of DNA. The C11 primer failed as a viable primer for the second time, and was discarded for analysis. Showing contrast between the Davis Lumber Egeria from Delta and New Zealand Egeria, the R2 primer produced similar banding patterns in both Delta and New Zealand samples, characterized by 3 bright bands, however, brighter bands appeared in Delta Egeria than in New Zealand Egeria. The Davis Lumber showed one faint band indicating a small fragment of DNA.

The following is an interpretation by using Statistical Cluster Analysis from the results, compiled from the presence or absence of a band. Interpreting the tree shows that all three Egeria samples are characterized differently, however the New Zealand and Delta Egeria are more closely related to each other than to the Davis Lumber. 


\section{Conclusions}

Egeria densa is a problematic weed in the Sacramento-San Joaquin Delta River System. The negative impacts by impeding water flow and hindering commercial boating make it necessary for research to be done on this aquatic weed. The research was designed to characterize biotypes of Egeria densa and lead to origins of the aquatic weed. With the origins determined using RAPD results, biological control methods can be researched and experimented within the Delta river System

Using the results obtained it is possible to conclude that the Delta and New Zealand Egeria share genetic similarities. Speculating with this conclusion, it can be said that these two sources of Egeria could have originated from the same area, since both plants are not native to their given areas. If an origin can be determined of both samples then it could be used to identify effective biological control methods. The Davis Lumber Egeria, found to be cultivated in Davis, is shown to have very few similarities with the other two biotypes of Egeria. Knowing that the only type of Egeria found in the US and New Zealand is Male-Dioecious (Single Sex), no sexual reproduction or variability can occur, indicating that New Zealand and Delta Egeria come from a similar origin.

These results can be used to find effective bio-control methods. For example, if a bug is found to control Egeria in South America, RAPD analysis can be used to see how the New Zealand, Delta, and South America Egeria densa contrast. If there is little contrast seen through the RAPD analysis, then it can be hypothesized that the bug can control Egeria in the Delta and New Zealand as it does in South America, improving situations for commercial bating and river flow.

The characterizing of Egeria densa will also allow for understanding biotypes of Egeria. By contrasting biotypes, we can understand why Egeria causes the problem it does in the Sacramento-San Joaquin Delta River System. The use of RAPDs analysis for contrast will help to find an efficient biological control method.

Expanding on the current RAPD analysis research can include the experimentation of different control methods. RAPD analysis can even involve the 100's of other primers available, each revealing different characteristics of Egeria densa. Although a lengthy task, portions of the Egeria densa genome can be sequenced for comparison of different biotypes. The main goal of all the research is to eventually find the most efficient biological control for aquatic weeds in California. This is the primary focus of this RAPD analysis research. 


\section{Appendix A: Protocols for genomic DNA isolation}

\section{Protocol 1: Used for Shoot, Root, D. Lumber, and Delta 4, DNA extractions}

1. Remove the young growing portions of Egeria, record fresh weights, and lyophilize to dryness.

2. Determine weights of lyophilized tissue.

3. Place tissue in a pre-chilled mortar. Add liquid nitrogen to the tissue and when the liquid nitrogen has dissipated, grind the tissue to a find powder with a pre-chilled pestle.

4. Allow the frozen mortar containing the frozen tissue to sit at room temperature until the ice on the exterior of the mortar shows signs of thawing. Make sure that the tissue remains frozen at all times.

5. Add 10 volumes (volume:dry weight) of extraction buffer to the frozen tissue.

6. Pulverize the tissue with a pestle.

7. Transfer the pulverized tissue to a test tube and incubate at $65^{\circ} \mathrm{C}$ for 90 minutes. Every $30 \mathrm{~min}$, gently invert the tube several times.

8. After the incubation period, centrifuge the sample at $10,000 \mathrm{~g}$ for $10 \mathrm{~min}$. at $4^{*} \mathrm{C}$.

9. Decant the supernatant into a fresh test tube and discard the remaining pellet.

10. Add an equal volume of a solution of chloroform and isoamyl alcohol made up to a ratio of $24: 1$, respectively, to the supernatant.

11. Gentiy invent the tube until the solution is homogeneous.

12. Centrifuge the chloroform mixture at $10,000 \mathrm{~g}$ for $10 \mathrm{~min}$ at $4^{\circ} \mathrm{C}$.

13. Transfer the aqueous phase (upper phase) to a fresh test tube.

14. Add $1 / 10$ volume of the $10 \%$ CTAB solution to the aqueous phase.

15. Repeat steps 10 to 13 .

16. To the aqueous phase add an equal volume of ice-cold isopropanol.

17. Place the tube on ice for at least $15 \mathrm{~min}$.

18. Centrifuge the sample at $3000 \mathrm{~g}$ for $15 \mathrm{~min}$ at $4^{\circ} \mathrm{C}$. The pellet should contain the DNA.

19. Resuspend the DNA in $4 \mathrm{~mL}$ of high salt TE. Place the tube in a $56^{\circ} \mathrm{C}$ waterbath to aid in the dissolution of the DNA.

20. After the DNA has dissolved, place on ice to cool.

21. Add two volumes of ethanol chilled to $-20^{\circ} \mathrm{C}$ to the DNA solution.

22. Chill the sample on ice for at least $15 \mathrm{~min}$.

23. Centrifuge the DNA preparation at $10,000 \mathrm{~g}$ for $10 \mathrm{~min}$ at $4^{\circ} \mathrm{C}$.

24. Washed the DNA pellet once with $70 \%$ ethanol and then lyophilize to dryness.

25. Resuspend the lyophilized DNA in TE at $4^{\circ} \mathrm{C}$ overnight.

26. Determine the $A_{230} A_{260}, A_{280}$ of the DNA sample.

27. Quantify the DNA.

28. Remove contaminating RNA by adding DNAse-free Ribonuclease $A$ to a final concentration of $100 \mu \mathrm{g} / \mathrm{mL}$.

29. Incubate at $37^{\circ} \mathrm{C}$ for $20 \mathrm{~min}$.

30. Add EDTA to a final concentration of $12.5 \mathrm{mM}$ to inactivate the enzyme.

31. Add $1 / 10$ volume of a $3 \mathrm{M}$ sodium acetate solution and 2.5 volume ice-cold ethanol to the RNA-free DNÁ. 
32. Place tube at $-70^{\circ} \mathrm{C}$ for at least 1 hour.

33. Centrifuge DNA preparation at $10,000 \mathrm{~g}$ for $10 \mathrm{~min}$ at $4^{\circ} \mathrm{C}$.

34. Discard the supernatant.

35. Rinse the pellet once with ice-cold $70 \%$ ethanol.

36. Resuspend the pellet in $1 \mathrm{~mL}$ of TE.

37. Repeat steps 31-36.

38. Again determine the $A_{230} A_{260}$, and $A_{280}$.

39. Quantify the DNA.

Protocol 2: Used for Delta 1, Delta 2, Delta 3, NZ (A), and NZ (B). DNA extractions

1. $500 \mathrm{mg}$. fresh weight of Egeria densa was obtained from the Aquatic Weed Research Facility.

2. Liquid Nitrogen was used to freeze the tissue and with the use of a mortar and a pestle, he tissue was pulverized into a fine powder.

3. $5 \mathrm{~mL}$ of CTAB extraction buffer and a $0.1 \%$ Betamer-cap was added to the pulverized tissue.

4. The liquid was poured into a $6 \mathrm{~mL}$ centrifuge tube.

5. The tube was incubated at $60 \infty_{\infty} \mathrm{C}$ for 1 hour.

6. The contents were placed in a centrifuge for 10 minutes at $4 \infty \mathrm{C}$ and 10,000 rpm.

7. Approximately $4 \mathrm{~mL}$ of the supernatant was removed and $2 \mathrm{~mL}$ was placed in $2-6 \mathrm{~mL}$ centrifuge tubes.

8. An equal volume of a $24: 1$ chloroform/isoamyl mixture was added and gently mixed.

9. The contents were spun for $10 \mathrm{~min}$. at $4 \infty \mathrm{C}$ and $8,000 \mathrm{rpm}$.

10. The aqueous phase $(1.5 \mathrm{~mL})$ of each tube was removed and placed in fresh tubes.

11. $150 \mathrm{~mL}$ of sodium acetate and $1.5 \mathrm{~mL}$ of isoproponal were added to each tube.

12. The contents were allowed to freeze overnight.

13. The contents were taken out and spun for $10 \mathrm{~min}$. at $4 \infty \mathrm{C}$ and $8,000 \mathrm{rpm}$

14. The supernatant was drained.

15. $70 \%$ alcohol $(1 \mathrm{~mL}$ ) was used to transfer the contents of one $6 \mathrm{~mL}$ tube to one microfuge tube.

16. This microfuge tube was spun down for $10 \mathrm{~min}$. at $4 \infty \mathrm{C}$ and $8,000 \mathrm{rpm}$.

17. The pellet was drained and allowed to dry in a vacuum for 10 minutes.

18. $100 \mathrm{~mL}$ of $10 \mathrm{mM}$ TE buffer and $5 \mathrm{~mL}$ of RNAase (DNAase Free) was added and allowed to incubate at $37 \infty \mathrm{C}$ for $30 \mathrm{~min}$.

19. The tubes were removed from the water bath and chilled slightly.

20. $30 \mathrm{~mL}$ of $2 \mathrm{M}$ sodium acetate and $300 \mathrm{~mL}$ of $100 \%$ ethanol was added.

21. The contents were allowed to freeze for 2 hours.

22. The tube was taken out and allowed to be spun for $10 \mathrm{~min}$. at $4 \infty \mathrm{C}$ and $8,000 \mathrm{rpm}$.

23. The pellet was drained and rinsed with $70 \%$ ethanol.

24. The contents were spun for $10 \mathrm{~min}$. at $4 \infty \mathrm{C}$ and $8,000 \mathrm{rpm}$.

25. The tube was allowed to dry in a vacuum for $10 \mathrm{~min}$.

26. $100 \mathrm{~mL}$ of TE buffer was added and the tube was placed on ice for $30 \mathrm{~min}$. 
27. Dilutions were made and spectrophotometer readings were obtained.

\section{Appendix B: Master Mix Tables}

July 13, 1995 RAPD reactions (1 DNA/6 Primers)

\begin{tabular}{|l|l|l|}
\hline & Per reaction & Master Mix \\
\hline Distilled H20 & $18.0 \mathrm{~mL}$ & $252.0 \mathrm{~mL}$ \\
\hline PCR Buffer & $2.5 \mathrm{~mL}$ & $35.0 \mathrm{~mL}$ \\
\hline Adenine & $0.5 \mathrm{~mL}$ & $7.0 \mathrm{~mL}$ \\
\hline Thymine & $0.5 \mathrm{~mL}$ & $7.0 \mathrm{~mL}$ \\
\hline Guanine & $0.5 \mathrm{~mL}$ & $7.0 \mathrm{~m}$ \\
\hline Cytosine & $0.5 \mathrm{~mL}$ & $7.0 \mathrm{~mL}$ \\
\hline Shoot DNA & $1.0 \mathrm{~mL}$ & $14.0 \mathrm{~mL}$ \\
\hline Primer & $1.0 \mathrm{~mL}$ & NA \\
\hline Taq & $0.2 \mathrm{~mL}$ & NA \\
\hline
\end{tabular}

July 17, 1995 RAPD reactions (3 DNA dilutions/6 Primers)

\begin{tabular}{|c|c|c|c|c|c|c|}
\hline & Shoot I & Shoot II & Shoot III & Roots I & Roots II & Roots III \\
\hline $\begin{array}{l}\text { Distille } \\
\text { d } \mathrm{H} 20\end{array}$ & $\begin{array}{l}18 \\
\mathrm{~mL} / 162 \\
\mathrm{~mL}\end{array}$ & $\begin{array}{l}18 \mathrm{~mL} / 162 \\
\mathrm{~mL}\end{array}$ & $\begin{array}{l}18 \mathrm{~mL} / 162 \\
\mathrm{~mL}\end{array}$ & $\begin{array}{l}18 \mathrm{~mL} / 162 \\
\mathrm{~mL}\end{array}$ & $\begin{array}{l}18 \\
\mathrm{~mL} / 162 \\
\mathrm{~mL}\end{array}$ & $\begin{array}{l}18 \\
\mathrm{~mL} / 162 \\
\mathrm{~mL}\end{array}$ \\
\hline $\begin{array}{l}\text { PCR } \\
\text { Buffer }\end{array}$ & $\begin{array}{l}2.5 \\
\mathrm{~mL} / 22.5 \\
\mathrm{~mL}\end{array}$ & $\begin{array}{l}2.5 \\
\mathrm{~mL} / 22.5 \\
\mathrm{~mL}\end{array}$ & $\begin{array}{l}2.5 \\
\mathrm{~mL} / 22.5 \\
\mathrm{~mL}\end{array}$ & $\begin{array}{l}2.5 \\
\mathrm{~mL} / 22.5 \\
\mathrm{~mL}\end{array}$ & $\begin{array}{l}2.5 \\
\mathrm{~mL} / 22.5 \\
\mathrm{~mL}\end{array}$ & $\begin{array}{l}2.5 \\
\mathrm{~mL} / 22.5 \\
\mathrm{~mL}\end{array}$ \\
\hline & $\begin{array}{l}0.5 \mathrm{~mL} / 4.5 \\
\mathrm{~mL}\end{array}$ & $\begin{array}{l}0.5 \mathrm{~mL} / 4.5 \\
\mathrm{~mL}\end{array}$ & $\begin{array}{l}0.5 \mathrm{~mL} / 4.5 \\
\mathrm{~mL}\end{array}$ & $\begin{array}{l}0.5 \mathrm{~mL} / 4.5 \\
\mathrm{~mL}\end{array}$ & $\begin{array}{l}0.5 \mathrm{~mL} / 4.5 \\
\mathrm{~mL}\end{array}$ & $\begin{array}{l}0.5 \mathrm{~mL} / 4.5 \\
\mathrm{~mL}\end{array}$ \\
\hline $\begin{array}{l}\text { Thymin } \\
\text { e }\end{array}$ & $\begin{array}{l}0.5 \mathrm{~mL} / 4.5 \\
\mathrm{~mL}\end{array}$ & $\begin{array}{l}0.5 \mathrm{~mL} / 4.5 \\
\mathrm{~mL}\end{array}$ & $\begin{array}{l}0.5 \mathrm{~mL} 4.5 \\
\mathrm{~mL}\end{array}$ & $\begin{array}{l}0.5 \mathrm{~mL} / 4.5 \\
\mathrm{~mL}\end{array}$ & $\begin{array}{l}0.5 \mathrm{~mL} / 4.5 \\
\mathrm{~mL}\end{array}$ & $\begin{array}{l}0.5 \mathrm{~mL} / 4.5 \\
\mathrm{~mL}\end{array}$ \\
\hline $\begin{array}{l}\text { Guanin } \\
\text { e }\end{array}$ & $\begin{array}{l}0.5 \mathrm{~mL} / 4.5 \\
\mathrm{~mL}\end{array}$ & $\begin{array}{l}0.5 \mathrm{~mL} / 4.5 \\
\mathrm{~mL}\end{array}$ & $\begin{array}{l}0.5 \mathrm{~mL} / 4.5 \\
\mathrm{~mL}\end{array}$ & $\begin{array}{l}0.5 \mathrm{~mL} / 4.5 \\
\mathrm{~mL}\end{array}$ & $\begin{array}{l}0.5 \mathrm{~mL} / 4.5 \\
\mathrm{~mL}\end{array}$ & $\begin{array}{l}0.5 \mathrm{~mL} / 4.5 \\
\mathrm{~mL}\end{array}$ \\
\hline $\begin{array}{l}\text { Cytosi } \\
\text { ne }\end{array}$ & $\begin{array}{l}0.5 \mathrm{~mL} 4.5 \\
\mathrm{~mL}\end{array}$ & $\begin{array}{l}0.5 \mathrm{~mL} / 4.5 \\
\mathrm{~mL}\end{array}$ & $\begin{array}{l}0.5 \mathrm{~mL} / 4.5 \\
\mathrm{~mL}\end{array}$ & $\begin{array}{l}0.5 \mathrm{~mL} / 4.5 \\
\mathrm{~mL}\end{array}$ & $\begin{array}{l}0.5 \mathrm{~mL} / 4.5 \\
\mathrm{~mL}\end{array}$ & $\begin{array}{l}0.5 \mathrm{~mL} / 4.5 \\
\mathrm{~mL}\end{array}$ \\
\hline DNA & $\begin{array}{l}0.4 \\
\mathrm{~mL} / 3.6 \mathrm{~mL}\end{array}$ & $\begin{array}{l}0.7 \mathrm{~mL} / 6.3 \\
\mathrm{~mL}\end{array}$ & $\begin{array}{l}0.6 \mathrm{~mL} / 5.4 \\
\mathrm{~mL}\end{array}$ & $\begin{array}{l}0.5 \mathrm{~mL} / 4.5 \\
\mathrm{~mL}\end{array}$ & $\begin{array}{l}0.6 \mathrm{~mL} / 5.4 \\
\mathrm{~mL}\end{array}$ & $\begin{array}{l}0.4 \mathrm{~mL} 4.0 \\
\mathrm{~mL}\end{array}$ \\
\hline Primer & $1 \mathrm{~mL}$ & $1 \mathrm{~mL}$ & $1 \mathrm{~mL}$ & $1 \mathrm{~mL}$ & $1 \mathrm{~mL}$ & $1 \mathrm{~mL}$ \\
\hline $\mathrm{Taq}$ & $0.2 \mathrm{~mL}$ & $0.2 \mathrm{~mL}$ & $0.2 \mathrm{~mL}$ & $0.2 \mathrm{~mL}$ & $0.2 \mathrm{~mL}$ & $0.2 \mathrm{~mL}$ \\
\hline
\end{tabular}


July 21, 1995 RAPD reactions (7 DNA samples/6 primers)

\begin{tabular}{|l|l|l|l|l|l|l|}
\hline & CO1 & CO2 & G02 & GO4 & RO1 & $R$ RO2 \\
\hline Distilled Water & $17.6 / 158$ & $17.6 / 158$ & $17.6 / 158$ & $17.6 / 158$ & $17.6 / 15$ & $17.6 / 158$ \\
\hline PCR Buffer & $2.5 / 22.5$ & $2.5 / 22.5$ & $2.5 / 22.5$ & $2.5 / 22.5$ & $2.5 / 22.5$ & $2.5 / 22.5$ \\
\hline Cytosine & $0.5 / 4.5$ & $0.5 / 4.5$ & $0.5 / 4.5$ & $0.5 / 4.5$ & $0.5 / 4.5$ & $0.5 / 4.5$ \\
\hline Guanine & $0.5 / 4.5$ & $0.5 / 4.5$ & $0.5 / 4.5$ & $0.5 / 4.5$ & $0.5 / 4.5$ & $0.5 / 4.5$ \\
\hline Adenine & $0.5 / 4.5$ & $0.5 / 4.5$ & $0.5 / 4.5$ & $0.5 / 4.5$ & $0.5 / 4.5$ & $0.5 / 4.5$ \\
\hline Thymine & $0.5 / 4.5$ & $0.5 / 4.5$ & $0.5 / 4.5$ & $0.5 / 4.5$ & $0.5 / 4.5$ & $0.5 / 4.5$ \\
\hline Guanine & $0.5 / 4.5$ & $0.5 / 4.5$ & $0.5 / 4.5$ & $0.5 / 4.5$ & $0.5 / 4.5$ & $0.5 / 4.5$ \\
\hline Primer & $1.0 / 9.0$ & $1.0 / 9.0$ & $1.0 / 9.0$ & $1.0 / 9.0$ & $1.0 / 9.0$ & $1.0 / 9.0$ \\
\hline DNA & & & & & & \\
\hline Delta 1-7/20 & $1(1 \mathrm{X})$ & $1(1 \mathrm{X})$ & $1(1 \mathrm{X})$ & $1(1 \mathrm{X})$ & $1(1 \mathrm{X})$ & $1(1 \mathrm{X})$ \\
\hline Delta 2-7/20 & $0.5(1 \mathrm{X})$ & $0.5(1 \mathrm{X})$ & $0.5(1 \mathrm{X})$ & $0.5(1 \mathrm{X})$ & $0.5(1 \mathrm{X})$ & $0.5(1 \mathrm{X})$ \\
\hline Delta 3-7/20 & $0.5(1 \mathrm{X})$ & $0.5(1 \mathrm{X})$ & $0.5(1 \mathrm{X})$ & $0.5(1 \mathrm{X})$ & $0.5(1 \mathrm{X})$ & $0.5(1 \mathrm{X})$ \\
\hline D. Lumber-7/20 & $0.5(1 \mathrm{X})$ & $0.5(1 \mathrm{X})$ & $0.5(1 \mathrm{X})$ & $0.5(1 \mathrm{X})$ & $0.5(1 \mathrm{X})$ & $0.5(1 \mathrm{X})$ \\
\hline Delta 4-7/20 & $0.5(1 \mathrm{X})$ & $0.5(1 \mathrm{X})$ & $0.5(1 \mathrm{X})$ & $0.5(1 \mathrm{X})$ & $0.5(1 \mathrm{X})$ & $0.5(1 \mathrm{X})$ \\
\hline Shoot-7/10 & 0.8 & 0.8 & 0.8 & $0.8(20 \mathrm{X})$ & 0.8 & 0.8 \\
& $(20 \mathrm{X})$ & $(20 \mathrm{X})$ & $(20 \mathrm{X})$ & & $(20 \mathrm{X})$ & $(20 \mathrm{X})$ \\
\hline Root-7/10 & 0.7 & 0.7 & 0.7 & $0.7(10 \mathrm{X})$ & 0.7 & 0.7 \\
& $(10 \mathrm{X})$ & $(10 \mathrm{X})$ & $(10 \mathrm{X})$ & & $(10 \mathrm{X})$ & $(10 \mathrm{X})$ \\
\hline Taq Polymerase & 0.2 & 0.2 & 0.2 & 0.2 & 0.2 & 0.2 \\
\hline
\end{tabular}

July 24, 1995 RAPD reactions (4 DNA/10 Primers)

\begin{tabular}{|c|c|c|c|c|}
\hline & Delta 1 & Delta 2 & D. Lumber & Shoot \\
\hline $\begin{array}{l}\text { Distilled } \\
\text { Water }\end{array}$ & $18 \mathrm{~mL} / 234 \mathrm{~mL}$ & $\begin{array}{ll}18 & \mathrm{~mL} / 234 \\
\mathrm{~mL} & \\
\end{array}$ & $18 \mathrm{~mL} / 234 \mathrm{~mL}$ & $\begin{array}{ll}18 & \mathrm{~mL} / 234 \\
\mathrm{~mL} & \\
\end{array}$ \\
\hline PCR Buffer & $\begin{array}{ll}2.5 & \mathrm{~mL} / 32.5 \\
\mathrm{~mL} & \\
\end{array}$ & $\begin{array}{ll}2.5 & \mathrm{~mL} / 32.5 \\
\mathrm{~mL} & \\
\end{array}$ & $\begin{array}{ll}2.5 & \mathrm{~mL} / 32.5 \\
\mathrm{~mL} & \\
\end{array}$ & $\begin{array}{ll}2.5 & \mathrm{~mL} / 32.5 \\
\mathrm{~mL} & \\
\end{array}$ \\
\hline Cytosine & $0.5 \mathrm{~mL} / 6.5 \mathrm{~mL}$ & $0.5 \mathrm{~mL} 6.5 \mathrm{~mL}$ & $0.5 \mathrm{~mL} / 6.5 \mathrm{~mL}$ & $0.5 \mathrm{~mL} / 6.5 \mathrm{~mL}$ \\
\hline Guanine & $0.5 \mathrm{~mL} / 6.5 \mathrm{~mL}$ & $0.5 \mathrm{~mL} / 6.5 \mathrm{~mL}$ & $0.5 \mathrm{~mL} / 6.5 \mathrm{~mL}$ & $0.5 \mathrm{~mL} / 6.5 \mathrm{~mL}$ \\
\hline Adenine & $0.5 \mathrm{~mL} / 6.5 \mathrm{~mL}$ & $0.5 \mathrm{~mL} / 6.5 \mathrm{~mL}$ & $0.5 \mathrm{~mL} / 6.5 \mathrm{~mL}$ & $0.5 \mathrm{~mL} / 6.5 \mathrm{~mL}$ \\
\hline Thymine & $0.5 \mathrm{~mL} / 6.5 \mathrm{~mL}$ & $0.5 \mathrm{~mL} / 6.5 \mathrm{~mL}$ & $0.5 \mathrm{~mL} / 6.5 \mathrm{~mL}$ & $0.5 \mathrm{~mL} / 6.5 \mathrm{~mL}$ \\
\hline DNA & $\begin{array}{ll}1.0 & \mathrm{~mL} / 15.0 \\
\mathrm{~mL} & \end{array}$ & $0.5 \mathrm{~mL} / 7.5 \mathrm{~mL}$ & $0.5 \mathrm{~mL} / 7.5 \mathrm{~mL}$ & $\begin{array}{ll}0.8 & \mathrm{~mL} / 12.0 \\
\mathrm{~mL} & \\
\end{array}$ \\
\hline Primer & $1.0 \mathrm{ml}$ & $1.0 \mathrm{~mL}$ & $1.0 \mathrm{ml}$ & $1.0 \mathrm{~mL}$ \\
\hline $\begin{array}{l}\text { Taq } \\
\text { Polymerase }\end{array}$ & $0.2 \mathrm{~mL}$ & $0.2 \mathrm{~mL}$ & $0.2 \mathrm{~mL}$ & $0.2 \mathrm{~mL}$ \\
\hline
\end{tabular}


July 26, 1995 RAPD reactions (5 DNA/8 Primers)

\begin{tabular}{|c|c|c|c|c|c|}
\hline & Delta 1 & Delta 2 & D. Lumb. & NZ (A) & NZ (B) \\
\hline Dist. $\mathrm{H}_{2} \mathrm{O}$ & $\begin{array}{l}18 \mathrm{~mL} / 216 \\
\mathrm{~mL}\end{array}$ & $\begin{array}{l}18 \mathrm{~mL} / 216 \\
\mathrm{~mL}\end{array}$ & $\begin{array}{l}18 \mathrm{~mL} / 216 \\
\mathrm{~mL}\end{array}$ & $\begin{array}{l}18 \mathrm{~mL} / 216 \\
\mathrm{~mL}\end{array}$ & $\begin{array}{l}18 \mathrm{~mL} / 216 \\
\mathrm{~mL}\end{array}$ \\
\hline PCR Buffer & $\begin{array}{l}2.5 \mathrm{~mL} / 30 \\
\mathrm{~mL}\end{array}$ & $\begin{array}{ll}2.5 & \mathrm{~mL} / 30 \\
\mathrm{~mL} & \end{array}$ & $\begin{array}{l}2.5 \mathrm{~mL} / 30 \\
\mathrm{~mL}\end{array}$ & $\begin{array}{l}2.5 \mathrm{~mL} / 30 \\
\mathrm{~mL}\end{array}$ & $\begin{array}{l}2.5 \mathrm{~mL} / 30 \\
\mathrm{~mL}\end{array}$ \\
\hline Adenine & $\begin{array}{ll}0.5 & \mathrm{~mL} / 6 \\
\mathrm{~mL} & \end{array}$ & $\begin{array}{ll}0.5 & \mathrm{~mL} / 6 \\
\mathrm{~mL} & \end{array}$ & $\begin{array}{l}0.5 \mathrm{~mL} / 6 \\
\mathrm{~mL}\end{array}$ & $\begin{array}{ll}0.5 & \mathrm{~mL} / 6 \\
\mathrm{~mL} & \end{array}$ & $\begin{array}{ll}0.5 & \mathrm{~mL} / 6 \\
\mathrm{~mL} & \end{array}$ \\
\hline Cytosine & $\begin{array}{ll}0.5 & \mathrm{~mL} / 6 \\
\mathrm{~mL} & \end{array}$ & $\begin{array}{ll}0.5 & \mathrm{~mL} / 6 \\
\mathrm{~mL} & \end{array}$ & $\begin{array}{ll}0.5 & \mathrm{~mL} / 6 \\
\mathrm{~mL}\end{array}$ & $\begin{array}{ll}0.5 & \mathrm{~mL} / 6 \\
\mathrm{~mL} & \end{array}$ & $\begin{array}{ll}0.5 & \mathrm{~mL} / 6 \\
\mathrm{~mL}\end{array}$ \\
\hline Guanine & $\begin{array}{l}0.5 \mathrm{~mL} / 6 \\
\mathrm{~mL}\end{array}$ & $\begin{array}{ll}0.5 & \mathrm{~mL} / 6 \\
\mathrm{~mL} & \\
\end{array}$ & $\begin{array}{ll}0.5 & \mathrm{~mL} / 6 \\
\mathrm{~mL} & \\
\end{array}$ & $\begin{array}{ll}0.5 & \mathrm{~mL} / 6 \\
\mathrm{~mL} & \\
\end{array}$ & $\begin{array}{ll}0.5 & \mathrm{~mL} / 6 \\
\mathrm{~mL} & \\
\end{array}$ \\
\hline Thymine & $\begin{array}{ll}0.5 & \mathrm{~mL} / 6 \\
\mathrm{~mL} & \\
\end{array}$ & $\begin{array}{ll}0.5 & \mathrm{~mL} / 6 \\
\mathrm{~mL} & \\
\end{array}$ & $\begin{array}{ll}0.5 & \mathrm{~mL} / 6 \\
\mathrm{~mL} & \\
\end{array}$ & $\begin{array}{ll}0.5 & \mathrm{~mL} / 6 \\
\mathrm{~mL} & \\
\end{array}$ & $\begin{array}{ll}0.5 & \mathrm{~mL} / 6 \\
\mathrm{~mL} & \\
\end{array}$ \\
\hline DNA & $\begin{array}{ll}1 & \mathrm{~mL} / 12 \\
\mathrm{~mL} & \end{array}$ & $\begin{array}{ll}0.5 & \mathrm{~mL} / 6 \\
\mathrm{~mL} & \\
\end{array}$ & $\begin{array}{ll}1 & \mathrm{~mL} / 12 \\
\mathrm{~mL}\end{array}$ & $\begin{array}{ll}0.4 & \mathrm{~mL} / 4 \\
\mathrm{~mL} & \\
\end{array}$ & $\begin{array}{l}0.3 \mathrm{~mL} / 3.6 \\
\mathrm{~mL}\end{array}$ \\
\hline & $1 \mathrm{~mL}$ & $1 \mathrm{~mL}$ & $1 \mathrm{~mL}$ & $1 \mathrm{~mL}$ & $1 \mathrm{~mL}$ \\
\hline & $0.2 \mathrm{~mL}$ & $0.2 \mathrm{~mL}$ & $0.2 \mathrm{~mL}$ & $0.2 \mathrm{~mL}$ & $0.2 \mathrm{~mL}$ \\
\hline
\end{tabular}

July 27, 1995 RAPD reactions (5 DNA/3 Primers)

\begin{tabular}{|l|l|l|l|}
\hline & C5 & C11 & R2 \\
\hline Distilled Water & $18 \mathrm{~mL} / 126 \mathrm{~mL}$ & $18 \mathrm{~mL} / 126 \mathrm{~mL}$ & $18 \mathrm{~mL} / 126 \mathrm{~mL}$ \\
\hline PCR Buffer & $2.5 \mathrm{~mL} / 17.5 \mathrm{~mL}$ & $2.5 \mathrm{~mL} / 17.5 \mathrm{~mL}$ & $2.5 \mathrm{~mL} / 17.5 \mathrm{~mL}$ \\
\hline Adenine & $0.5 \mathrm{~mL} / 3.5 \mathrm{~mL}$ & $0.5 \mathrm{~mL} / 3.5 \mathrm{~mL}$ & $0.5 \mathrm{~mL} / 3.5 \mathrm{~mL}$ \\
\hline Cytosine & $0.5 \mathrm{~mL} / 3.5 \mathrm{~mL}$ & $0.5 \mathrm{~mL} / 3.5 \mathrm{~mL}$ & $0.5 \mathrm{~mL} / 3.5 \mathrm{~mL}$ \\
\hline Thymine & $0.5 \mathrm{~mL} / 3.5 \mathrm{~mL}$ & $0.5 \mathrm{~mL} / 3.5 \mathrm{~mL}$ & $0.5 \mathrm{~mL} 3.5 \mathrm{~mL}$ \\
\hline Guanine & $0.5 \mathrm{~mL} / 3.5 \mathrm{~mL}$ & $0.5 \mathrm{~mL} / 3.5 \mathrm{~mL}$ & $0.5 \mathrm{~mL} / 3.5 \mathrm{~mL}$ \\
\hline Primer & $1 \mathrm{~mL} / 7 \mathrm{~mL}$ & $1 \mathrm{~mL} / 7 \mathrm{~mL}$ & $1 \mathrm{~mL} / 7 \mathrm{~mL}$ \\
\hline DNA & & & \\
\hline Delta 1 & $1.0 \mathrm{~mL}$ & $1.0 \mathrm{~mL}$ & $1.0 \mathrm{~mL}$ \\
\hline Delta 2 & $0.5 \mathrm{~mL}$ & $0.5 \mathrm{~mL}$ & $0.5 \mathrm{~mL}$ \\
\hline$D$. Lumber & $1.0 \mathrm{~mL}$ & $1.0 \mathrm{~mL}$ & $1.0 \mathrm{~mL}$ \\
\hline NZ(A) & $0.4 \mathrm{~mL}$ & $0.4 \mathrm{~mL}$ & $0.4 \mathrm{~mL}$ \\
\hline NZ(B) & $0.3 \mathrm{~mL}$ & $0.3 \mathrm{~mL}$ & $0.3 \mathrm{~mL}$ \\
\hline Taq-Polymerase & $0.2 \mathrm{~mL}$ & $0.2 \mathrm{~mL}$ & $0.2 \mathrm{~mL}$ \\
\hline
\end{tabular}


Appendix C: Lane Assignments for RAPD Gel Analysis

RAPD Reactions: July 21, 1995

\begin{tabular}{|c|c|c|c|c|c|}
\hline Lane & PRIMER & DNA & LANE & PRIMER & DNA \\
\hline 1 & $\mathrm{C} 01$ & Delta 1 & 23 & G04 & Delta 1 \\
\hline 2 & $\mathrm{C} 01$ & Delta 2 & 24 & G04 & Delta 2 \\
\hline$\overline{3}$ & $\mathrm{C01}$ & Delta 3 & 25 & G04 & Delta 3 \\
\hline 4 & $\mathrm{CO1}$ & $\begin{array}{l}\text { Davis } \\
\text { Lumber }\end{array}$ & 26 & G04 & $\begin{array}{l}\text { Davis } \\
\text { Lumber }\end{array}$ \\
\hline 5 & $\mathrm{C} 01$ & Delta 4 & 27 & G04 & Delta 4 \\
\hline 6 & $\mathrm{C} 01$ & Shoot & 28 & G04 & Shoot \\
\hline 7 & $\mathrm{C} 01$ & Root & 29 & G04 & Root \\
\hline 8 & $\mathrm{CO2}$ & Delta 1 & 30 & $\mathrm{R} 01$ & Delta 1 \\
\hline 9 & $\mathrm{CO2}$ & Delta 2 & 31 & R01 & Delta 2 \\
\hline 10 & $\mathrm{CO2}$ & Delta 3 & 32 & R01 & Delta 3 \\
\hline 11 & $\mathrm{CO2}$ & $\begin{array}{l}\text { Davis } \\
\text { Lumber }\end{array}$ & 33 & R01 & $\begin{array}{l}\text { Davis } \\
\text { Lumber }\end{array}$ \\
\hline 12 & $\mathrm{C02}$ & Delta 4 & 34 & $\mathrm{R} 01$ & Delta 4 \\
\hline 13 & $\mathrm{CO2}$ & Shoot & 35 & R01 & Shoot \\
\hline 14 & $\mathrm{C02}$ & Root & 36 & R01 & Root \\
\hline 15 & $\begin{array}{l}\text { STANDA } \\
\text { RD } \\
\end{array}$ & $\begin{array}{l}\text { STANDA } \\
\text { RD } \\
\end{array}$ & 37 & $\begin{array}{l}\text { STANDA } \\
\text { RD }\end{array}$ & $\begin{array}{l}\text { STANDA } \\
\text { RD }\end{array}$ \\
\hline 16 & G02 & Delta 1 & 38 & R02 & Delta 1 \\
\hline 17 & G02 & Delta 2 & 39 & $\mathrm{R} 02$ & Delta 2 \\
\hline 18 & G02 & Delta 3 & 40 & R02 & Delta 3 \\
\hline 19 & G02 & $\begin{array}{l}\text { Davis } \\
\text { Lumber }\end{array}$ & 41 & R02 & $\begin{array}{l}\text { Davis } \\
\text { Lumber }\end{array}$ \\
\hline 20 & G02 & Delta 4 & 42 & R02 & Delta 4 \\
\hline 21 & $\mathrm{G} 02$ & Shoot & 43 & R02 & Shoot \\
\hline 22 & G02 & Root & 44 & $\overline{\mathrm{R} 02}$ & Root \\
\hline
\end{tabular}


RAPD Reactions: July 24, 1995

\begin{tabular}{|l|l|l|l|l|l|}
\hline Lane & PRIMER & DNA & LANE & PRIMER & DNA \\
\hline 1 & C04 & Delta 1 & 23 & G11 & Delta 1 \\
\hline 2 & C04 & Delta 2 & 24 & G11 & Delta 2 \\
\hline 3 & C04 & $\begin{array}{l}\text { Davis } \\
\text { Lumber }\end{array}$ & 25 & G11 & $\begin{array}{l}\text { Davis } \\
\text { Lumber }\end{array}$ \\
\hline 4 & C04 & Shoots & 26 & G11 & Shoots \\
\hline 5 & C05 & Delta 1 & 27 & G17 & Delta 1 \\
\hline 6 & C05 & Delta 2 & 28 & G17 & Delta 2 \\
\hline 7 & C05 & $\begin{array}{l}\text { Davis } \\
\text { Lumber }\end{array}$ & 29 & G17 & $\begin{array}{l}\text { Davis } \\
\text { Lumber }\end{array}$ \\
\hline 8 & C05 & Shoots & 30 & G17 & Shoots \\
\hline 9 & C06 & Delta 1 & 31 & R06 & Delta 1 \\
\hline 10 & C06 & Delta 2 & 32 & R06 & Delta 2 \\
\hline 11 & C06 & $\begin{array}{l}\text { Davis } \\
\text { Lumber }\end{array}$ & 33 & R06 & $\begin{array}{l}\text { Davis } \\
\text { Lumber }\end{array}$ \\
\hline 12 & C06 & Shoots & 34 & R06 & Shoots \\
\hline 13 & STANDA & $\begin{array}{l}\text { STANDA } \\
\text { RD }\end{array}$ & 35 & $\begin{array}{l}\text { STANDA } \\
\text { RD }\end{array}$ & $\begin{array}{l}\text { STANDA } \\
\text { RD }\end{array}$ \\
\hline 14 & C11 & Delta 1 & 36 & R11 & Delta 1 \\
\hline 15 & C11 & Delta 2 & 37 & R11 & Delta 2 \\
\hline 16 & C11 & $\begin{array}{l}\text { Davis } \\
\text { Lumber }\end{array}$ & 38 & R11 & $\begin{array}{l}\text { Davis } \\
\text { Lumber }\end{array}$ \\
\hline 17 & C11 & Shoots & 39 & R11 & Shoots \\
\hline 18 & C15 & Delta 1 & 40 & T4 & Delta 1 \\
\hline 19 & C15 & Delta 2 & 41 & T4 & Delta 2 \\
\hline 20 & C15 & $\begin{array}{l}\text { Davis } \\
\text { Lumber }\end{array}$ & 42 & T4 & $\begin{array}{l}\text { Davis } \\
\text { Lumber }\end{array}$ \\
\hline 21 & C15 & Shoots & 43 & T4 & Shoots \\
\hline 22 & Hydrilla (M) & Doreen & 44 & Hydrilla (D) & Doreen \\
\hline
\end{tabular}


RAPD Reactions: July 26, 1995

\begin{tabular}{|l|l|l|l|l|l|}
\hline Lane & PRIMER & DNA & LANE & PRIMER & DNA \\
\hline 1 & C05 & Delta 1 & 23 & R1 & Delta 1 \\
\hline 2 & C05 & Delta 2 & 24 & R1 & Delta 2 \\
\hline 3 & C05 & $\begin{array}{l}\text { Davis } \\
\text { Lumber }\end{array}$ & 25 & R1 & $\begin{array}{l}\text { Davis } \\
\text { Lumber }\end{array}$ \\
\hline 4 & C05 & NZ(A) & 26 & R1 & NZ (A) \\
\hline 5 & C05 & NZ(B) & 27 & R1 & NZ(B) \\
\hline 6 & C11 & Delta 1 & 28 & R2 & Delta 1 \\
\hline 7 & C11 & Delta 2 & 29 & R2 & Delta 2 \\
\hline 8 & C11 & Davis \\
Lumber & 30 & R2 & $\begin{array}{l}\text { Davis } \\
\text { Lumber }\end{array}$ \\
\hline 9 & C11 & NZ(A) & 31 & R2 & NZ(A) \\
\hline 10 & C11 & NZ(B) & 32 & R2 & NZ(B) \\
\hline 11 & STANDA & $\begin{array}{l}\text { STANDA } \\
\text { RD }\end{array}$ & 33 & $\begin{array}{l}\text { STANDA } \\
\text { RD }\end{array}$ & $\begin{array}{l}\text { STANDA } \\
\text { RD }\end{array}$ \\
\hline 12 & C15 & Delta 1 & 34 & R11 & Delta 1 \\
\hline 13 & C15 & Delta 2 & 35 & R11 & Delta 2 \\
\hline 14 & C15 & $\begin{array}{l}\text { Davis } \\
\text { Lumber }\end{array}$ & 36 & R11 & $\begin{array}{l}\text { Davis } \\
\text { Lumber }\end{array}$ \\
\hline 15 & C15 & NZ(A) & 37 & R11 & NZ(A) \\
\hline 16 & C15 & NZ(B) & 38 & R11 & NZ (B) \\
\hline 17 & G17 & Delta 1 & 39 & T4 & Delta 1 \\
\hline 18 & G17 & Delta 2 & 40 & T4 & Delta 2 \\
\hline 19 & G17 & Davis \\
Lumber & 41 & T4 & $\begin{array}{l}\text { Davis } \\
\text { Lumber }\end{array}$ \\
\hline 20 & G17 & NZ(A) & 42 & T4 & NZ (A) \\
\hline 21 & G17 & NZ(B) & 43 & T4 & NZ (B) \\
\hline 22 & Empty & Empty & 44 & Empty & Empty \\
\hline
\end{tabular}


RAPD reactions: July 27, 1995

\begin{tabular}{|l|l|l|}
\hline Lane & Primer & DNA \\
\hline 1 & C5 & Delta 1 \\
\hline 2 & C5 & Delta 2 \\
\hline 3 & C5 & Davis Lumber \\
\hline 4 & C5 & NZ(A) \\
\hline 5 & C5 & NZ(B) \\
\hline 6 & C11 & Delta 1 \\
\hline 7 & C11 & Delta 2 \\
\hline 8 & C11 & Davis Lumber \\
\hline 9 & C11 & NZ(A) \\
\hline 10 & C11 & NZ(B) \\
\hline 11 & STANDARD & STANDARD \\
\hline 12 & R2 & Delta 1 \\
\hline 13 & R2 & Delta 2 \\
\hline 14 & R2 & Davis Lumber \\
\hline 15 & R2 & NZ(A) \\
\hline 16 & R2 & NZ (B) \\
\hline
\end{tabular}




\section{References}

1. Charlieu, J.P. 1994. PCR as a technique used daily in molecular biology. In Griffin, H.G. and Griffin, A.M. (ed.) PCR Technology Current Innovations, Chapter 1, 1-4 CRC Press, Inc., Boca Raton, Florida

2. Demeka, T. and Adams, R.P. 1994. The use of PCR-RAPD analysis in plant taxonomy and evolution. In Griffin, H.G. and Griffin, A.M. (ed.) PCR Technology Current Innovations. Chapter 21, 179-191. CRC Press, Inc., Boca Raton, Florida

3. Maniatis. 1984. Molecular Cloning: A Lab Manual (2nd ed.) Cold Spring Harbor, Lab Press

4. McHenry, W.B. 1977. Aquatic weeds and their control. California Agriculture.

5. Mullis, Kary B. 1990. The Unusual Origin of the Polymerase Chain Reaction. Scientific American.

6. Rafalski, Antoni, Scott Tingey, and John G.K. Williams. Random amplified Polymorphic DNA (RAPD) markers. Plant Molecular Biology Manual. Chapter 8, 1-9, 1993. Kluwer Academic Publishers.

7. Senft, Dennis. 1995. News from the Aquatic Weed Front. Agricultural Research. Agricultural Research Service/USDA.

8. Yu, K. and Pauls, K.P. 1994. Optimization of DNA extraction and PCR procedures for random amplified DNA (RAPD) analysis in plants. In Griffin, H.6. and Griffin, A.M. (ed.) PCR Technology Current Innovations. Chapter 22, 193200. CRC Press, Inc., Boca Raton, Florida 


\title{
The Effect of Marination on the Formation of Heterocyclic Aromatic Amines in Cooked Chicken Meat
}

\author{
Rita K. Ng \\ Teacher: J. Kirk Brown \\ Tracy High School \\ Tracy, CA
}

\begin{abstract}
Observed differences in cancer rates worldwide are linked to variations in human diets and the consumption of dietary chemicals. By conducting research in this area, strategies may be discovered for the prevention of cancer in humans. When food derived from muscle is heated, potent cancer-causing mutagens called heterocyclic aromatic amines (HAAs) are naturally formed. To determine the effect of marination on the formation of HAAs in chicken meat, whole chicken breasts were marinated using three types of marinades (Indian Tandoori marinade, American Southern marinade, Japanese Teriyaki marinade) and single ingredients (yogurt, brown sugar, soy sauce). The HAAs were extracted from the meats according to the Gross method (Gross, 1990) and the mutagenicity determined using the Ames/Salmonella bioassay (Ames et al., 1975) with Salmonella typhimurium strain TA98. The results of the research confirmed that varying preparation methods substantially affected the amount of HAAs formed. Marination resulted in mutagenic activity of up to 9-fold higher for the chicken, compared to an unmarinated control. The data yielded a preliminary indication as to the cause of varying cancer rates as exposure to cancer-causing compounds deviates in different cultures. The American marinade was found to be the most potent followed by the Indian and Japanese marinade, respectively. Marination time did not consistently alter the mutagenesis of the samples, while sugar seemed to significantly decrease mutagenic activity. Cancer causation remains a primary concern in today's world, particularly as it relates to low-level carcinogen exposure over extended periods of time. Although the HAAs are present in only very small amounts in foods consumed on a daily basis, these amines are the most mutagenic compounds ever found and are known to produce tumors in rodents when given in concentrated doses. An important implication of this research is the identification of strategies for managing the potential risks associated with dietary exposures to HAAs.
\end{abstract}

\section{Introduction}

Public concem regarding the potential mechanisms that induce the formation of cancerous cells is warranted. Nearly one-third of all Americans will contract cancer during their lifetimes and approximately one quarter will die of some form of this disease (Hrudey, 1995). A 1964 World Health Organization report concluded that three-quarters of all human cancers are caused by extrinsic factors other than genetic predisposition.

Mutagens, damaging agents that structurally change the molecular units that make up the genes, are believed to be the initiating agents of the cancer 
process. Since the 1970s, extensive research has been conducted to identify possible mutagens in the environment. X-rays, ultraviolet lights, and other chemicals have been discovered to cause mutations in the DNA of organisms. The observed differences in cancer rates worldwide have been linked to variations in human diets and the consumption of dietary chemicals (Doll and Peto, 1981). This presents the important task of assessing and quantifying cancer-causing mutagens, or carcinogens, naturally found in certain food products. Furthermore, since mutagens are also known to be formed during the cooking process, strategies may be discovered for the prevention of cancer in humans by understanding which methods of food preparation are most at risk to yield carcinogens.

In 1977, the presence of mutagenic substances in broiled fish and beef was first confirmed when extracted chemicals induced mutations in colonies of bacteria (Sugimura et al., 1977). Cooking conditions such as temperature and time were also found to significantly affect the formation of mutagens in food (Commoner et al., 1978). As the duration and intensity of cooking time was increased, the level of mutagenic activity similarly increased (Sflomas et al., 1989). Since the discovery of the existence of these carcinogens in heated protein-rich foods, known as heterocyclic aromatic amines (HAAs), a considerable amount of scientific interest has been devoted to their study.

Muscle meats contain creatine and creatinine, precursors that react with free amino acids and sugars to form heterocyclic amines when cooked at high temperatures (Knize et al., 1994; Jagerstad et al., 1991). Removing the known precursors of heterocyclic amines from beef patties, by microwave pretreatment before frying, was shown by Felton et al. (1994) to reduce the formation of mutagenic activity by $95 \%$. HAA's are not mutagenic while initially in the cooked foods. They only become highly carcinogenic after being metabolized by enzymes when ingested. As the body attempts to excrete the ingested lipophilic toxins, the intracellular enzymes act on the HAA's to convert them into chemically more polar forms. In the process of bioactivation, certain intermediate food-mutagen molecules are formed that covalently bind to specific atoms in the DNA. This causes mutations as structural changes occur in the molecular units that make up the genes of the DNA. Consequently, the genes of daughter cells in subsequent generations are unable to function properly as they are replicated from the mutated strand. In some cases, the mutations occur in genes controlling cell proliferation and replication, leading to cancerous tumors.

The purpose of this study is to determine if food preparation methods in different cultures influences the formation of HAAs. This will be accomplished by quantifying the mutagens formed in grilled chicken breasts saturated with three different types of marinades (Indian Tandoori marinade, American Southern marinade, Japanese Teriyaki marinade). Furthermore, the time allotted for marination in each of the samples will be examined to discover if there is a correlation between marination time and the formation of HAAs. Finally, the principal ingredient in each marinade will be isolated (yogurt, sugar, soysauce 
respectively) and tested individually to note its effect on the mutagenicity of the meat sample.

\section{The Ames/Salmonella Assay}

The Ames/Salmonella Assay (Ames et al., 1975), a test that uses bacteria as an indicator of DNA damage, will be employed to assess the mutagenic potency of each sample. Although this test does not directly demonstrate cancer risk, some $80-90 \%$ of mutagenic substances are also known to be carcinogenic in rodents (McCann et al., 1975). The Ames method is based on inducing growth in genetically altered strains of the bacterium Salmonella typhimurium, which are altered to only grow in the presence of the amino acid histidine. However, when the chemical mutagen that is being studied is given to the bacteria, some of the altered Salmonella undergo mutations. The bacterial DNA base changes are reverted in such a way that the protein coded from the DNA sequence is now functional. These bacteria are essentially mutated back to their wild unaltered state, enabling them grow visible "revertant" colonies even in the absence of histidine.

The Ames test yields a measure of mutagenic activity as the number of revertant (equal to the number of revertant colonies) per gram of sample. Altered Salmonella bacteria are placed in a petri dish containing a nutrient agar lacking histidine. A few bacteria will spontaneously revert in the absence of mutagens and serve as a baseline against which to check the validity of the procedure. In a separate but essentially identical histidine-deficient petri dish, another batch of altered Salmonella bacteria are given a mutagen in addition to mammalian enzymes that are required for the bioactivation of the mutagens. This is effective in simulating the role of human metabolism in the test. After incubation, the number of visible revertant bacteria colonies are counted and used to calculate the potency of the mutagen in terms of grams of original sample extracted.

\section{Hypotheses}

I. All three types of marinaded chicken breasts (American Southern marinade, Japanese Teriyaki marinade, and Indian Tandoori marinade) will test positive for mutagens.

II. Given that glucose is a supposed precursor for the formation of heterocyclic amines (Jagerstad et al., 1991), the high sugar content in the American Southern marinade will cause it to have the highest rate of mutagenic activity.

III. Prolonged imbibition of the marinade into the chicken breasts will yield higher levels of mutagenic activity.

IV. The single-ingredients will have similar mutagenic effects on the chicken samples as their respective marinades.

\section{Materials and Methods}

Seven samples of chicken breast meat were prepared using three different types of marinade: Indian Tandoori Marinade, American Southern Marinade, and Japanese Teriyaki Marinade (Appendix A). Samples were soaked for 4 
hour and 24-hour increments in each respective marinade, as well as a control with no marination. The chicken samples were then grilled at a surface temperature of $600 \mathrm{C}$ until an internal temperature of $100 \mathrm{C}$ was recorded.

A second set of experiments was conducted using single ingredient marinades, with a more extensive study on the effect of marinating time. The principle ingredient of each marinade was isolated: yogurt (Indian Tandoori marinade), brown sugar (American Sugar marinade), and soy sauce (Japanese Teriyaki marinade). In addition to a control sample with no marination, samples were soaked for $4,8,12,16,20$, and 24 hour increments in each respective ingredient, then grilled in a similar fashion.

The heterocyclic amines of the cooked samples were then extracted according to the Gross method (Gross, 1990). Each sample was ground up in a blender to obtain a uniform sample. 15 grams of the sample were then weighed out and homogenized with 45 grams of $1 \mathrm{M} \mathrm{NaOH}$ in a polytron (Omni International, Gainsville, VA). Extube Hydromatrix diatomaceous earth was mixed in to provide a matrix to hold the liquified sample before the mixtures were transferred to Chem Elut extraction columns (100 ml size; Varian Sample Preparation Products, Harbor City, CA) coupled to PRS columns. $200 \mathrm{ml}$ of solvent ( $5 \%$ toluene in methylene chloride) was poured through the columns. The solvent essentially collected the mutagenic substances as it flowed through the liquified food sample suspended in the diatomaceous earth. The heterocyclic amines in the solvent were then absorbed into the PRS column while the remaining solvent dripped out into a waste container. The PRS column was then vacuumed for 10 minutes to remove any traces of solvent.

The PRS column was eluted with $2 \mathrm{ml} 9: 1$ methanol (100\%) to ammonium hydroxide (58\%) in order to wash the collected substances into a glass vial. The solvents were then evaporated under a stream of nitrogen, leaving only the potentially mutagenic compounds (heterocyclic aromatic amines) contained in the dry vial.

The mutagenic activity of the sample extracts was determined using Ames/Salmonella bioassay. $100 \mathrm{ul}$ of the genetically mutated Salmonella typhimurium strain TA98 bacteria were added to each test tube. The extracted compounds in the vials were diluted with dimethylsulfoxide solvent (DMSO) and added to the test tubes in varying doses $(5,10,25,50$, and $100 \mathrm{ul})$. Two tubes of each dose were produced to ensure the accuracy of results. $0.5 \mathrm{ml}$ of $\mathrm{S} 9$ mixture (containing mammalian enzymes, cofactor: NADP and Glucose-6phosphate, and buffer: $\mathrm{MgCl}_{2}$ and $\mathrm{KC}_{1} \mathrm{PO}_{4}$ ) were also added to each of the tubes. The enzymes were supplied from liver cell extracts of rats given Aroclor 1254 to increase levels of metabolizing enzymes for the bioactivation of the potential mutagens. After vortexing the contents of the tubes, the solutions were poured onto sterile petri plates with agar. A negative control was prepared by adding 100 ul DMSO to two plates. Similarly, a known carcinogen 2AA was used to establish a positive control. The prepared plates were then placed into a 37 incubator and turned upside down to keep the condensation from dripping on to the agar surface. After allotting 72 hours for growth, the number of 
revertant colonies were counted to quantify the mutagenic activity of each tested compound.

Mutagenic activity dose-response curves were calculated using the method of Moore and Felton (1983). The linear portion of the curve was used to calculate the number of revertant per gram of original sample extracted.

\section{Limitations}

Several limitations arose in the process of this study. Since it was known that cooking conditions (particularly cooking time and temperature) significantly influenced the formation of heterocyclic amines, every attempt was made to cook the marinaded samples of chicken meat in a uniform fashion. All the samples were grilled at a constant surface temperature of $600^{\circ} \mathrm{C}$ and removed from the heat when an internal temperature of $100^{\circ} \mathrm{C}$ was attained. Unfortunately, since all the pieces of marinaded meat were of varying dimensions and weights prior to cooking, it was virtually impossible to regulate the cooking time while still maintaining the constant temperature conditions. Consequently, it was difficult to solely assess the effect of the marinades on the meat samples without taking into account other extrinsic cooking factors. An attempt was made to rectify this problem in the second phase of the experiment involving the single-ingredient marinades. By cutting the meat samples with a circular cork-borer prior to marination, the samples were more similar in weight and dimension. This substantially reduced the wide variation in cooking time experienced in the first part of the experiment, although slight deviances still occurred.

A second limitation involved the testing of the single ingredient marinades. Although the principle ingredient of each marinade was used, there was no way to know if the isolated ingredient was in fact the mutagenic agent of the mixture. The marinades had many different ingredients, with each being a potential mutagen. To truly assess the mutagenic activity of the complete marinade, each individual ingredient of the marinade would have had to be isolated and evaluated individually. However, due to the costs of the tests, this was not a plausible option.

Furthermore, although the Ames test is an exquisitely sensitive biological method for measuring the mutagenic potency of chemical substances, its application was also limited. The TA98 strain is only one of the many strains of altered bacteria Salmonella typhimurium. Although TA98 is highly effective and responds to a wide range of different mutagens, it is possible that some of the extracted mutagens from the samples did not respond to this particular strain. Further experiments should be conducted utilizing other strains that would potentially yield more revertant colonies.

\section{Results}

In the first part of the experiment, marinating the whole chicken breasts resulted in Ames/Salmonella mutagenic activity up to 3-fold higher for meat marinated 4 hours and up to 9-fold higher for meat marinated 24 hours, compared to an unmarinated control. Furthermore, the results show that each type of marinade 
formed a distinct number of revertant colonies per gram of original food extract $(\mathrm{rev} / \mathrm{g})$. The Southern marinade exhibited the highest level of mutagenic activity of the three types of marinades. All data seemed to be relatively accurate except for the 4-hour Tandoori sample, which yielded $80.72 \mathrm{rev} / \mathrm{g}$. The accuracy of this data should be questioned as it was much lower than even the control sample (245.03 rev/g). It is unlikely that the Tandoori marinade acted to reduce the formation of heterocyclic amines given that the 24-hour Tandoori sample yielded a high count of $1299.38 \mathrm{rev} / \mathrm{g}$. Scientific error is the most probable explanation for this discrepancy. Consequently, the sample was not taken into consideration during later analysis and interpretation of the yielded data.

The second part of the experiment, involving the principle ingredients of each of the marinades, yielded much different data. Unlike the complete marinades where a clear correlation was seen between increased marination time and increased mutagenic activity, the time of marination did not yield conclusive results. No gradual increase or decrease was consistently noted in the number of rev/g as the marination time was increased. However, all samples seemed to exhibit increased activity at the four hour increment and then mutagenesis dramatically dropped at the eight hour increment. Furthermore, another consistent result was the effect of the sugar in lowering the mutagenic activity. The sugar had the lowest mutagenic activity of both the yogurt and the soy sauce.

\section{Discussion}

Hypothesis I. All three types of marinaded chicken breasts (American Southern marinade, JapaneseTeriyaki marinade, and Indian Tandoori marinade) will test positive for mutagens.

The first hypothesis was confirmed. All marinated meat samples, with the exception of the questionable results of the 4-hour Tandoori sample, were mutagenic. The Indian Tandoori marinade, the American Southern marinade, and the Japanese Teriyaki marinade all exhibited higher levels of mutagenic activity (as quantified in the number of rev/g) than the unmarinated control sample $(245 \mathrm{rev} / \mathrm{g})$. This shows that marination played a role in the formation of more heterocyclic amines, supplementary to those that were naturally formed in the process of cooking the chicken.

Hypothesis II. Given that glucose is a precursor for the formation of heterocyclic amines, the American Southern marinade will have the highest rate of mutagenic activity.

This hypothesis was only partially confirmed. The American southern marinade did have the highest rate of mutagenic activity (2235 rev/g) in the 24-hour grilled chicken samples, with approximately double the amount of rev/g than the Indian Tandoori sample (1299 rev/g) and triple the effect of the Japanese Teriyaki sample (772 rev/g). However, although glucose is supposedly a precursor for the formation of heterocyclic amines, it is uncertain whether the sugar in the marinade was the principle cause of the increased activity. Subsequent experiments (that will be discussed in the analysis of Hypothesis IV) showed the effect of sugar on the chicken in actually decreasing the mutagenesis of the TA98 strain of Salmonella typhimurium. 
Hypothesis III. Prolonged imbibition of the marinade into the chicken breasts will yield higher levels of mutagenic activity.

This hypothesis was not conclusively proven. Preliminary indication was made in the complete marinade samples (Indian Tandoori marinade, American Southern marinade, Japanese Teriyaki marinade) that supported this assumption. As evidenced in the data, the samples allowed to soak in the marinade for 24 hours yielded much higher levels of mutagenic activity (as quantified in rev/g) than the corresponding 4 hour samples (Figure 2).

However, the second set of data seemed to disprove this hypothesis. No clear correlation was found between marination time and mutagenesis in the singleingredient experiments. The highest number of rev/g for the brown sugar, yogurt, and soy sauce chicken samples were all attained after being marinated for only four hours. If the hypothesis had been affirmed, this effect would have been noted after the chicken had been marinated for the longest duration of time (24 hours). Furthermore, a sharp drop in the formation of mutagens was noted at the 8-hour increment. This seems to indicate that there is not a linear relationship between marination time and the formation of heterocyclic amines.

Hypothesis IV. The single-ingredients will have similar mutagenic effects on the chicken samples as their respective marinades.

This hypothesis was disproved. The principle ingredient of the marinades is not necessarily the mutagenic agent. This was clearly evident in the American Sugar marinade and its principal ingredient, brown sugar. While the complete marinade produced the greatest number of revertant per gram of original food extracted of the three types of marinades tested, the isolated sugar recorded the least amount of mutagenic activity among the tested yogurt and soy sauce. In fact, the sugar seemed to decrease the mutagenicity of the TA98 strain of Salmonella bacteria.

This was a surprising result as glucose was previously found to be a precursor for the formation of heterocyclic amines (Jagerstad et al., 1991). Consequently, it was expected that the sugar in the marinade was the cause of the high mutagenic potency. However, when isolated, the brown sugar did not repeat its effects. A possible explanation for this seemingly contradictory finding is in the concentration of sugar used to marinate the chicken in the single-ingredient experiments.

Of the three single ingredients chosen to be tested, the brown sugar was the only solid that needed to be made into a solution prior to marination of the chicken sample. Both the yogurt and soy sauce were already in a liquid state. 100 grams of brown sugar were dissolved in $50 \mathrm{ml}$ of water, making a $66 \%$ sugar-water solution. This was much more concentrated than the amount of sugar found in the original American Sugar marinade, which also contained other ingredients to further dilute its potency. This high concentration may have potentially caused the osmotic movement of water out of the sample, attributing to the diffusion of the water-soluble mutagen precursors (creatine, creatinine, amino acids, glucose) out of the chicken meat and into the sugar-water. Since 
the concentration of solutes in the sugar-water was higher than the concentration of solutes within the piece of chicken, it is reasonable that this may have occurred. With less mutagen precursors present within the meat prior to cooking, fewer heterocyclic amines would have been formed when heated.

This theory is supported by the study previously cited that was conducted by $\mathrm{J}$. Felton et al. (1994). By microwave pretreatment of beef patties prior to cooking, a clear liquid was released, which contained many of the precursors of mutagens. While $440 \mathrm{mg}$ of the precursor compound creatine was found in a $100 \mathrm{~g}$ sample of ground beef, microwaving the sample for 3 minutes was found to reduce the creatine content to $260 \mathrm{mg}$. When the resulting liquid was drained off before frying, the study showed that the mutagenic activity as measured by the Ames test was greatly reduced. After frying for 6 minutes at 250 , the microwaved meat only yielded $41 \mathrm{rev} / \mathrm{g}$ in comparison to $1400 \mathrm{rev} / \mathrm{g}$ for untreated meat. The same principle of decreased mutagenic activity by microwaving is applicable to this study. The diffusion of water and other watersoluble precursors out of the chicken as a result of a steep concentration gradient was similar to the released clear liquid that reduced the mutagenic activity in the beef patties. The longer that the samples were allowed to soak in the highly concentrated sugar-water, the less likely it would be that mutagenic compounds would form.

Consequently, it is possible that this hypothesis could have been affirmed. If the sugar water had been less concentrated and had not caused the osmotic movement of water and water-soluble mutagen precursors out of the meat, the isolated brown sugar may have exhibited similar mutagenic activity to the complete American Southern Marinade.

\section{Conclusions}

The results of the research confirmed that varying preparation methods, in terms of marinating meat, does affect the amount of heterocyclic aromatic amines formed. The American Southern marinade was found to be the most potent followed by the Indian Tandoori and Japanese Teriyaki marinade, respectively. The data obtained yields a preliminary indication as to the cause of varying cancer rates as exposure to cancer-causing compounds deviates in different cultures.

While the effect of marinating time on the formation of mutagens was not entirely conclusive, some consistent results were noted. In all the samples, mutagenic activity greatly increased during the first four hours of marination before sharply declining. Due to this trend, more extensive studies should be conducted to carefully note the effect of marinade on the meat during the first eight hours of marination. Perhaps the meat becomes saturated with the marinating solvent after only four hours, accounting for the high level of mutagenesis in the Salmonella typhimurium bacteria.

Finally, attempts to assess the role of sugar yielded interesting results. The gradual decline of rev/g in the chicken sample with prolonged exposure to the sugar water may possibly be explained by the osmotic movement of water and 
water-soluble mutagen precursors out of the meat. However, it also may not be entirely discounted that sugar plays a special role in reducing the formation of heterocyclic amines. Researchers in the Molecular Toxicology Group (Biomedical Sciences Division) at the Lawrence Livermore National Laboratory are currently investigating this phenomena as a result of the findings of this study.

Cancer causation remains a primary concern in today's world, particularly as it relates to low-level carcinogen exposure over extended periods of time. Although the HAAs are present in only very small amounts in foods consumed on a daily basis, these amines are the most mutagenic compounds ever found and are known to produce tumors in mice, rats, and monkeys (Bogen, 1994) when given in concentrated doses. It is estimated that 28,000 people living in the U.S. today will develop cancer during a 70 year life span resulting from dietary exposure to heterocyclic amines (Science \& Technology Review, 1995). Thus, an important implication of this research is the identification of possible strategies for managing the potential risks associated with dietary exposures to HAAs. A key objective in this regard would be to develop guidance on preparation methods that would decrease the formation of these compounds.

\section{Acknowledgments}

I wish to thank Mark G. Knize and J. Kirk Brown for their excellent supervision and guidance on this project. My gratitude is also given to Cynthia Salmon, Shilpi Mehta, and Julie Avila for their valuable technical assistance and discussion. My appreciation is further extended to the Biomedical Sciences Division at the Lawrence Livermore National Laboratory for allowing this study to take place. 


\section{References}

Ames, B., J. McCann, E. Yamasaki. "Methods for detecting carcinogens and mutagens with the Salmonella/mammalian-microsome mutagenicity test." Mutation Research, 1975.

Bogen, K.T. "Cancer Potencies of Heterocyclic Amines Found in Cooked Foods," Food Chemical Toxicology, 1994.

Commoner, B. et al. "Formation of mutagens in beef and beef extract during cooking." Science, 1978.

Doll, R. and R. Peto. "The cause of cancer: quantitative estimates of avoidable risks of cancer in the United States today." Journal of the National Cancer Institute, 1981.

Felton, J.S., E. Fultz, F.A. Dolbeare, and M.G. Knize. "Effect of Microwave pretreatment on heterocyclic aromatic amine mutagens/carcinogens in fried beef patties." Food and Chemical Toxicology, 1994.

"Food Mutagens: Mutagenic Activity, DNA Mechanisms, and Cancer Risk." Science \& Technology Review, September 1995.

Gross, G.A. "Simple methods for quantifying mutagenic heterocyclic aromatic amines in food products." Carcinogenesis, 1990.

Hrudey, S. and D. Krewsk. "Is there a safe level of exposure to a carcinogen?" Environmental Science \& Technology, 1995

Jagerstad, M., K. Skog, S. Grivas, and K. Olsson. "Formation of heterocyclic amines using model systems." Mutation Research, 1991.

Knize, M.G. et al. "Effect of cooking time and temperature on the heterocyclic amine content of fried beef patties." Food and Chemical Toxicology, 1994.

McCann, J., E. Choi, E. Yamasaki, and B.N. Ames. "Detection of carcinogens as mutagens in the Salmonella/microsome test: Assay of 300 chemicals." Food and Chemical Toxicology, 1975.

"Prevention of Cancer"; Technical Report Series 276; World Health Organization: Geneva, 1964.

Sflomos, C., R. Papadopoulou, and K. Athanasiou. "Temperature and time effects on mutagen production in cooked lamb meat." Mutagenesis, 1989.

Sugimura, T. et al. "Mutagen-Carcinogens in Foods with Special Reference to Highly Mutagenic Pyrolytic Products in Broiled Foods." Origins of Human Cancer, 1977. 


\section{Appendix A: Marinade Recipes}

\section{Japanese Teriyaki Marinade}

*Taken from High-Flavor Low-Fat Cooking by Steven Raichlen (Camden House Publishing, 1992).

$1 / 4$ cup soy sauce

1 Tbs. minced fresh ginger

3 cloves garlic, minced (1 Tbsp.)

3 scallions, finely chopped

$1 / 4$ cup white rice wine

1 Tbsp. sesame oil

2 Tbsp. maple syrup

\section{American Southern Marinade}

* Taken from Good Parties by Lee Bailey

1/2 cup packed brown sugar

3 medium garlic cloves, crushed

$11 / 2$ tsp. salt

3 Tbsp. grainy mustard

$1 / 4$ cup cider vinegar

1 lime (juice)

$1 / 2$ large lemon (juice)

6 Tbsp. olive oil

Black pepper

Indian Tandoori Marinade

* Taken from Cuisines of the World by Ann Stalt

5 Tbsp. plain yogurt

1 dsp. lime juice

2 tsp. vinegar

1 tsp. salt

4 drops tomato coloring

1 Tbsp. melted butter

6 cloves garlic

$2 \mathrm{~cm}$ piece fresh ginger root

$1 / 2$ tsp. cumin seeds

$11 / 2$ tsp. coriander seeds

6 dry red chillies

\section{Single-ingredient Marinades}

Soy Sauce (representing Teriyaki Marinade) Kikkoman Dark Soy Sauce (undiluted)

Yogurt (representing Tandoori Marinade)

"Plain" flavored Low fat Yogurt (2\% Milkfat)

Sunnyside Farms Brand

Grade A Pasteurized 


\section{Brown Sugar (representing Southern Marinade)}

1/2 cup firmly packed brown sugar (Sunnyside Farms Brand)

$50 \mathrm{ml}$ distilled water 
